NEVADA TEST SITE

2009 WASTE MANAGEMENT MONITORING REPORT

AREA 3 AND AREA 5 RADIOACTIVE WASTE

MANAGEMENT SITES

June 2010

Prepared for:

U.S. Department of Energy

National Nuclear Security Administration

Nevada Site Office

Prepared by:

National Security Technologies, LLC

Las Vegas, Nevada 


\section{DISCLAIMER}

Reference herein to any specific commercial product, process, or service by trade name, trademark, manufacturer, or otherwise does not necessarily constitute or imply its endorsement, recommendation, or favoring by the United States Government or any agency thereof.

Available for sale to the public, in paper, from:

U.S. Department of Commerce

National Technical Information Service

5301 Shawnee Road

Alexandria, VA 22312

Phone: 800.553.6847

Fax: 703.605.6900

E-mail: orders@ntis.gov

Online Ordering: http://www.ntis.gov/help/ordermethods.aspx

Available electronically at http://www.osti.gov/bridge

Available for a processing fee to the U.S. Department of Energy and its contractors, in paper, from:

U.S. Department of Energy

Office of Scientific and Technical Information

P.O. Box 62

Oak Ridge, TN 37831-0062

Phone: 865.576.8401

Fax: 865.576.5728 


\title{
NEVADA TEST SITE 2009 WASTE MANAGEMENT MONITORING REPORT AREA 3 AND AREA 5 RADIOACTIVE WASTE MANAGEMENT SITES
}

\author{
June 2010 \\ Prepared for: \\ U.S. Department of Energy \\ National Nuclear Security Administration \\ Nevada Site Office \\ Prepared by: \\ National Security Technologies, LLC \\ Las Vegas, Nevada
}


THIS PAGE INTENTIONALLY LEFT BLANK 


\section{EXECUTIVE SUMMARY}

Environmental monitoring data were collected at and around the Area 3 and Area 5 Radioactive Waste Management Sites (RWMSs) at the Nevada Test Site (NTS). These data are associated with radiation exposure, air, groundwater, meteorology, vadose zone, subsidence, and biota. This report summarizes the 2009 environmental data to provide an overall evaluation of RWMS performance and to support environmental compliance and performance assessment (PA) activities. Some of these data (e.g., radiation exposure, air, and groundwater) are presented in other reports (National Security Technologies, LLC, 2009; 2010; Warren and Grossman, 2009).

Direct radiation monitoring data indicate exposure levels at the RWMSs are within the range of background levels measured at the NTS. Air monitoring data at the Area 3 and Area 5 RWMSs indicate that tritium concentrations are slightly above background levels. All gamma spectroscopy results for air particulates collected at the Area 3 and Area 5 RWMS were below the minimum detectable concentrations, and concentrations of americium and plutonium are only slightly above detection limits. The measured levels of radionuclides in air particulates and moisture are below derived concentration guides for these radionuclides. Radon flux from waste covers is well below regulatory limits. Groundwater monitoring data indicate that the groundwater in the uppermost aquifer beneath the Area 5 RWMS is not impacted by facility operations. The 87.6 millimeters $(\mathrm{mm})$ (3.45 inches [in.]) of precipitation at the Area 3 RWMS during 2009 is 43 percent below the average of $152.4 \mathrm{~mm}$ (6.00 in.), and the $62.7 \mathrm{~mm}$ (2.47 in.) of precipitation at the Area 5 RWMS during 2009 is 49 percent below the average of $122.5 \mathrm{~mm}$ (4.82 in.). Soil-gas tritium monitoring at borehole GCD-05 continues to show slow subsurface migration consistent with previous results. Water balance measurements indicate that evapotranspiration from the vegetated weighing lysimeter dries the soil and prevents downward percolation of precipitation more effectively than evaporation from the bare-soil weighing lysimeter. Data from the automated vadose zone monitoring system for the operational waste pit covers show that moisture from precipitation did not percolate below 90 centimeters $(\mathrm{cm})(3$ feet [ft]) before being removed by evaporation. Moisture from precipitation did not percolate below $30 \mathrm{~cm}(1 \mathrm{ft})$ in the vegetated final mono-layer cover on the U-3ax/bl disposal unit at the Area 3 RWMS before being removed by evapotranspiration. During 2009, there was no drainage through 2.4 meters $(8 \mathrm{ft}$ ) of soil from the Area 3 drainage lysimeters that received only natural precipitation or were vegetated, but water drained from the bare-soil Area 3 drainage lysimeter that received 3 times natural precipitation. Elevated tritium levels in plants and animals sampled from the Area 3 and Area 5 RWMSs show tritium uptake by the biota, but the low levels of other radionuclides do not indicate that there has been biota intrusion into the waste.

All 2009 monitoring data indicate that the Area 3 and Area 5 RWMSs are performing within expectations of the model and parameter assumptions for the facility PAs. 
THIS PAGE INTENTIONALLY LEFT BLANK 


\section{TABLE OF CONTENTS}

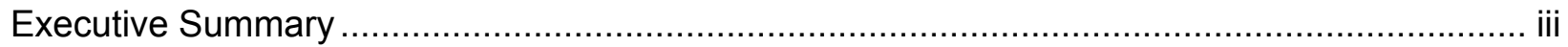

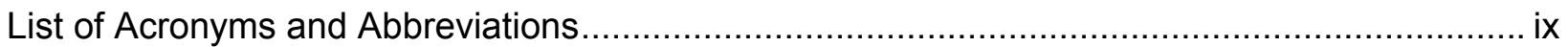

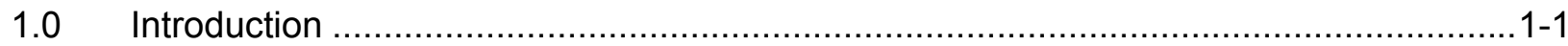

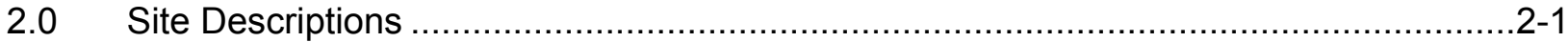

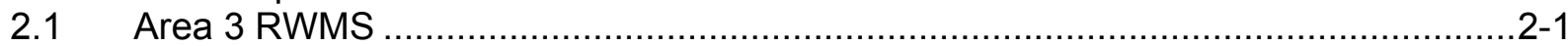

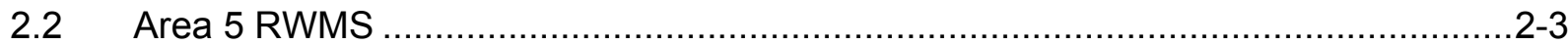

2.3 Hydrologic Conceptual Model of the Area 3 and Area 5 RWMS ..............................

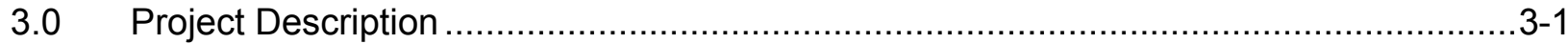

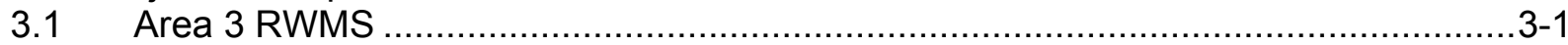

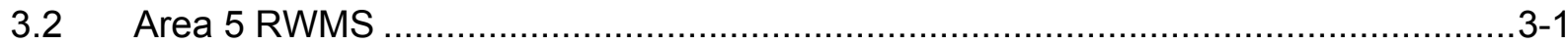

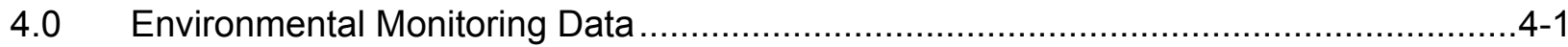

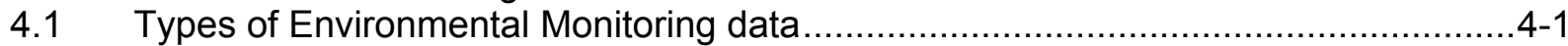

$4.2 \quad$ Radiation Exposure Data .............................................................................

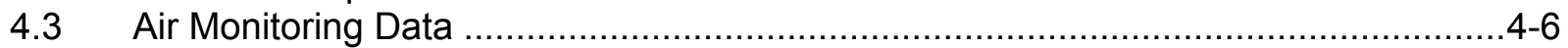

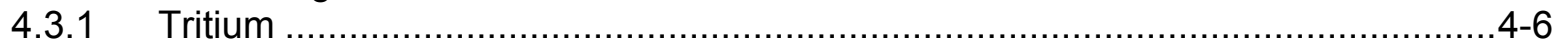

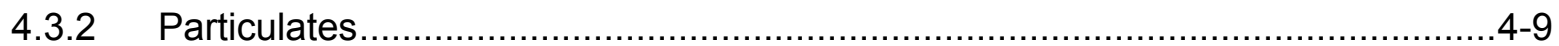

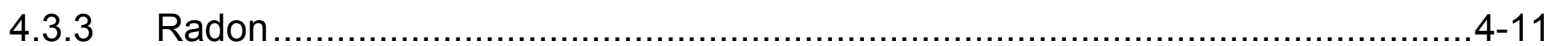

4.4 Groundwater Monitoring Data .............................................................. $4-13$

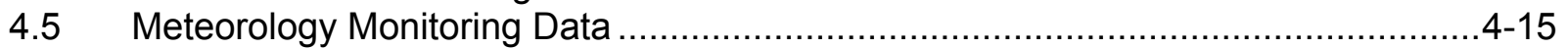

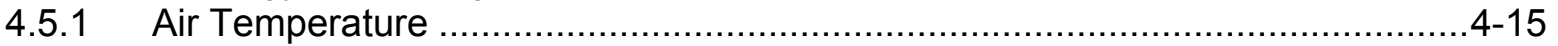

4.5.2 Relative Humidity .................................................................................

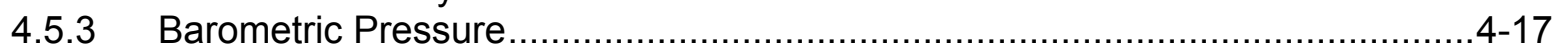

4.5.4 Wind Speed and Wind Direction ........................................................... 4

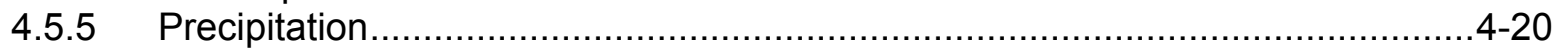

4.5.6 Reference Evapotranspiration ..........................................................

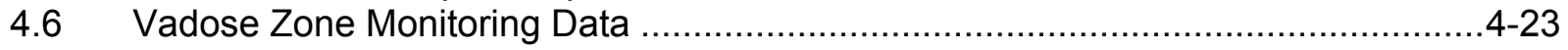

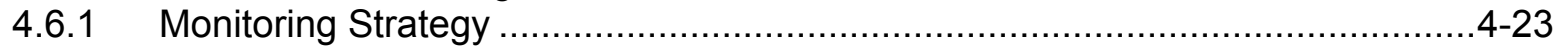

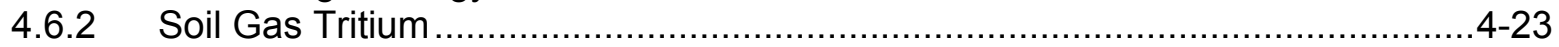

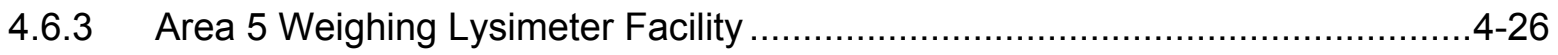

4.6.4 Automated Waste Cover Monitoring System ........................................... 4-28

4.6.5 Area 3 Drainage Lysimeter Facility ...................................................... $4-32$

4.7 Waste Cover Subsidence ...........................................................................

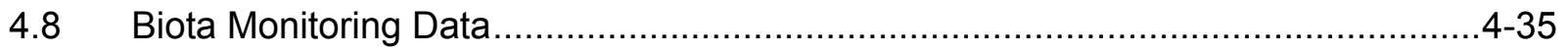

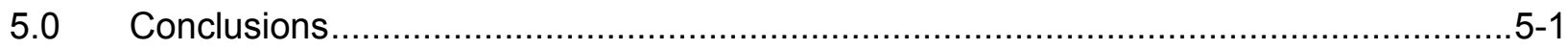

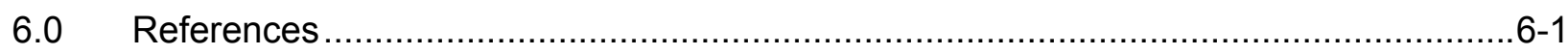

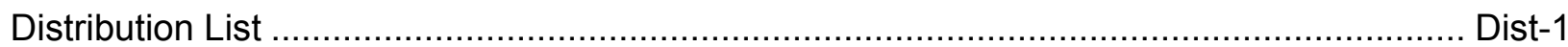




\section{LIST OF FIGURES}

Figure 2-1. Location of the Area 3 and Area 5 RWMSs.................................................2

Figure 2-2 Vadose Zone Conceptual Models of the Area 3 and Area 5 RWMSs ..................2-5

Figure 3-1 Monitoring Locations at the Area 3 RWMS ...................................................

Figure 3-2 Monitoring Locations at the Area 5 RWMS .................................................. $3-2$

Figure 3-3 Pilot Wells, Weighing Lysimeters, and Air Monitoring at the Area 5 RWMS ..........3-3

Figure 4-1 Annual Radiation Exposure Rates at the Area 3 RWMS ..................................4-4

Figure 4-2 Quarterly Average Daily Exposure Rates at the Area 3 RWMS and NTS Background

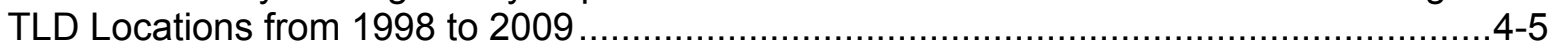

Figure 4-3 Quarterly Average Daily Exposure Rates at the Area 5 RWMS and NTS Background

TLD Locations from 1998 to 2009 ............................................................................ 4-5

Figure 4-4 Tritium Concentration in Air at the Area 3 and Area 5 RWMSs during 2009..........4-7

Figure 4-5 Silica Gel Packet and Tin Used to Collect Surface Evaporation ............................4-7

Figure 4-6 Tritium in Surface Soil Moisture at the Area 5 RWMS .......................................4-8

Figure 4-7 Concentration of ${ }^{241} \mathrm{Am}$ in Air at the Area 3 and Area 5 RWMSs during 2009........4-9

Figure 4-8 Concentration of ${ }^{238} \mathrm{Pu}$ in Air at the Area 3 and Area 5 RWMSs during 2009.......4-10

Figure 4-9 Concentration of ${ }^{239+240} \mathrm{Pu}$ in Air at the Area 3 and Area 5 RWMSs during 2009 ..4-10

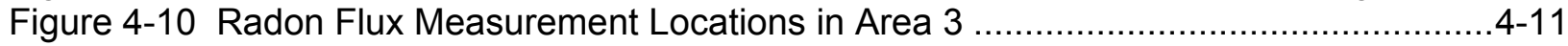

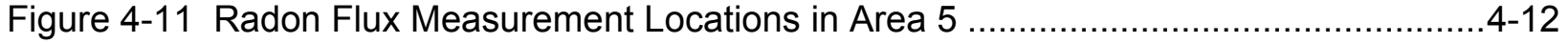

Figure 4-12 Radon Flux Results from 2000 through 2009 ...........................................4-12

Figure 4-13 Groundwater Elevation at the Three Area 5 RWMS Pilot Wells .......................4-14

Figure 4-14 Daily Maximum and Minimum Temperature at the Area 3 and Area 5 RWMSs..4-15

Figure 4-15 Daily Average Relative Humidity at the Area 3 and Area 5 RWMSs .................4-16

Figure 4-16 Average Barometric Pressure at the Area 3 and Area 5 RWMSs ....................4-17

Figure 4-17 Daily $3 \mathrm{~m}$ Wind Speed at the Area 3 RWMS ................................................4-18

Figure 4-18 Daily $3 \mathrm{~m}$ Wind Speed at the Area 5 RWMS ...........................................4-18

Figure 4-19 Wind Rose Diagram for the Area 3 RWMS ...............................................4-19

Figure 4-20 Wind Rose Diagram for the Area 5 RWMS ............................................4-19

Figure 4-21 Daily Precipitation at the Area 3 RWMS ....................................................4-21

Figure 4-22 Daily Precipitation at the Area 5 RWMS ..................................................4-21

Figure 4-23 Historical Precipitation Record for Buster-Jangle $Y$ and the Area 3 RWMS.......4-22

Figure 4-24 Historical Precipitation Record for Well 5B and the Area 5 RWMS ..................4-22

Figure 4-25 Soil-Gas Tritium Concentration Depth Profiles at GCD-05 ............................4-24

Figure 4-26 Soil-Gas Tritium Concentration for Each Depth at GCD-05 ..........................4-25

Figure 4-27 Weighing Lysimeter Data from March 1994 to December 2009.....................4-27

Figure 4-28 Precipitation, ET, E, and Storage for the Weighing Lysimeters during 2009......4-27

Figure 4-29 Monthly Precipitation, E, and ET during 2009 ............................................4-28

Figure 4-30 Soil Water Content in the Pit 5 Floor ........................................................4-29

Figure 4-31 Soil Water Content in the Pit 3 Waste Cover at Pit 3S ..................................4-29

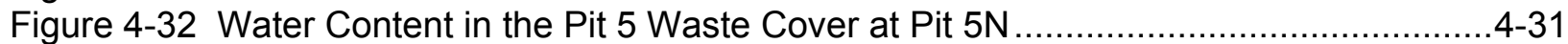

Figure 4-33 Soil Water Content in the U-3ax/bl Cover...................................................4-31

Figure 4-34 Cumulative Drainage from the Drainage Lysimeters ...................................4-34

Figure 4-35 Soil Water Storage in the Drainage Lysimeters...........................................4-34

Figure 4-36 Area 3 RWMS Biota and Soil Sample Locations and Tritium Results (pCi/L) .....4-37

Figure 4-37 Area 5 RWMS Biota and Soil Sample Locations and Tritium Results (pCi/L) .....4-37

Figure 4-38 Tritium Concentrations in RWMS Vegetation, 1999-2009 .............................4-38

Figure 4-39 Tritium Concentrations in RWMS Animals, 2005-2009................................4-38 


\section{LIST OF TABLES}

Table 1 Investigation Levels and Results from 2009 Groundwater Monitoring .....................4-13

Table 2 Area 3 Drainage Lysimeter Treatments in 2009 .............................................4-33

Table 3 Area 3 Drainage Lysimeters Percent Cover ................................................. $4-33$

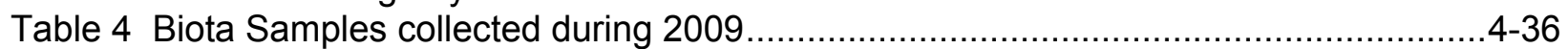

Table 5 Radionuclide Results for Plant Samples collected in 2009 ..................................4-39

Table 6 Radionuclide Results for Animal Samples collected in 2009 ..............................4-40

Table 7 Radionuclide Results for Soil Samples collected in 2009 .................................4-41 
THIS PAGE INTENTIONALLY LEFT BLANK 


\section{LIST OF ACRONYMS AND ABBREVIATIONS}

AGL

above ground level

Am

Americium

AMSL above mean sea level

ARL/SORD

Air Resources Laboratory, Special Operations and Research Division

BJY

Buster-Jangle $Y$

$\mathrm{BN}$

Bechtel Nevada

${ }^{\circ} \mathrm{C}$

$\mathrm{C}$

CAU

CFR

$\mathrm{Ci}$

$\mathrm{cm}$

Cs

degrees Celsius

carbon

Corrective Action Unit

Code of Federal Regulations

curie

centimeter(s)

Cesium

DCG

DOE

Derived Concentration Guide

U.S. Department of Energy

E

ET

$\mathrm{ET}_{\text {ref }}$

evaporation

evapotranspiration

reference evapotranspiration

${ }^{\circ} \mathrm{F}$

$\mathrm{ft}$

$\mathrm{ft}^{3}$

degrees Fahrenheit

foot; feet

cubic feet

GCD

greater confinement disposal

IL

investigation level

in. inch(es)

$\mathrm{km} \quad$ kilometer(s)

$\mathrm{kPa} \quad$ kilopascal(s)

LLW low-level waste

$\mu \mathrm{Ci} / \mathrm{m}^{3} \quad$ microcurie(s) per cubic meter

$\mu g / L$

$\mathrm{m}$

$\mathrm{m}^{3}$

$\mathrm{m} / \mathrm{s}$

MDC

MEDA

$\mathrm{mg} / \mathrm{L}$

$\mathrm{mi}$

microgram(s) per liter

meter(s)

cubic meter(s)

meter(s) per second(s)

minimum detectable concentration

Meteorological Data Acquisition

milligram(s) per liter

mile(s)

millimeter(s)

$\mathrm{mm}$

millimho(s) per centimeter 


\begin{tabular}{|c|c|}
\hline $\begin{array}{l}\mathrm{mph} \\
\mathrm{mR} \\
\mathrm{mR} / \text { day } \\
\mathrm{mR} / \mathrm{yr} \\
\mathrm{mrem} \\
\mathrm{mrem} / \mathrm{yr}\end{array}$ & $\begin{array}{l}\text { mile(s) per hour } \\
\text { milliroentgen(s) } \\
\text { milliroentgen(s) per day } \\
\text { milliroentgen(s) per year } \\
\text { millirem(s) } \\
\text { millirem(s) per year }\end{array}$ \\
\hline $\begin{array}{l}\text { NSTec } \\
\text { NTS }\end{array}$ & $\begin{array}{l}\text { National Security Technologies, LLC } \\
\text { Nevada Test Site }\end{array}$ \\
\hline $\begin{array}{l}\mathrm{PA} \\
\mathrm{pCi} / \mathrm{L} \\
\mathrm{pCi} / \mathrm{m}^{3} \\
\mathrm{pCi} / \mathrm{m}^{2} / \mathrm{s} \\
\mathrm{PSI} \\
\mathrm{PST} \\
\mathrm{Pu}\end{array}$ & $\begin{array}{l}\text { Performance Assessment } \\
\text { picocuries per liter } \\
\text { picocuries per cubic meter } \\
\text { picocuries per square meter per second } \\
\text { pounds per square inch } \\
\text { pacific standard time } \\
\text { Plutonium }\end{array}$ \\
\hline $\begin{array}{l}\text { RREMP } \\
\text { RWMS }\end{array}$ & $\begin{array}{l}\text { Routine Radiological Environmental Monitoring Plan } \\
\text { Radioactive Waste Management Site }\end{array}$ \\
\hline $\begin{array}{l}\text { SC } \\
\text { Sr }\end{array}$ & $\begin{array}{l}\text { specific conductance } \\
\text { strontium }\end{array}$ \\
\hline $\begin{array}{l}\text { TDR } \\
\text { Te } \\
\text { TLD } \\
\text { TOC } \\
\text { TOX }\end{array}$ & $\begin{array}{l}\text { time-domain reflectometry } \\
\text { technetium } \\
\text { thermoluminescent dosimeter } \\
\text { total organic carbon } \\
\text { total organic halides }\end{array}$ \\
\hline VVV & volumetric water content \\
\hline
\end{tabular}




\subsection{INTRODUCTION}

This document summarizes the calendar year 2009 waste management environmental monitoring data for the Area 3 and Area 5 Radioactive Waste Management Sites (RWMSs). Characterization reports for the Area 3 RWMS (National Security Technologies, LLC [NSTec], 2007) and the Area 5 RWMS (Bechtel Nevada [BN], 2006) provide descriptions of each RWMS including location, setting, waste disposal operations, and monitoring programs. These reports also provide brief summaries of characterization and monitoring data. The Integrated Closure and Monitoring Plan for the Area 3 and Area 5 Radioactive Waste Management Sites at the Nevada Test Site (BN, 2005c) and the Closure Plan for the Area 5 Radioactive Waste Management Site at the Nevada Test Site (NSTec, 2008) identify the regulatory requirements and describe the intended approach for closing and monitoring the RWMSs after waste disposal is finished. This report summarizes environmental data, as briefly defined below.

- Direct radiation monitoring conducted to confirm that RWMS activities do not result in significant exposure above background levels.

- Air monitoring conducted to confirm that RWMS activities do not result in significant radionuclide concentrations above background levels and confirm compliance with National Emission Standards for Hazardous Air Pollutants.

- Groundwater monitoring conducted, as required by U.S. Environmental Protection Agency regulations and U.S. Department of Energy (DOE) orders, to assess the water quality of the aquifer beneath the Area 5 RWMS and to confirm that Area 5 RWMS activities are not affecting the aquifer.

- Vadose zone monitoring conducted to assess the water balance at the RWMSs, confirm the assumptions made in performance assessments (PAs) (including no downward pathway), and evaluate the performance of operational monolayer-evapotranspirative waste covers.

- Soil-gas monitoring for tritium conducted to evaluate tritium movement at waste containment cell GCD-05.

- Biota monitoring for tritium and other radionuclides conducted to evaluate the upward pathway through the waste covers.

- Subsidence monitoring conducted to ensure that subsidence features are repaired to prevent the development of preferential pathways through the covers.

These data are collected by NSTec, as required by various DOE orders and requirements from the Code of Federal Regulations (CFR). For a detailed description of these regulatory drivers, refer to the Integrated Closure and Monitoring Plan (BN, 2005c) and the Area 5 RWMS Closure Plan (NSTec, 2008). These regulatory drivers exist to mitigate risk to the public and environment and include the following:

- DOE O 435.1, "Radioactive Waste Management"

- DOE O 450.1A, "Environmental Protection Program"

- DOE O 5400.5, "Radiation Protection of the Public and the Environment"

- 40 CFR 61, "National Emission Standards for Hazardous Air Pollutants" 
- 40 CFR 264, "Standards for Owners and Operators of Hazardous Waste Treatment, Storage, and Disposal Facilities"

- 40 CFR 265, "Interim Status Standards for Owners and Operators of Hazardous Waste Treatment, Storage, and Disposal Facilities"

Environmental monitoring data are collected and analyzed as described in Quality Assurance, Analysis, and Sampling Plans, which can be found in the Nevada Test Site Routine Radiological Environmental Monitoring Plan (RREMP) (BN, 2003). The RREMP was written with a Data Quality Objectives-driven process to identify what and how technically defensible environmental monitoring data are collected. 


\subsection{SITE DESCRIPTIONS}

\section{$2.1 \quad$ AREA 3 RWMS}

The Area 3 RWMS is located on Yucca Flat within the Nevada Test Site (NTS). Yucca Flat is an elongated, sediment-filled basin that trends roughly north-south; the long axis extends approximately 27 kilometers $(\mathrm{km})(17$ miles [mi]), and the short axis extends approximately $16 \mathrm{~km}(10 \mathrm{mi})$. Yucca Flat is bound by Quartzite Ridge and Rainier Mesa on the north, the Halfpint Range on the east, the Massachusetts Mountains and CP Hills on the south, and Mine Mountain and the Eleana Range on the west (Figure 2-1). The Yucca Flat basin slopes from the north at an elevation of approximately 1,402 meters $(\mathrm{m})(4,600$ feet [ft]) above mean sea level (AMSL) to the south toward Yucca playa, with the lowest part of the basin at an elevation of approximately 1,189 $\mathrm{m}$ (3,900 ft) AMSL. The Area 3 RWMS elevation is 1,223 $\mathrm{m}(4,012 \mathrm{ft})$. Yucca Flat was one of several primary underground nuclear test areas, and much of the length of the valley is marked with subsidence craters (NSTec, 2007).

The unsaturated zone at the Area 3 RWMS is estimated to be approximately $488 \mathrm{~m}(1,600 \mathrm{ft})$ thick (BN, 1998), and the water table is assumed to occur in Tertiary tuff. The alluvium thickness is estimated between 370 and $460 \mathrm{~m}$ (1,200 and 1,500 ft) (BN, 2005b).

Based on a 21-year record from 1981 to 2001 at location Buster-Jangle Y (BJY) (4.5 km [2.8 mi] northwest of the Area 3 RWMS), typical daily air temperatures vary from -3 degrees Celsius $\left({ }^{\circ} \mathrm{C}\right)$ (26 degrees Fahrenheit $\left.\left[{ }^{\circ} \mathrm{F}\right]\right)$ to $12^{\circ} \mathrm{C}\left(54^{\circ} \mathrm{F}\right)$ during the winter months of December, January, and February and from $14^{\circ} \mathrm{C}\left(57^{\circ} \mathrm{F}\right)$ to $34^{\circ} \mathrm{C}\left(94^{\circ} \mathrm{F}\right)$ during the summer months of June, July, and August. The average winter temperature is $4^{\circ} \mathrm{C}\left(40^{\circ} \mathrm{F}\right)$ and the average summer temperature is $24^{\circ} \mathrm{C}\left(75^{\circ} \mathrm{F}\right)$. During this 21 -year period, the maximum observed temperature was $43.3^{\circ} \mathrm{C}\left(110^{\circ} \mathrm{F}\right)$ and the minimum observed temperature was $-20^{\circ} \mathrm{C}\left(-4^{\circ} \mathrm{F}\right)$. Average relative humidity is $53 \%$ at 4:00 pacific standard time (PST), $28 \%$ at $10: 00$ PST, $26 \%$ at $16: 00$ PST, and $45 \%$ at $22: 00$ PST. January has the highest relative humidity of $67 \%$ at $4: 00$ PST, $42 \%$ at $10: 00$ PST, $43 \%$ at $16: 00$ PST, and $62 \%$ at $22: 00$ PST. July has the lowest relative humidity of $40 \%$ at 4:00 PST, $19 \%$ at $10: 00$ PST, $17 \%$ at $16: 00$ PST, and $30 \%$ at 22:00 PST. The maximum wind gust observed at BJY during this 21-year period was 29.3 meters per sec $(\mathrm{m} / \mathrm{s})(65.6 \mathrm{miles}$ per hour [mph]) in 1987 (Soule, 2006). The average annual precipitation at BJY during the 49-year period from 1961 through 2009 is 161.6 millimeters $(\mathrm{mm})$ (6.36 inches [in.]). Typically low intensity, longer duration storms occur during the winter, and thunderstorms occur during the late summer. February has the most precipitation and June has the least precipitation (Air Resources Laboratory, Special Operations and Research Division [ARL/SORD], 2010). Annual reference evapotranspiration ( $\mathrm{ET}_{\text {ref }}$ ) at the Area 3 RWMS, calculated using local meteorology data, is approximately 10 times the annual average precipitation (Desotell et al., 2007). 


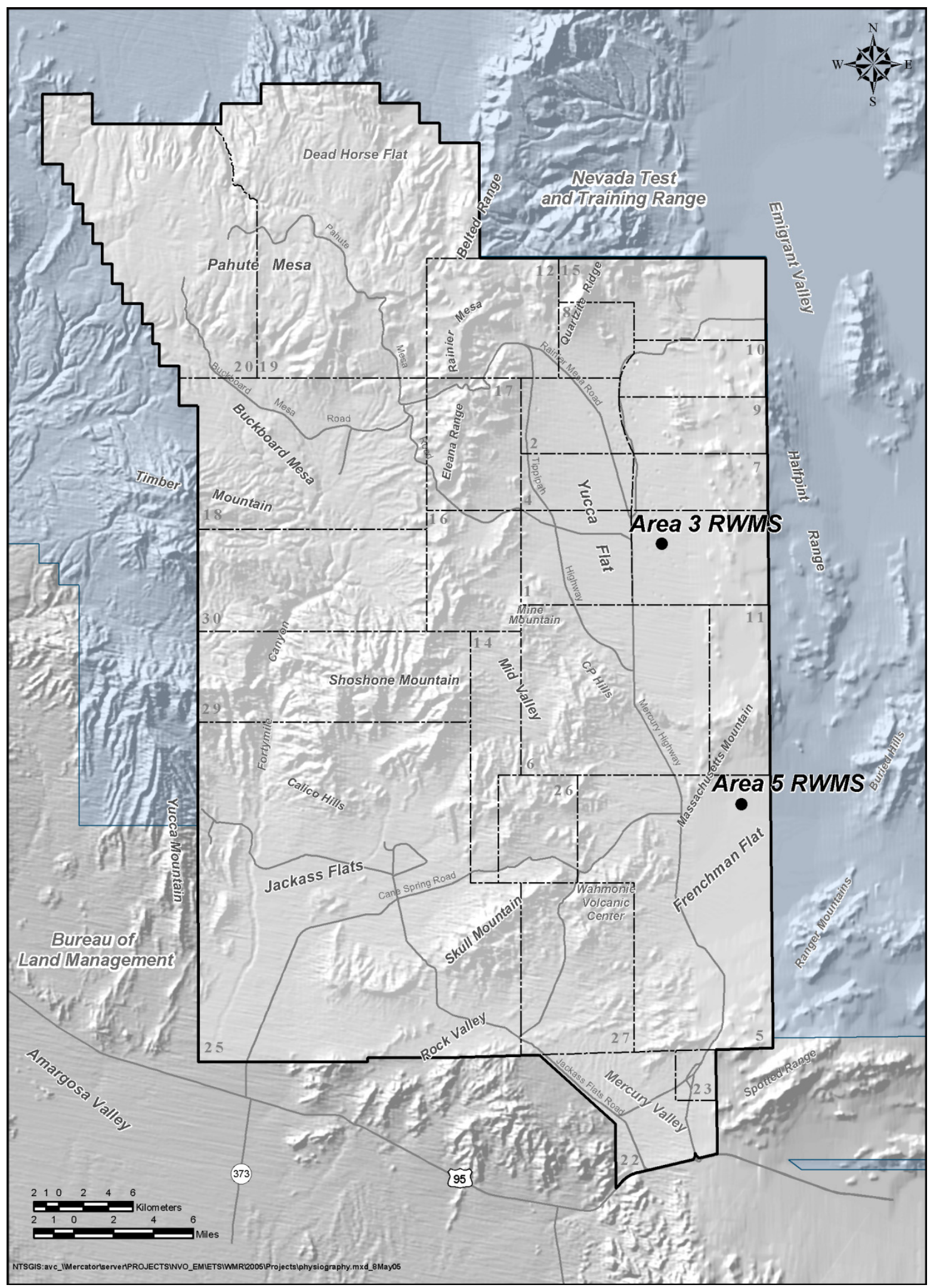

Figure 2-1. Location of the Area 3 and Area 5 RWMSs 


\subsection{AREA 5 RWMS}

The Area 5 RWMS is located on northern Frenchman Flat at the juncture of three coalescing alluvial fan piedmonts (Snyder et al., 1995). Frenchman Flat is a closed intermontane basin located in the southeastern portion of the NTS. Frenchman Flat is bound by the Massachusetts Mountains and the Halfpint Range on the north, the Buried Hills on the east, the Spotted Range on the south, and the Wahmonie Volcanic Center on the west (Figure 2-1). The valley floor slopes gently toward a central playa (BN, 2006). Ground surface elevations range from $938 \mathrm{~m}$ $(3,077 \mathrm{ft})$ AMSL at the playa to over $1,220 \mathrm{~m}(4,003 \mathrm{ft})$ AMSL in the nearby surrounding mountains. The Area 5 RWMS elevation is $962 \mathrm{~m}(3,156 \mathrm{ft})$.

The thickness of the unsaturated zone at the Area 5 RWMS is $235.8 \mathrm{~m} \mathrm{(774} \mathrm{ft)} \mathrm{at} \mathrm{the} \mathrm{southeast}$ corner of the RWMS (Well UE5PW-1), $256.4 \mathrm{~m}$ (841 ft) at the northeast corner (Well UE5PW-2), and $271.5 \mathrm{~m}(891 \mathrm{ft}$ ) to the northwest of the RWMS (Well UE5PW-3). Wells UE5PW-1 and UE5PW-2 penetrate only alluvium, while Well UE5PW-3 encounters tertiary tuff at a depth of approximately $189 \mathrm{~m}$ (620 ft) (BN, 2005a). The water table beneath the Area 5 RWMS is extremely flat with flow velocities of less than $0.1 \mathrm{~m} /$ year $(0.33 \mathrm{ft} / \mathrm{year})$. The average groundwater elevation measured at these wells is $733.7 \mathrm{~m}(2,407 \mathrm{ft})$ AMSL.

Based on a 21-year record from 1981 to 2001 at location Well 5B $(6.4 \mathrm{~km} \mathrm{[4} \mathrm{mi]} \mathrm{south} \mathrm{of} \mathrm{the}$ Area 5 RWMS $)$, typical daily air temperatures vary from $-4^{\circ} \mathrm{C}\left(25^{\circ} \mathrm{F}\right)$ to $14^{\circ} \mathrm{C}\left(57^{\circ} \mathrm{F}\right)$ during the winter months of December, January, and February and from $15^{\circ} \mathrm{C}\left(59^{\circ} \mathrm{F}\right)$ to $37^{\circ} \mathrm{C}\left(99^{\circ} \mathrm{F}\right)$ during the summer months of June, July and August. The average winter temperature is $5^{\circ} \mathrm{C}\left(41^{\circ} \mathrm{f}\right)$ and the average summer temperature is $26^{\circ} \mathrm{C}\left(79^{\circ} \mathrm{F}\right)$. During this 21 -year period the maximum observed temperature was $46^{\circ} \mathrm{C}\left(115^{\circ} \mathrm{F}\right)$ and the minimum observed temperature was $-21^{\circ} \mathrm{C}(-$ $6^{\circ} \mathrm{F}$ ). Average relative humidity is $46 \%$ at $4: 00 \mathrm{PST}, 25 \%$ at $10: 00 \mathrm{PST}, 20 \%$ at $16: 00 \mathrm{PST}$ and $37 \%$ at $22: 00$ PST. January has the highest relative humidity of $65 \%$ at $4: 00$ PST, $46 \%$ at $10: 00$ PST, $34 \%$ at $16: 00$ PST, and $58 \%$ at $22: 00$ PST. June has the lowest relative humidity of $32 \%$ at $4: 00$ PST, $14 \%$ at $10: 00$ PST, $12 \%$ at $16: 00$ PST, and $21 \%$ at $22: 00$ PST. The maximum wind gust observed at Well 5B during this 21 year period was $29.8 \mathrm{~m} / \mathrm{s}(66.7 \mathrm{mph}$ ) in 1988 (Soule, 2006). The average annual precipitation at Well 5B during the 47 year period from 1963 through 2009 is $122.2 \mathrm{~mm}$ (4.81 in.). Typically low intensity, longer duration storms occur during the winter and thunderstorms occur during the late summer. February has the most precipitation and June has the least precipitation (ARL/SORD, 2010). Annual ET ref at the Area 5 RWMS, calculated using local meteorology data, is approximately 13 times the annual average precipitation (Desotell et al., 2006).

Areas 3 and 5 are similar, except for slight differences in air temperature, precipitation, and soil texture. Area 3 receives approximately 30 percent more rainfall than Area 5 , and the annual average temperature at Area 3 is about $2^{\circ} \mathrm{C}\left(4^{\circ} \mathrm{F}\right)$ cooler than at Area 5.

\subsection{HYDROLOGIC CONCEPTUAL MODEL OF THE AREA 3 AND AREA 5 RWMS}

Climate and vegetation strongly control the water movement in the upper few meters of alluvium at both RWMSs. The magnitude and direction of both liquid and vapor fluxes vary seasonally and often daily. Except for periods following precipitation events, water content values in the nearsurface are quite low. Below the dynamic near-surface is a region where relatively steady upward water movement is occurring. In this region of slow upward flow, stable isotope compositions of soil water confirm that evaporation (E) is the dominant process (Tyler et al., 1996). The upward flow region extends to depths from approximately 3 to $49 \mathrm{~m} \mathrm{(10} \mathrm{to} 160 \mathrm{ft}$ ) in Area 3, and from approximately 3 to $40 \mathrm{~m}$ (10 to $131 \mathrm{ft}$ ) in Area 5. Below the upward flow region, water potential 
measurements indicate the existence of a static region. The hydraulic gradient in the static region is zero. The static region is between approximately 49 and $119 \mathrm{~m}$ (160 to $390 \mathrm{ft}$ ) deep in Area 3, and between approximately 40 and 90 m (131 to $295 \mathrm{ft}$ ) deep in Area 5 (Shott et al., 1997; 1998). In the static region, essentially no vertical liquid flow is currently occurring. Below the static region, flow is steady and downward due to gravity (Figure 2-2). Stable isotope compositions of soil water from these depths indicate that infiltration into this zone occurred under cooler past climatic conditions (Tyler et al., 1996). If water were to migrate below the current static zones, movement to the groundwater would be extremely slow due to the low water content of the alluvium. Estimates of travel time to the groundwater (assuming zero upward flux), based on hydraulic characteristics of the alluvium, and assuming that current conditions would still apply, are in excess of 500,000 years in Area 3 (Levitt and Yucel, 2002) and 50,000 years in Area 5 (Shott et al., 1998).

Based on the results of extensive research, field studies, modeling efforts, and monitoring data, which are summarized in the Area 3 and Area 5 PAs (Shott et al., 1997; 1998; Levitt et al., 1999; Levitt and Yucel, 2002; Desotell et al., 2006), groundwater recharge is not occurring under current climatic conditions at the RWMSs. Studies indicate that under bare-soil conditions, such as those found at the operational waste cell covers, some drainage may eventually occur through the waste covers into the waste zone. This drainage is estimated to be about 8 percent of the annual rainfall at Area 5, based on one-dimensional modeling results (Desotell et al., 2006). 


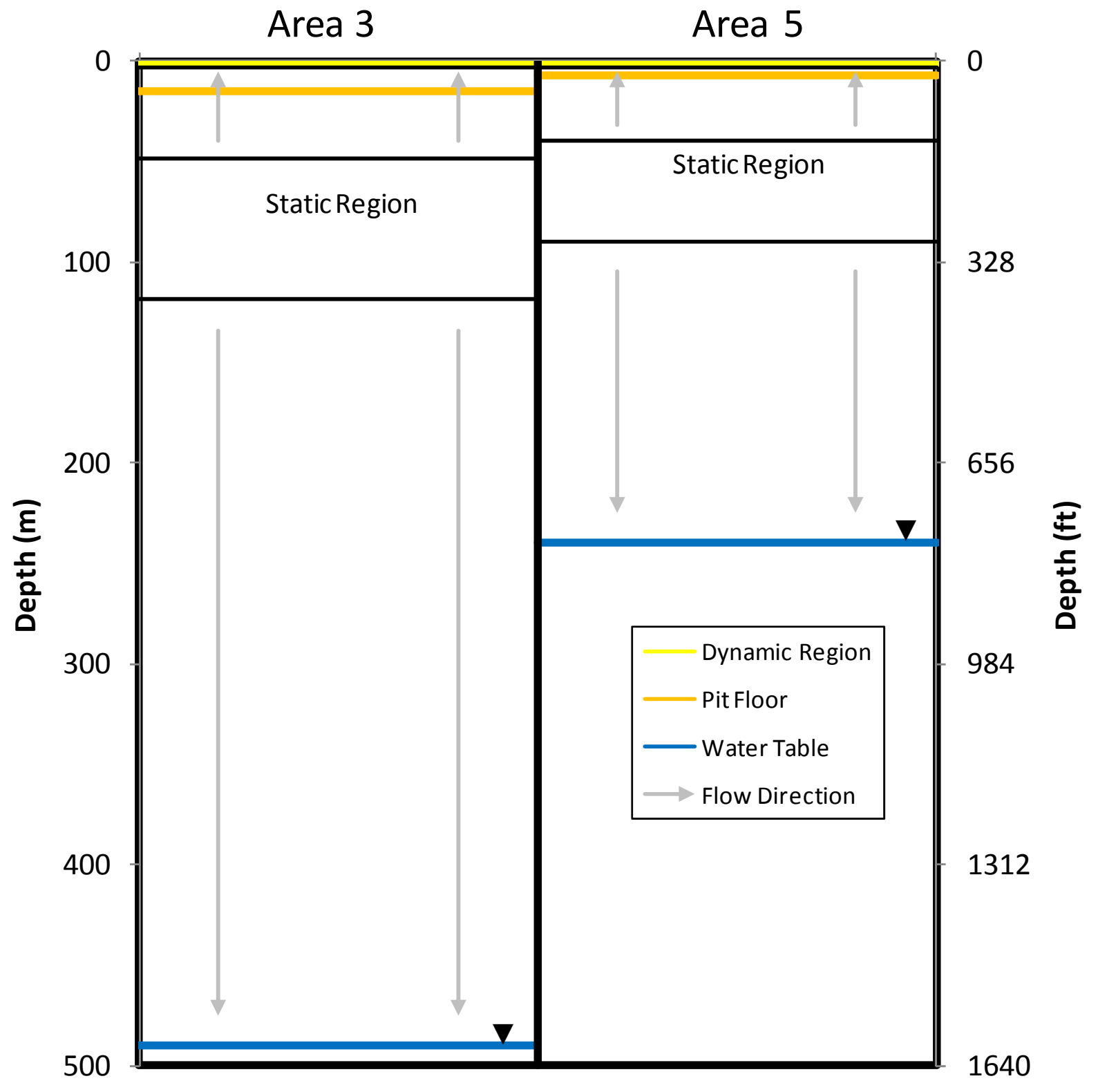

Figure 2-2 Vadose Zone Conceptual Models of the Area 3 and Area 5 RWMSs 
THIS PAGE INTENTIONALLY LEFT BLANK 


\subsection{PROJECT DESCRIPTION}

The Area 3 and Area 5 RWMSs are designed and operated for the disposal of radioactive low-level waste (LLW) and mixed waste that is generated on site (at the NTS), from DOE offsite locations, and from other approved offsite generators.

\subsection{AREA 3 RWMS}

Waste disposal cells within the Area 3 RWMS are subsidence craters resulting from underground nuclear testing. The seven craters within the Area 3 RWMS ranged from 122 to $177 \mathrm{~m} \mathrm{(400} \mathrm{to} 580 \mathrm{ft}$ ) in diameter and from 14 to $32 \mathrm{~m} \mathrm{(46} \mathrm{to} 105 \mathrm{ft}$ ) in depth at the time of formation (Plannerer, 1996). Five of these craters have been used for waste disposal. Disposal in the U-3ax crater began in the late 1960s, and disposal in U-3bl began in 1984. Waste forms consisted primarily of contaminated soil and scrap metal, with some construction debris, equipment, and containerized waste. Craters U-3ax and U-3bl were combined to form the U-3ax/bl disposal unit (Corrective Action Unit [CAU] 110), which is now covered with a

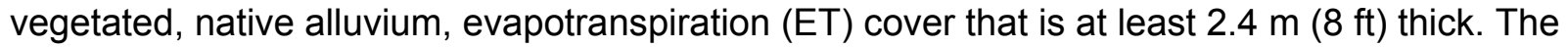
cover was constructed in 2000. For details of the final closure plan of CAU 110, refer to BN (2001). Disposal in the combined unit U-3ah/at began in 1988. Disposal cell U-3ah/at has been used for disposal of bulk LLW from the NTS and approved offsite generators. Crater U-3bh was originally used for disposal of contaminated soils from the Tonopah Test Range in 1997 and has been used since for waste disposal from other approved generators. The remaining two craters are not in use (Figure 3-1). For a detailed description of the facilities at the Area 3 RWMS, refer to Shott et al. (1997) and NSTec (2007). No waste has been disposed at the Area 3 RWMS since 2006.

\subsection{AREA 5 RWMS}

Waste disposal has occurred at the Area 5 RWMS since the early 1960s. The Area 5 RWMS consists of 32 landfill cells (pits and trenches) and 13 greater confinement disposal (GCD) boreholes (Figure 3-2 and Figure 3-3). Some previous documents list fewer landfill cells, but new cells continue to be constructed, and Trench 4 was separated into T04A and T04A1 (BN, 2005c). Pits and trenches range in depth from 4.6 to $15 \mathrm{~m}$ (15 to $48 \mathrm{ft}$ ). The unlined disposal units receive sealed waste containers. Containers are stacked to approximately $1.2 \mathrm{~m}$ ( $4 \mathrm{ft}$ ) below original grade, and soil backfill is pushed over the containers in a single layer to a

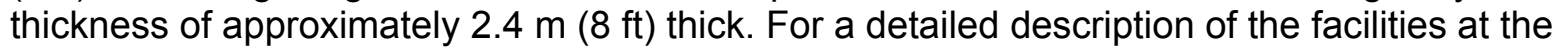
Area 5 RWMS, refer to Shott et al. (1998). For further descriptions of pits, trenches, and GCD boreholes, refer to BN (2005c; 2006) and Cochran et al. (2001).

There are currently nine pits receiving waste at the Area 5 RWMS. The open pits include P03, $\mathrm{P} 06, \mathrm{P} 10, \mathrm{P} 12, \mathrm{P} 13, \mathrm{P} 14, \mathrm{P} 15, \mathrm{P} 16$, and $\mathrm{P} 17$. The only active mixed waste disposal cell is P03. All other active units contain LLW except P06, which contains asbestiform LLW. Waste disposal in $\mathrm{P} 17$ began in 2009. Landfill cells that have been operationally closed to date include all 16 trenches and eight pits. The eight closed pits are P01, P02, P04, P05, P07, P08, P09, and $P 11$. All 13 GCD boreholes are inactive and have not received waste since 1989. Seven GCD boreholes are operationally closed (GCDT, GCD01, GCD02, GCD03, CGD04, GCD05, and GCD10). These boreholes are filled to approximately $20 \mathrm{~m}(65 \mathrm{ft})$ below the surface and backfilled with native soil to the surface. Boreholes GCD06 and GCD07 are partially filled and GCD08, GCD09, GCD11, and GCD12 are empty. 


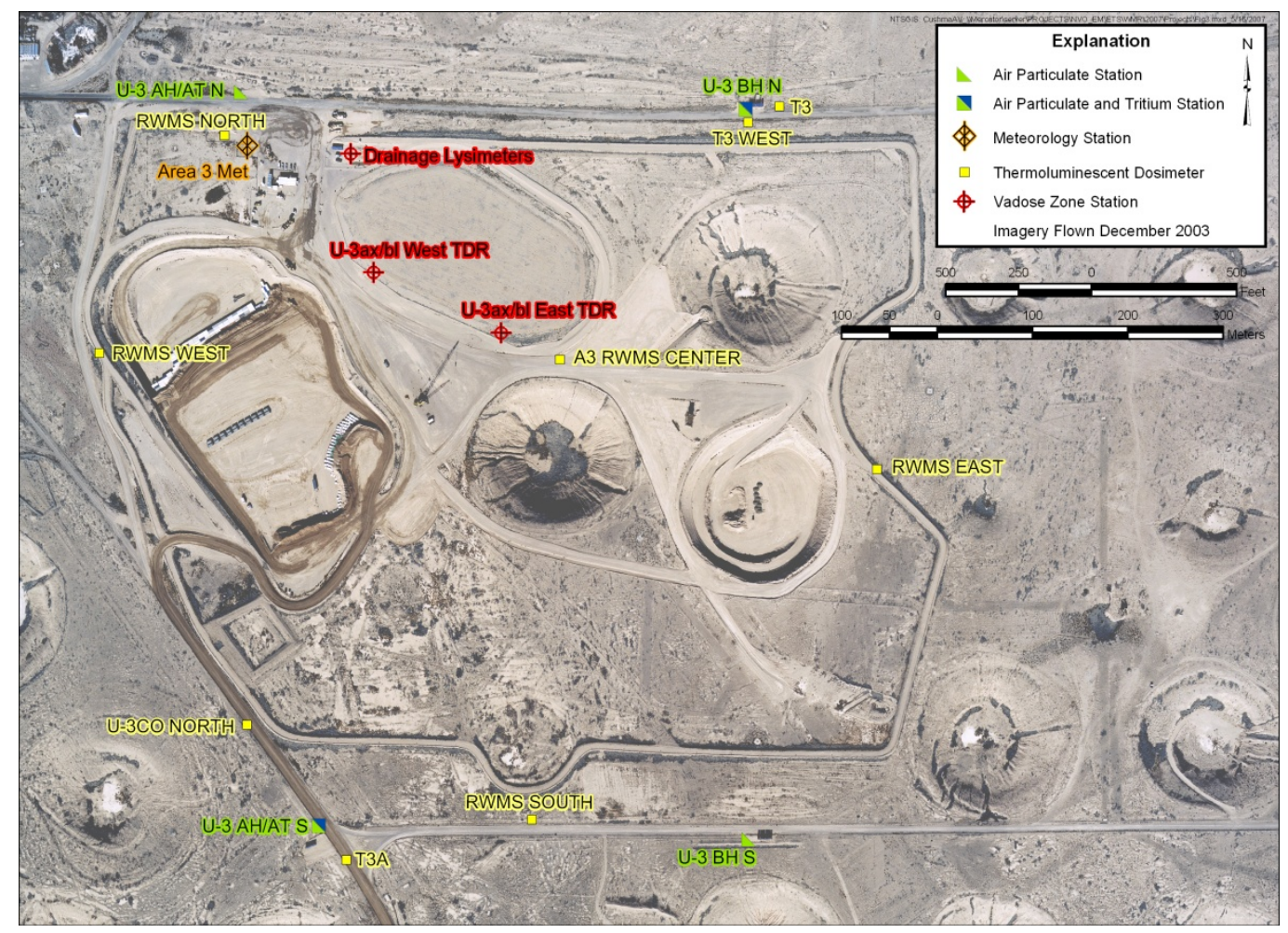

Figure 3-1 Monitoring Locations at the Area 3 RWMS

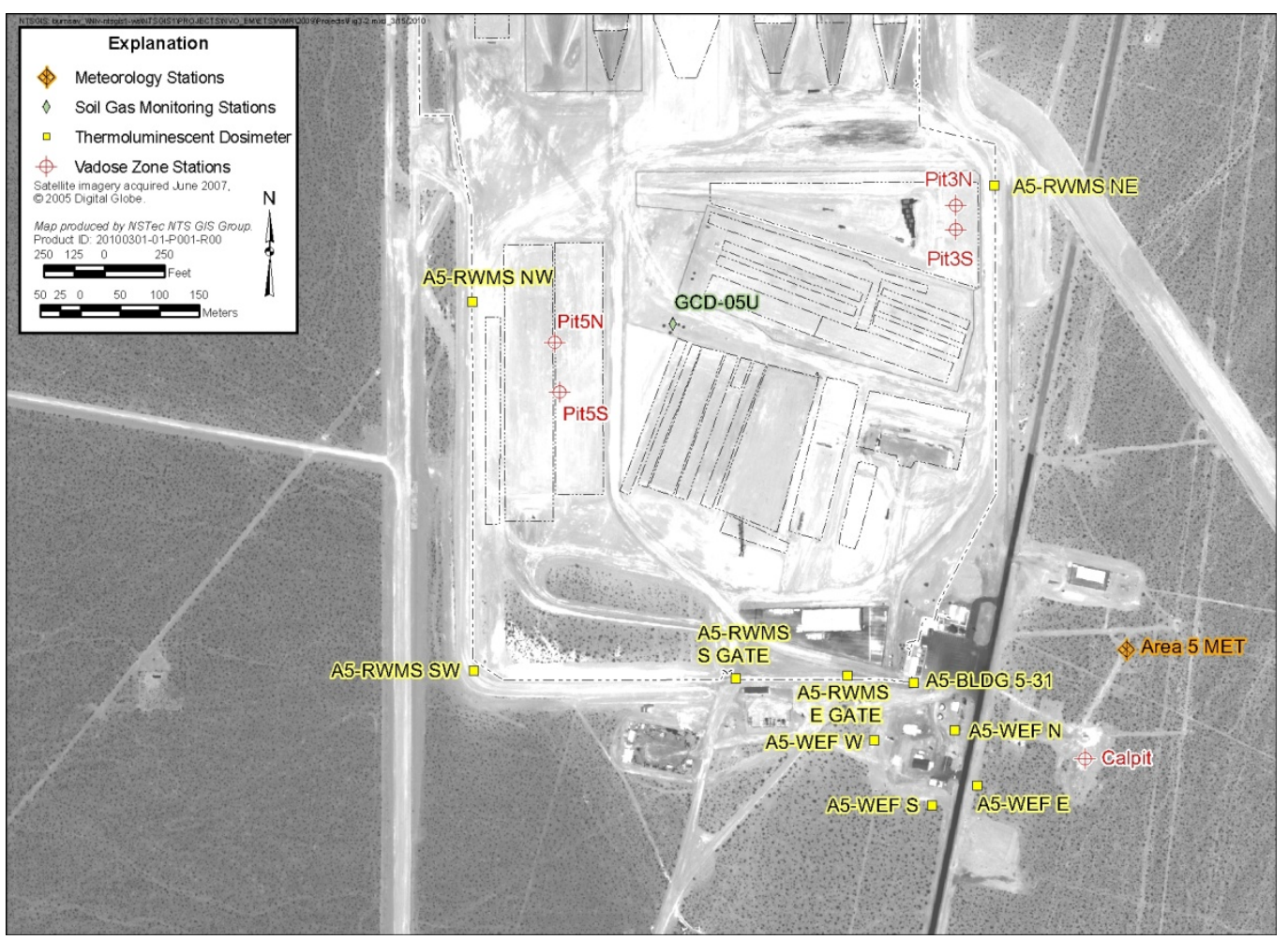

Figure 3-2 Monitoring Locations at the Area 5 RWMS 


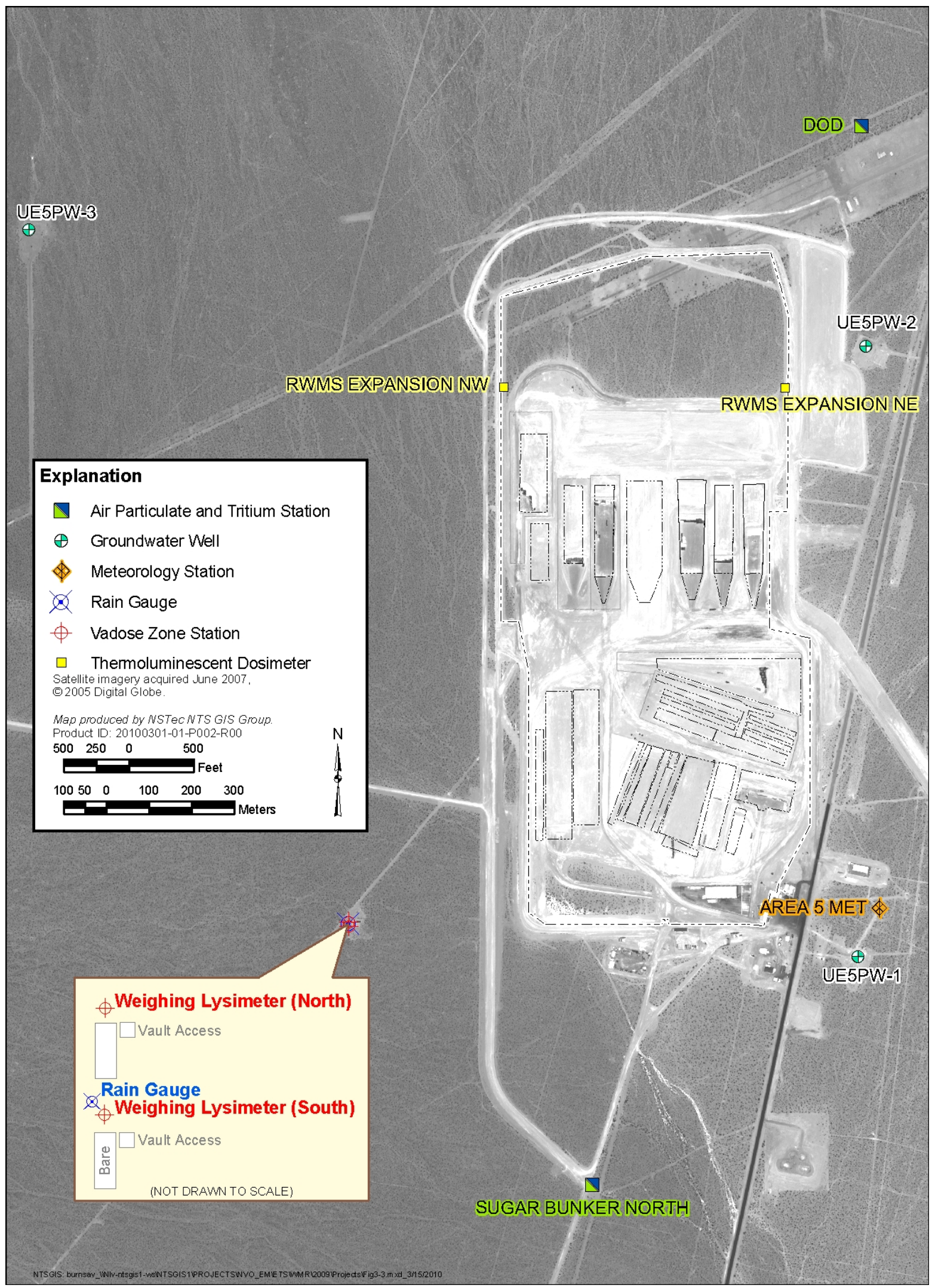

Figure 3-3 Pilot Wells, Weighing Lysimeters, and Air Monitoring at the Area 5 RWMS 
THIS PAGE INTENTIONALLY LEFT BLANK 


\subsection{ENVIRONMENTAL MONITORING DATA}

\subsection{TYPES OF ENVIRONMENTAL MONITORING DATA}

Area 3 RWMS monitoring locations are shown in Figure 3-1, and Area 5 RWMS monitoring locations are shown in Figure 3-2 and Figure 3-3. This report provides a general description and graphical representations of some of these data. Monitoring data currently being collected include:

- Radiation Exposure Data

- Quarterly thermoluminescent dosimeter (TLD) measurements

- Air Monitoring Data

- Weekly Data

- Alpha concentrations

- Beta concentrations

- Biweekly Data

- Tritium concentrations

- Monthly Data

- Gamma concentrations

- Americium (Am) concentrations

- Plutonium (Pu) concentrations

- Periodic radon flux measurements from waste covers

- Groundwater Monitoring Data

- Quarterly Water-Level Measurements

- Semiannual Indicators of Contamination

- $\mathrm{pH}$ (field measurement)

- Specific conductance (SC) (field measurement)

- Total organic carbon (TOC)

- Total organic halides (TOX)

- Tritium

- Semiannual General Water Chemistry Parameters

- Total calcium, iron, magnesium, manganese, potassium, sodium, silicon

- Total sulfate, chloride, fluoride

- Alkalinity

- Biennial RREMP Analyses

- Gross alpha

- Gross beta

- Gamma spectroscopy

- Plutonium $\left({ }^{238} \mathrm{Pu}\right.$ and $\left.{ }^{239+240} \mathrm{Pu}\right)$

- Triennial RREMP Analyses for Specific Radionuclides

- Strontium-90 $\left({ }^{90} \mathrm{Sr}\right)$

- Technetium-99 $\left({ }^{99} \mathrm{Tc}\right)$

- Carbon-14 $\left({ }^{14} \mathrm{C}\right)$ 
- Meteorology Monitoring Data

- Daily Meteorology Data

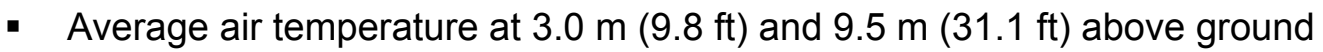
level (AGL)

- Maximum air temperature at $3.0 \mathrm{~m}(9.8 \mathrm{ft})$ and $9.5 \mathrm{~m}(31.1 \mathrm{ft}) \mathrm{AGL}$

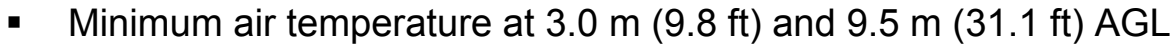

- Average relative humidity at $3.0 \mathrm{~m}(9.8 \mathrm{ft})$ and $9.5 \mathrm{~m}(31.1 \mathrm{ft}) \mathrm{AGL}$

- Maximum relative humidity at $3.0 \mathrm{~m}(9.8 \mathrm{ft})$ and $9.5 \mathrm{~m}(31.1 \mathrm{ft})$ AGL

- Minimum relative humidity at $3.0 \mathrm{~m}(9.8 \mathrm{ft})$ and $9.5 \mathrm{~m}(31.1 \mathrm{ft}) \mathrm{AGL}$

- Average wind speed at $3.0 \mathrm{~m}(9.8 \mathrm{ft})$ and $9.5 \mathrm{~m}(31.1 \mathrm{ft}) \mathrm{AGL}$

- Maximum wind speed at $3.0 \mathrm{~m}(9.8 \mathrm{ft})$ and $9.5 \mathrm{~m}(31.1 \mathrm{ft}) \mathrm{AGL}$

- Average barometric pressure

- Maximum barometric pressure

- Minimum barometric pressure

- Total precipitation

- Hourly Meteorology Data

- Average air temperature at $3.0 \mathrm{~m}(9.8 \mathrm{ft})$ and $9.5 \mathrm{~m}(31.1 \mathrm{ft}) \mathrm{AGL}$

- Average relative humidity at $3.0 \mathrm{~m}(9.8 \mathrm{ft})$ and $9.5 \mathrm{~m}(31.1 \mathrm{ft}) \mathrm{AGL}$

- Average wind speed at $3.0 \mathrm{~m}(9.8 \mathrm{ft})$ and $9.5 \mathrm{~m}(31.1 \mathrm{ft}) \mathrm{AGL}$

- Average wind direction $3.0 \mathrm{~m}$ (9.8 ft) and $9.5 \mathrm{~m}(31.1 \mathrm{ft}) \mathrm{AGL}$

- Average barometric pressure

- Average solar radiation

- Total precipitation

- Vadose Zone Monitoring Data

- Annual Soil Gas Monitoring Data (soil gas tritium concentrations measured at GCD-05 gas sampling ports [nine depths])

- Weighing Lysimeter Data (Area 5)

- Daily and hourly $E$ from the bare-soil weighing lysimeter

- Daily and hourly ET from the vegetated weighing lysimeter

- Daily and hourly precipitation and 5 minute precipitation rates

- Daily soil volumetric water content (VWC) and soil water potential

- Hourly soil temperature with depth

- Drainage Lysimeter Data (Area 3)

- Daily Soil VWC, soil water potential, and water storage with depth

- Hourly temperature with depth

- Daily and hourly drainage from each lysimeter

- Daily Automated Vadose Zone Monitoring System Data

- Soil VWC with depth in waste covers

- Soil VWC beneath waste cells

- Soil water potential with depth in waste covers

- Soil temperature with depth in waste covers 
- Periodic Subsidence Monitoring Data: Locations and descriptions of subsidence features on waste covers

- Biota Monitoring Data: Periodic analysis of plant and animal samples for tritium and other radionuclide concentrations

\subsection{RADIATION EXPOSURE DATA}

The goals of direct radiation monitoring are to assess the external radiation environment, to detect changes in that environment, and to measure gamma radiation levels near potential exposure sites. Performance objectives in DOE O 435.1 require that LLW disposal facilities be sited, designed, operated, maintained, and closed, so it is reasonable to expect a less than 25 millirem per year ( $\mathrm{mrem} / \mathrm{yr}$ ) total effective dose equivalent to representative members of the public from the facility. The effective dose equivalent is from all exposure pathways associated with the facility, but does not include the dose from radon and the background dose. Because the RWMSs are located well within the NTS boundaries, the public does not have access to these areas for significant periods of time. However, exposure rates measured by TLDs located at the RWMSs show the potential dose to a hypothetical person residing year-round at the RWMS.

TLDs (Panasonic UD 814AS) are used to measure ionizing radiation exposure from all sources, including natural and man-made radioactivity. These TLDs have three calcium sulfate elements housed in an air-tight, water-tight, ultraviolet-light-protected case. These elements are used to measure the total exposure rate from penetrating gamma radiation including background. The penetrating gamma radiation makes up the deep dose, which is compared to the $25 \mathrm{mrem} / \mathrm{yr}$ limit when background exposure is subtracted.

Figure 3-1, Figure 3-2, and Figure 3-3 show TLD monitoring locations near the Area 3 and Area 5 RWMSs. At each location, a pair of TLDs is placed at $1 \pm 0.3 \mathrm{~m}$ (28 to $51 \mathrm{in}$.) AGL and are exchanged for analysis on a quarterly basis. TLDs are analyzed using automated TLD readers that are calibrated and maintained by the NSTec Radiological Control Department. Reference TLDs exposed to 100 milliroentgen $(\mathrm{mR})$ from a cesium-137 $\left({ }^{137} \mathrm{Cs}\right)$ radiation source under controlled conditions are used to scale the response of the measurement TLDs. Direct radiation exposure is usually reported in the unit $\mathrm{mR}$, which is a measure of exposure in terms of numbers of ionizations in air. Generally, the dose in human tissue resulting from an exposure from the most common external radionuclides can be approximated by equating a $1 \mathrm{mR}$ exposure with a 1 millirem (mrem) dose.

Between 1952 and 1972, 60 nuclear weapons tests were conducted within $400 \mathrm{~m}(1,312 \mathrm{ft})$ of the Area 3 RWMS boundary. Fourteen of these tests were atmospheric tests, which left radionuclide-contaminated surface soil with elevated radiation exposures across the area. Waste pits in the Area 3 RWMS are subsidence craters from seven subsurface tests that are being filled with LLW. During disposal operations, the waste is covered with clean soil resulting in lower exposures inside the Area 3 RWMS when compared with the average exposures at the Area 3 RWMS fence line or in Area 3 outside the fence line.

Annual radiation exposures in milliroentgen per year (mR/yr) during 2009 at locations inside and near the Area 3 RWMS are shown in Figure 4-1. The Area 3 monitoring locations are (1) inside the Area 3 RWMS (RWMS Center), (2) on the RWMS boundary (RWMS North, RWMS East, RWMS South, RWMS West), and (3) outside the RWMS boundary (T3, T3 West, T3A, and 
U3CO North) (Figure 3-1). The exposures measured inside the Area 3 RWMS and three of four measurements at the boundary are within the range of background exposures. The four TLD locations outside the Area 3 RWMS boundary and RWMS South (boundary location) have higher exposures due to historic aboveground nuclear weapons test locations in close proximity to these locations. Given this, radionuclides in the Area 3 RWMS contributed negligible external exposure to a hypothetical person residing at the Area 3 RWMS. Estimated daily exposure rates in milliroentgen per day (mR/day) from the quarterly exposure rate data at the Area 3 RWMS are presented in Figure 4-2.

Between 1951 and 1971, 25 nuclear weapons tests were conducted within $6.3 \mathrm{~km}$ (3.9 mi) of the Area 5 RWMS. Fifteen of these were atmospheric tests, and nine of the remaining ten tests released radioactivity to the surface. There were no nuclear weapons tests within the boundaries of the Area 5 RWMS. Estimated daily exposure rates from the quarterly exposure data at the Area 5 RWMS are within the range of exposures measured at NTS background locations (Figure 4-3).

Comparisons of 1998 to 2009 direct radiation exposure data using TLDs from the two RWMSs with direct radiation data from NTS background locations indicate that direct radiation exposure at the Area 3 and Area 5 RWMSs is generally low or declining (Figure 4-2 and Figure 4-3).

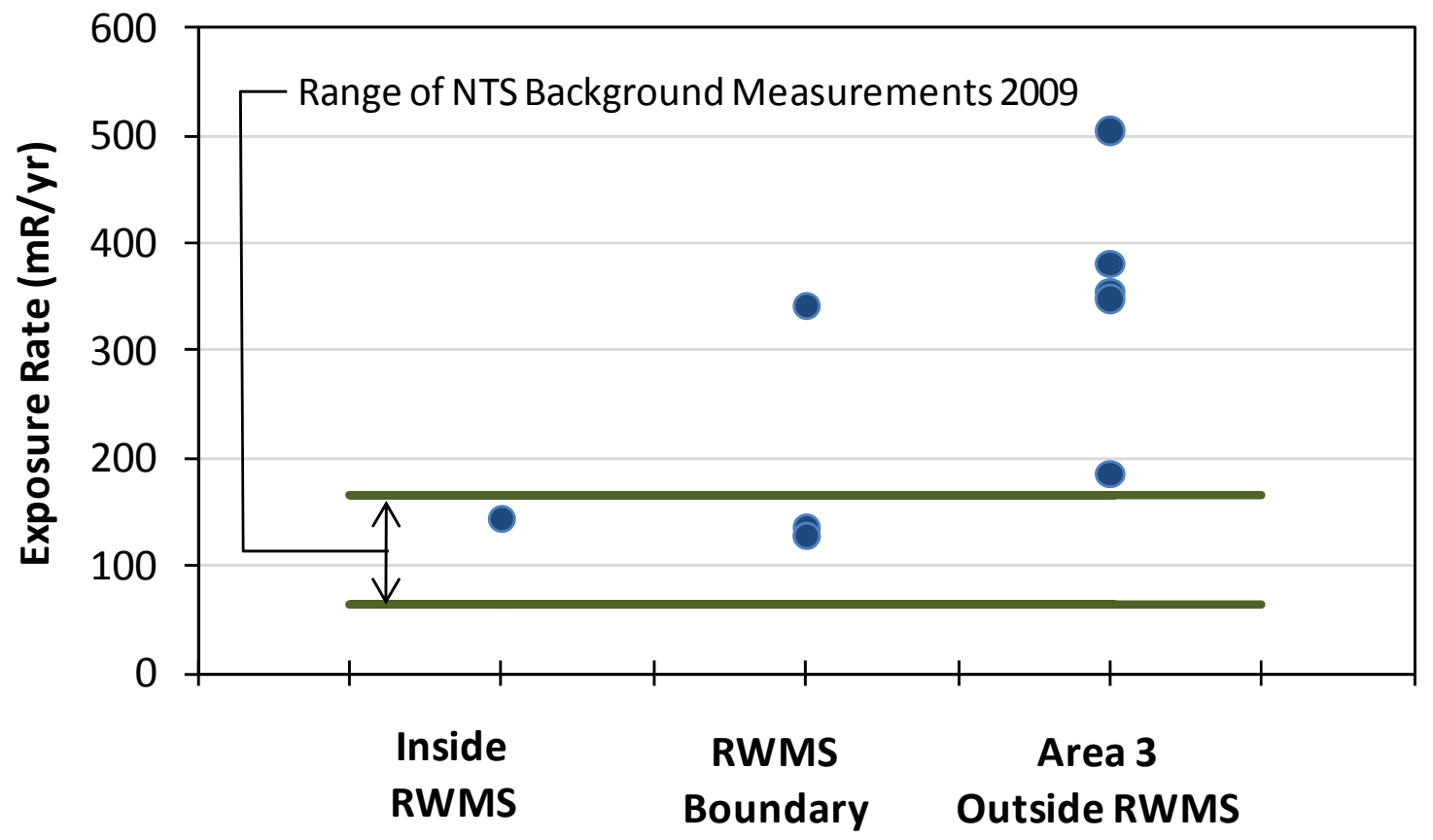

Figure 4-1 Annual Radiation Exposure Rates at the Area 3 RWMS 


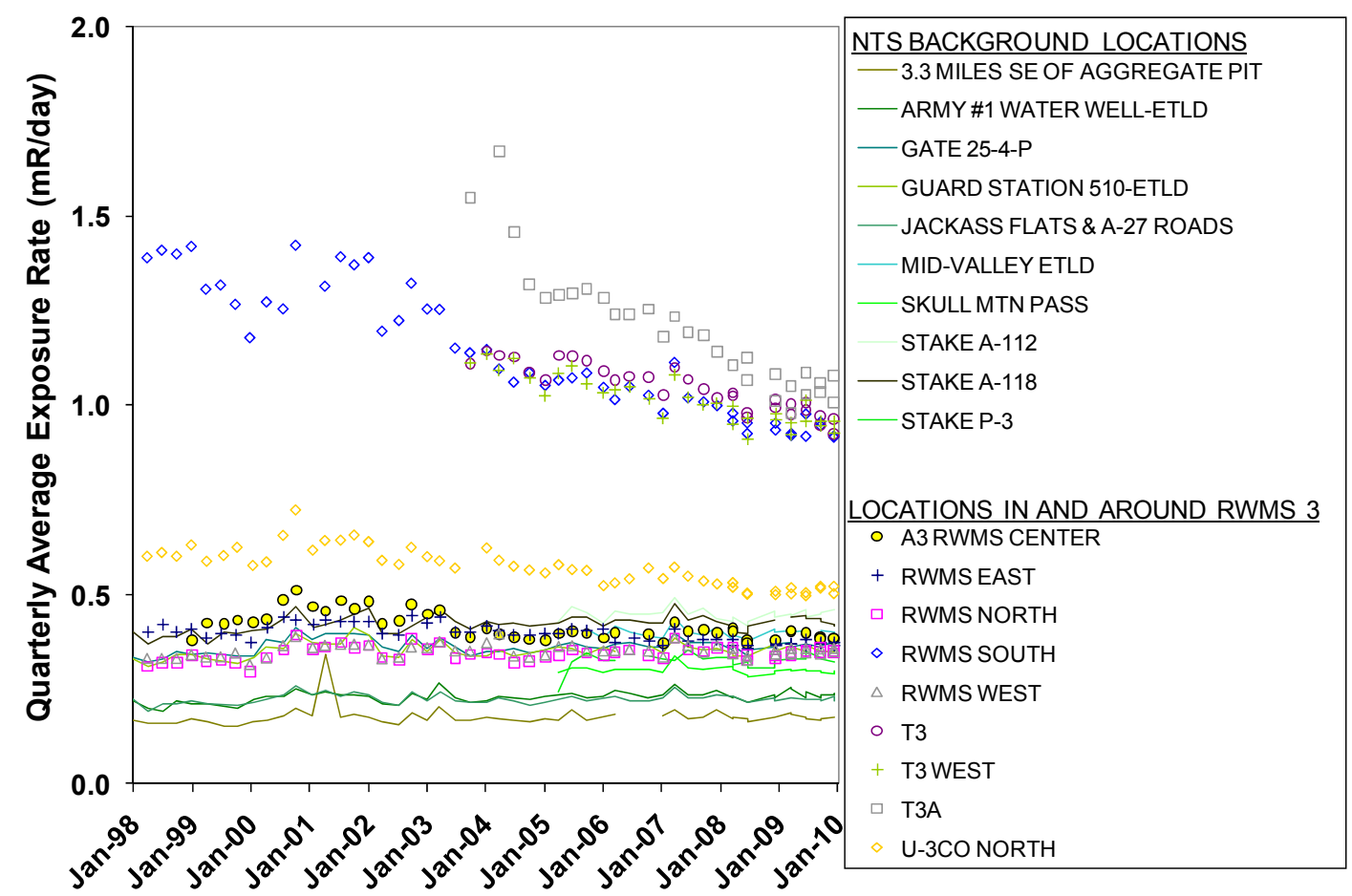

Figure 4-2 Quarterly Average Daily Exposure Rates at the Area 3 RWMS and NTS Background TLD Locations from 1998 to 2009

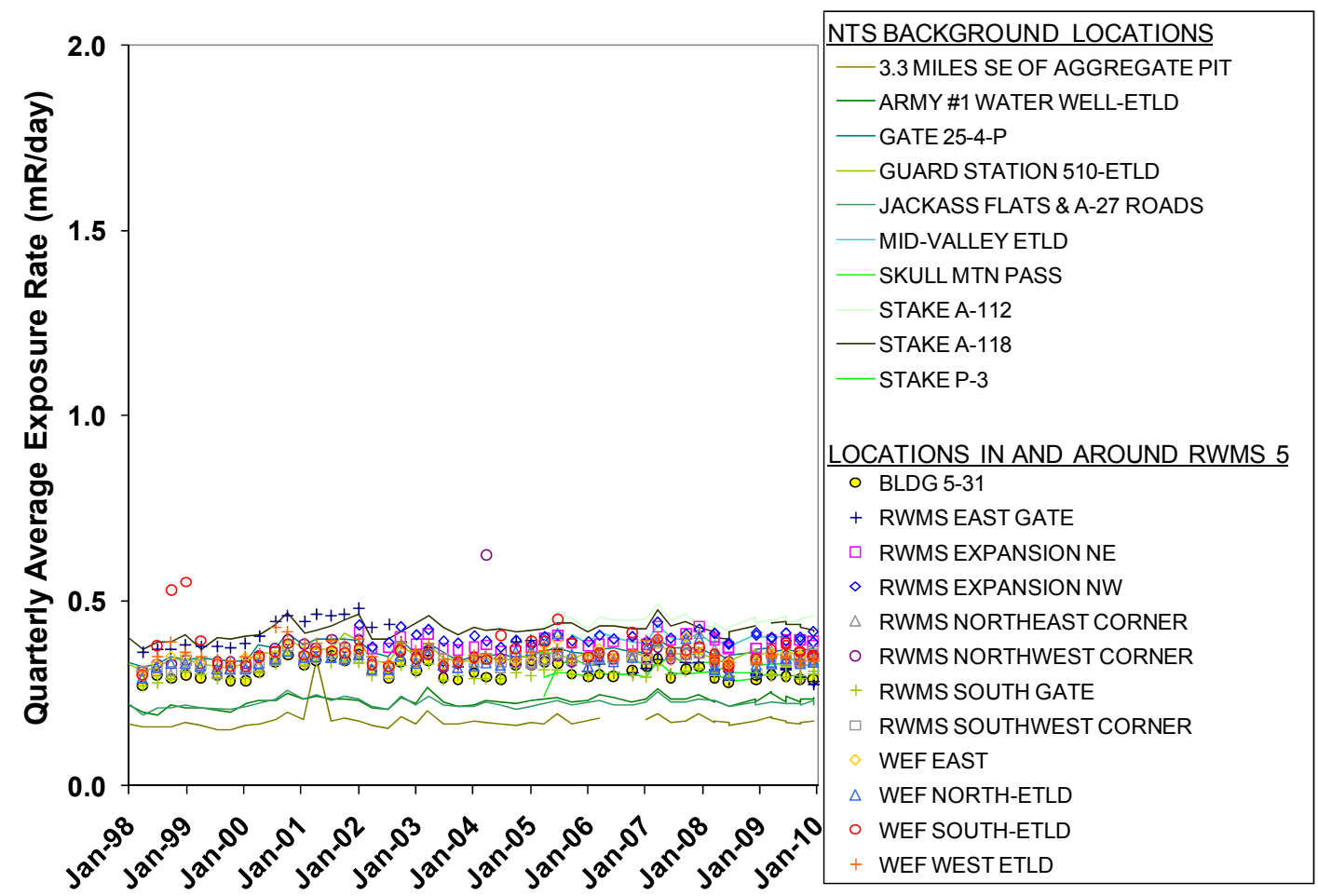

Figure 4-3 Quarterly Average Daily Exposure Rates at the Area 5 RWMS and NTS Background TLD Locations from 1998 to 2009 


\subsection{AIR MONITORING DATA}

\subsubsection{Tritium}

Tritium is a highly mobile isotope of hydrogen that acts as a conservative tracer and is therefore an excellent performance indicator of volatile radionuclide migration from waste cells.

Atmospheric moisture is continuously collected at the Area 3 and Area 5 RWMSs and analyzed for tritium. Approximately 11 cubic meters $\left(\mathrm{m}^{3}\right)$ (388 cubic feet [ $\left.\left.\mathrm{ft}^{3}\right]\right)$ of air are drawn across a desiccant during each two-week sample period to collect atmospheric moisture. The moisture is distilled from the desiccant, and the tritium activity is measured by liquid scintillation.

The two tritium monitoring locations at the Area 3 RWMS are U-3bh N and U-3ah/at S (Figure 3-1). The two Area 5 RWMS monitoring locations are DoD, which is approximately $1.0 \mathrm{~km}(0.6 \mathrm{mi})$ north of the Area $5 \mathrm{RWMS}$, and Sugar Bunker, which is approximately $1.5 \mathrm{~km}$ $(0.9 \mathrm{mi})$ south of the Area $5 \mathrm{RWMS}$ (Figure 3-3). These monitoring locations are in the prevailing downwind directions to provide adequate environmental monitoring for each RWMS.

During 2009, tritium concentrations at the Area 3 and Area 5 RWMSs ranged from -0.32 to 2.01 picocuries per cubic meter $\left(\mathrm{pCi} / \mathrm{m}^{3}\right)$ with all results well below the DOE Derived Concentration Guide (DCG) (DOE O 5400.5) for tritium adjusted to the $25 \mathrm{mrem} / \mathrm{yr}$ exposure specified in DOE O 435.1. The typically higher tritium concentrations during June through September are not as distinct in 2009 (Figure 4-4).

Water evaporating from the soil surface at the Area 5 RWMS was sampled in 2009 to map the large area (diffuse) tritium source. From August 31, 2009, to September 3, 2009, 10 gram silica gel desiccant packets were placed on the soil surface under inverted metal containers (Figure 4-5). The desiccant packets remained in place on the soil surface for 6 to 22 days (median $=8$ days) after which each was sealed in its container with a lid and removed for analysis. A total of 218 desiccant packets were collected for analysis. The amount of water absorbed by each packet was determined gravimetrically. The net water gain per packet ranged from 0.85 to 3.04 grams with a median of 1.32 grams and was not normally distributed (Kolmogorov-Smirnov normality test, $P=<0.001$ ). The net water gain is significantly higher than field blank desiccant packets that remained sealed in containers on the surface (Mann-Whitney Rank Sum Test, $P=0.048$ ). The tritium activity in each packet was determined by liquid scintillation counting. The minimum detectable concentration (MDC) was relatively high, approximately $23,000 \mathrm{pCi} / \mathrm{L}$, due to the small sample volume absorbed by each packet. The tritium activity in 25 percent of the samples exceeded the MDC. Diffuse tritium results are presented in Figure 4-6. This surface was generated with a geographic information system using an inverse distance weighting technique. This technique may bias the surface towards higher activities particularly in areas with sparse sampling. The highest observed tritium activity is centered on P01 extending to the edges of P06 and T02. Localized higher concentrations are also observed on the southern end of the P04, the middle of the P05 covers, and near some GCD boreholes 


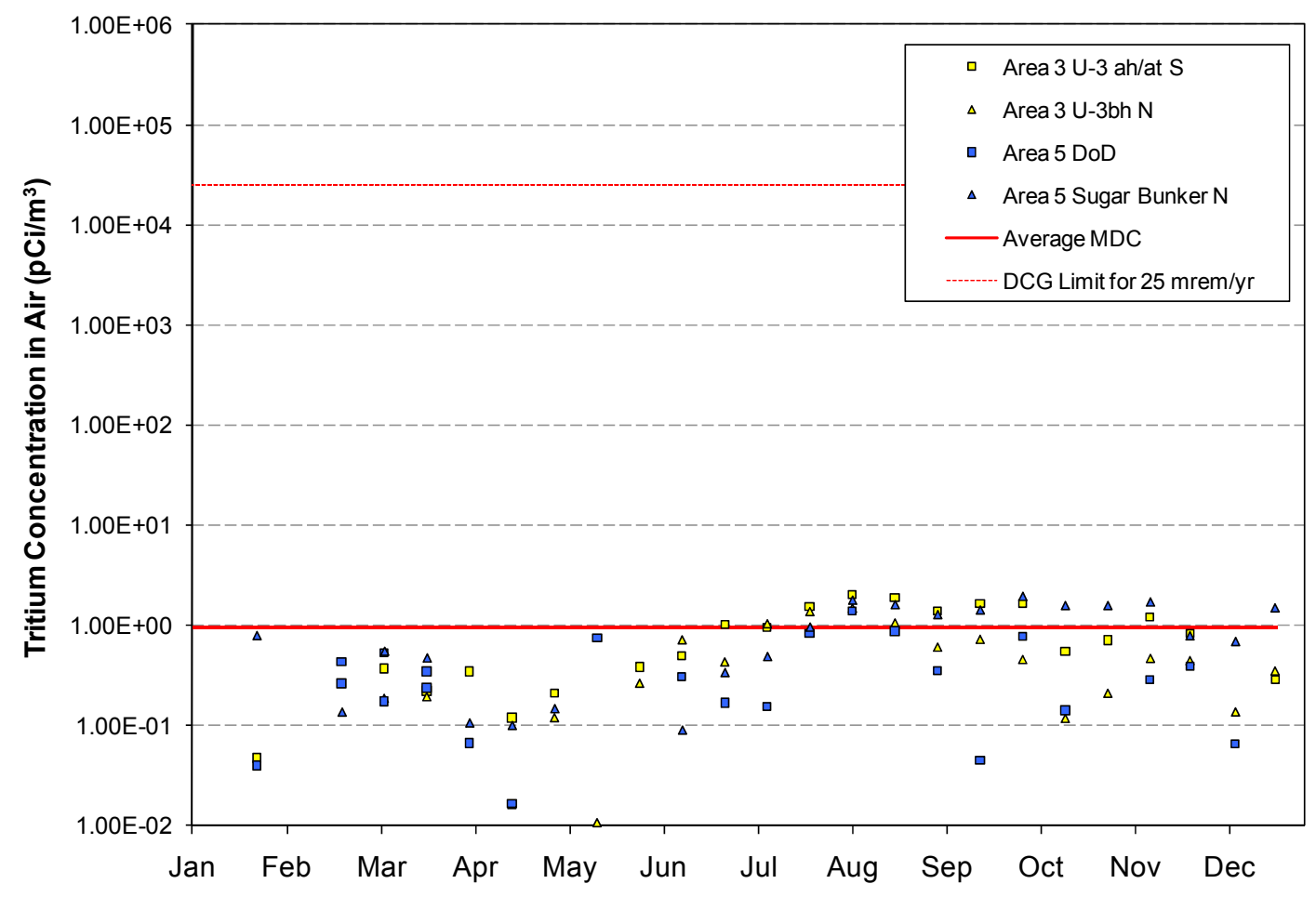

Figure 4-4 Tritium Concentration in Air at the Area 3 and Area 5 RWMSs during 2009
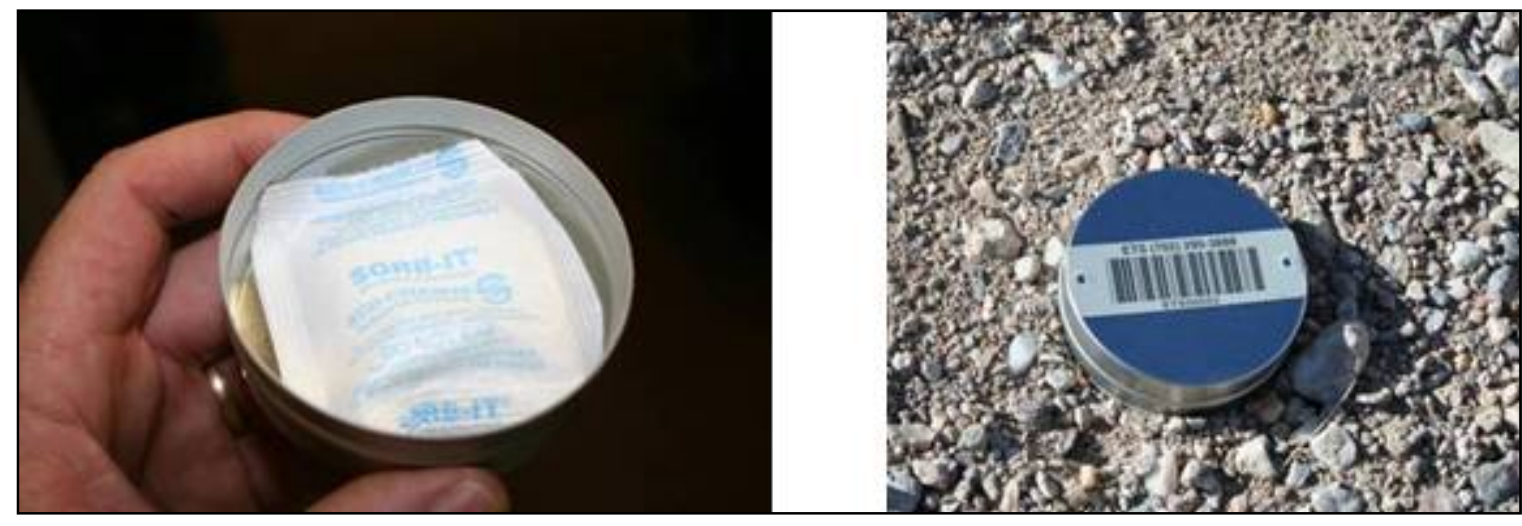

Figure 4-5 Silica Gel Packet and Tin Used to Collect Surface Evaporation 


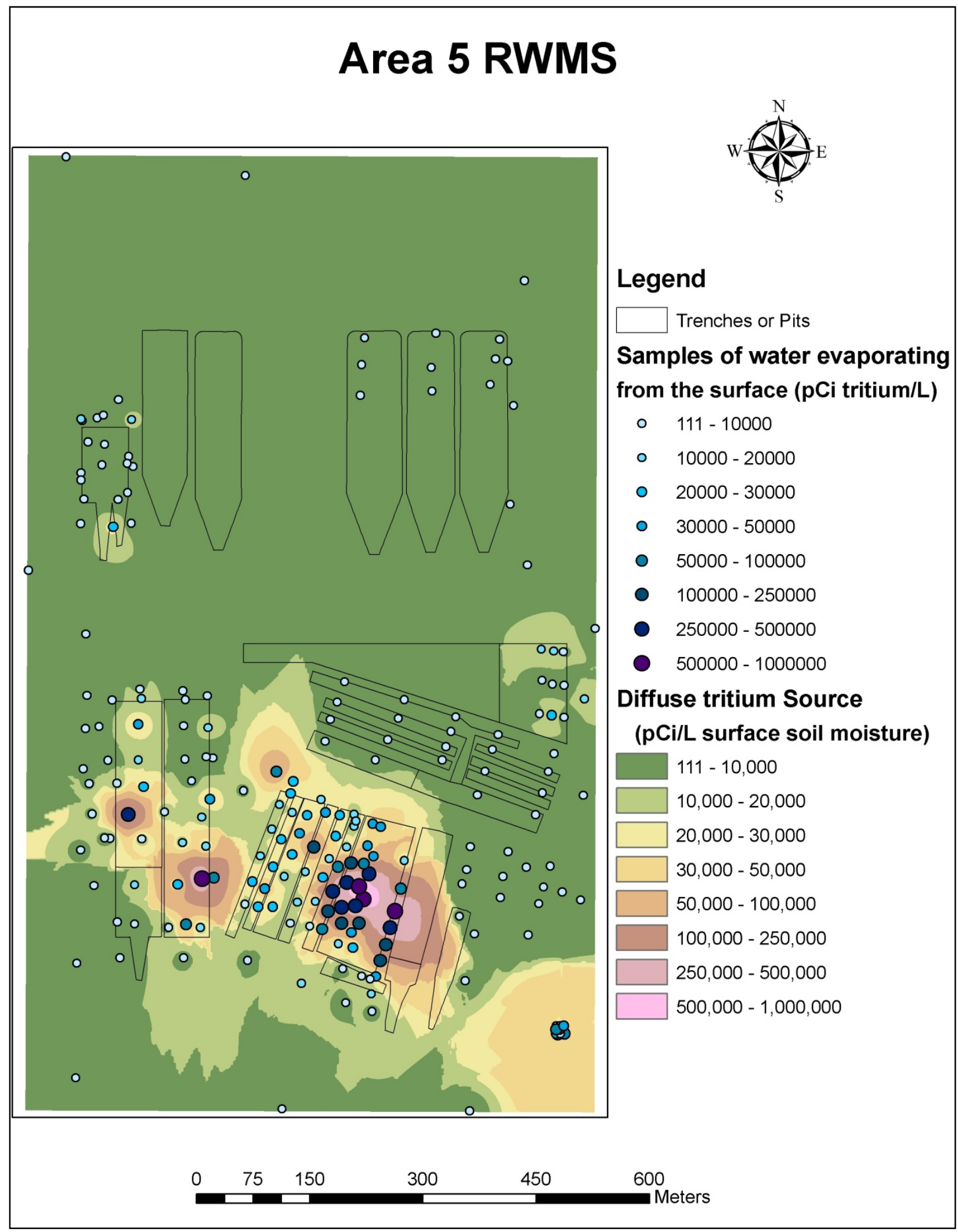

Figure 4-6 Tritium in Surface Soil Moisture at the Area 5 RWMS 


\subsubsection{Particulates}

Air particulate samples are collected weekly on glass-fiber filters near each RWMS and are screened for gross alpha and gross beta radioactivity to provide early detection of any change in environmental concentrations of airborne radioactivity. Monthly composites of the filters from each sampling location are analyzed by gamma spectroscopy for gamma-emitting radioactivity and by radiochemical analyses for americium and plutonium.

The four air particulate monitoring locations at the Area 3 RWMS are U-3bh N, U-3bh S, U-3ah/at N, and U-3ah/at S (Figure 3-1). The two air particulate monitoring locations at the Area 5 RWMS are DoD and Sugar Bunker (Figure 3-3).

All gamma spectroscopy results for man-made radionuclides from 2009 are below their associated sample-specific MDC. The alpha spectroscopy results from 2009 for each location are above the MDCs in 8 to 58 percent of the samples for ${ }^{241} \mathrm{Am}$ (Figure 4-7), above the MDCs in 0 to 17 percent of samples for ${ }^{238} \mathrm{Pu}$ (Figure 4-8), and above the MDCs in 13 to 92 percent of samples for ${ }^{239+240} \mathrm{Pu}$ (Figure 4-9). The americium and plutonium concentrations at the Area 3 RWMS are slightly higher than at the Area 5 RWMS. There is no indication that RWMS operations contributed americium or plutonium activity above normal variability observed at all locations. All measured concentrations of americium and plutonium were below the DCG, adjusted to $25 \mathrm{mrem} / \mathrm{yr}$, for each radionuclide.

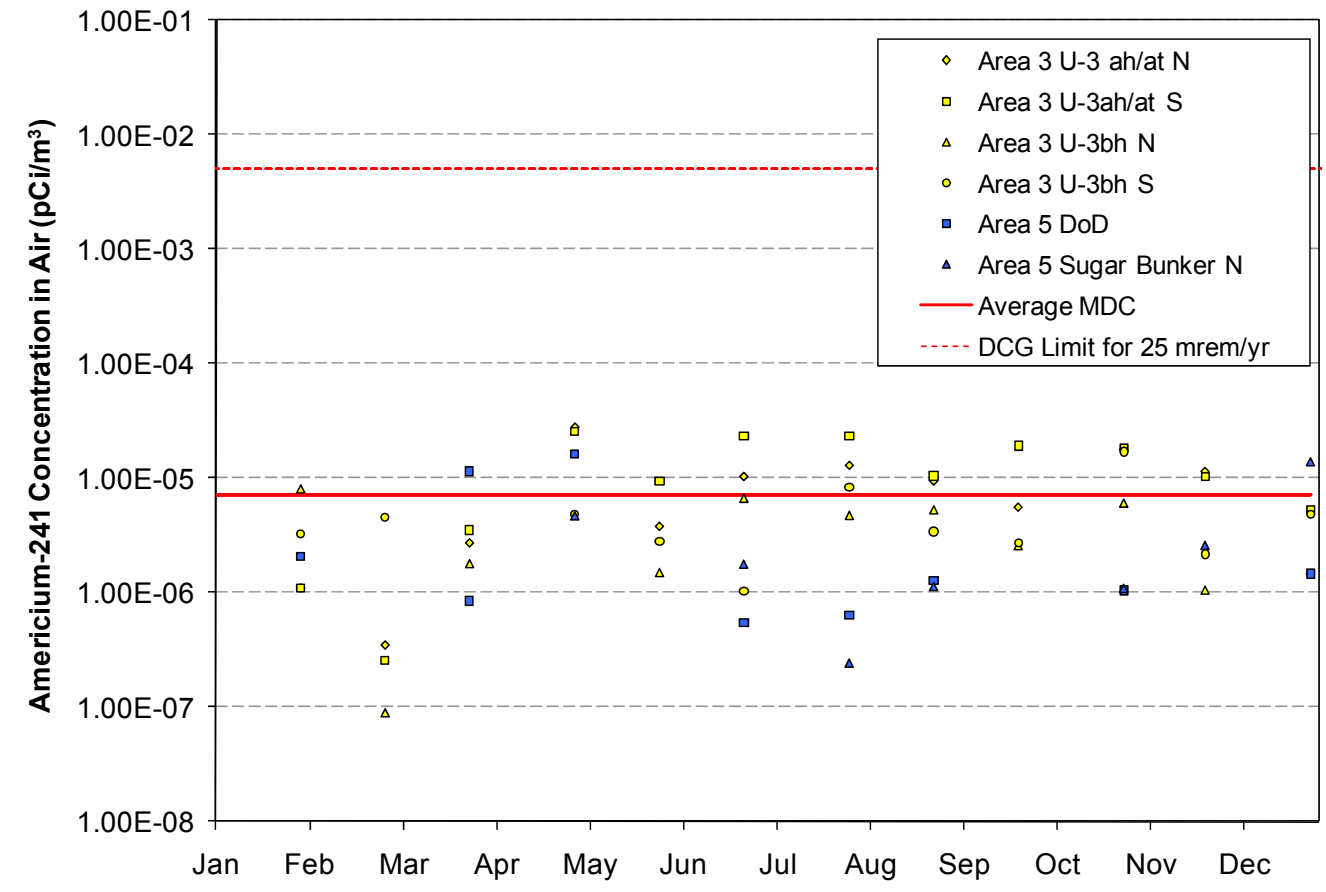

Figure 4-7 Concentration of ${ }^{241} \mathrm{Am}$ in Air at the Area 3 and Area 5 RWMSs during 2009 


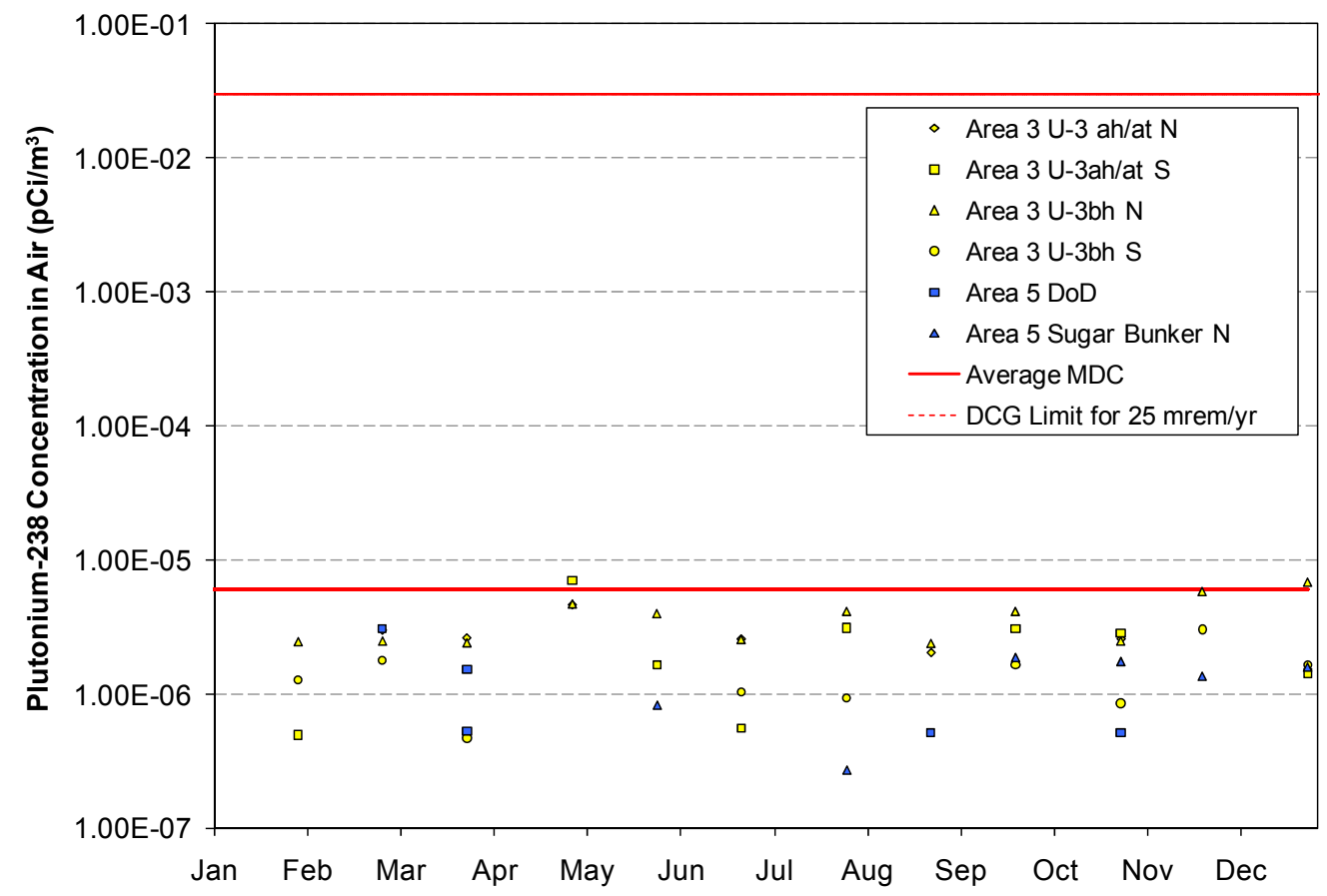

Figure 4-8 Concentration of ${ }^{238} \mathrm{Pu}$ in Air at the Area 3 and Area 5 RWMSs during 2009

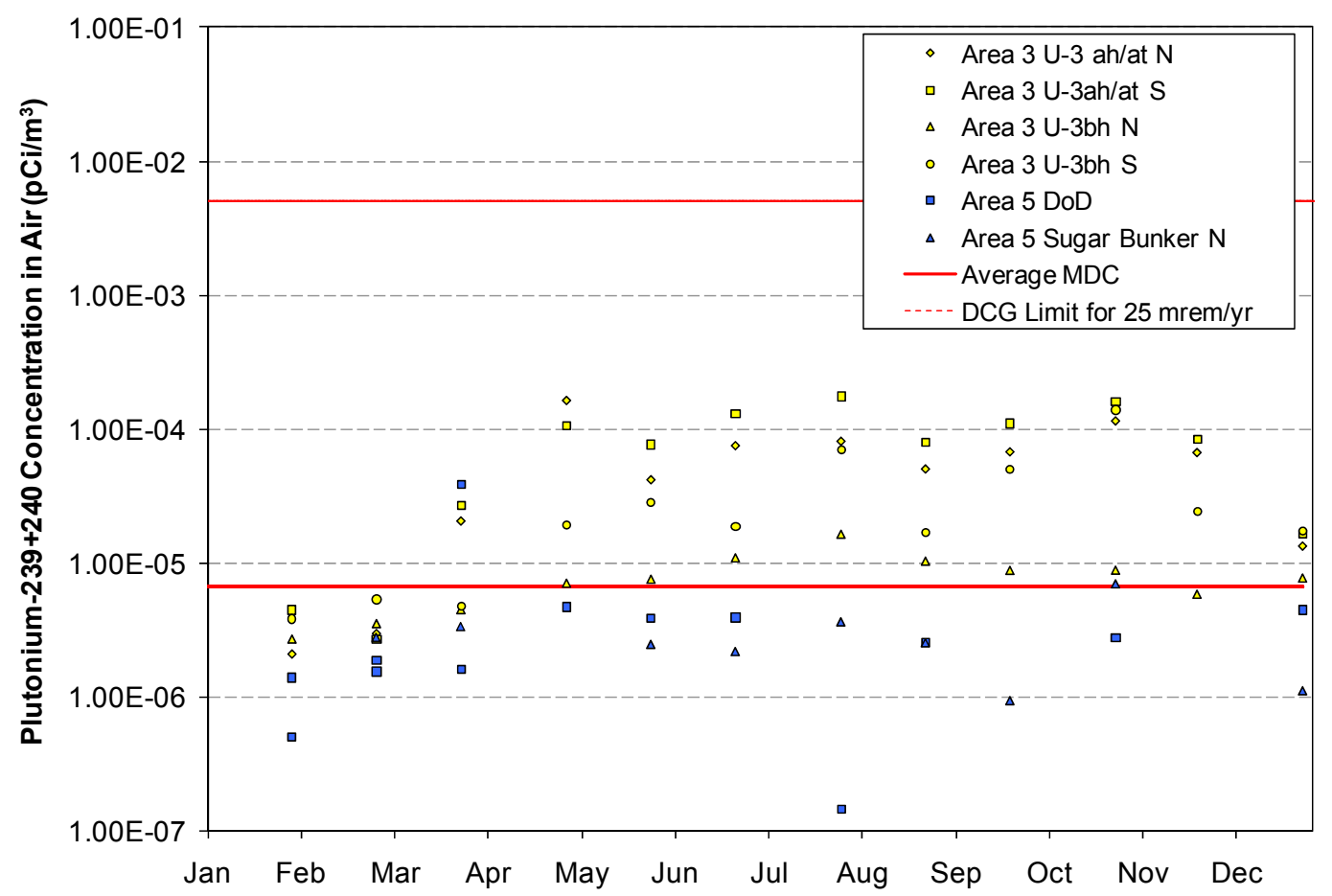

Figure 4-9 Concentration of ${ }^{239+240} \mathrm{Pu}$ in Air at the Area 3 and Area 5 RWMSs during 2009 


\subsubsection{Radon}

The performance objective (DOE M 435.1-1) for radon emissions from DOE radioactive waste facilities is 20 picocuries per square meter per second $\left(\mathrm{pCi} / \mathrm{m}^{2} / \mathrm{s}\right)$. Radon flux measurements were made during 2009 at the Area 3 and Area 5 RWMSs for comparison with the regulatory limit. Radon flux was measured on the U-3ax/bl cover in Area 3 and on the P06 cover in Area 5. These covers were selected because they contain radon and thorium-bearing waste. Radon flux was also measured at an undisturbed site outside both the Area 3 and Area 5 RWMSs. Figure 4-10 shows the measurement locations in Area 3, and Figure 4-11 shows the measurement locations in Area 5. Radon flux was measured on all locations during December 23-30, 2009, except the Area 3 control location was measured from December 23, 2009, to January 19, 2010. Measurements were made using radon flux domes (Rad Elec, Inc.) placed on the ground surface. Electrets inserted in the domes are electrically discharged by ionization of air from radon. The amount of discharge is correlated with radon flux from the ground.

Radon flux results from 2000 through 2009 are summarized in Figure 4-12. The surface radon flux remained relatively low on waste covers. All radon flux results were at least 5 times lower than the regulatory limit and there are no apparent increasing trends.

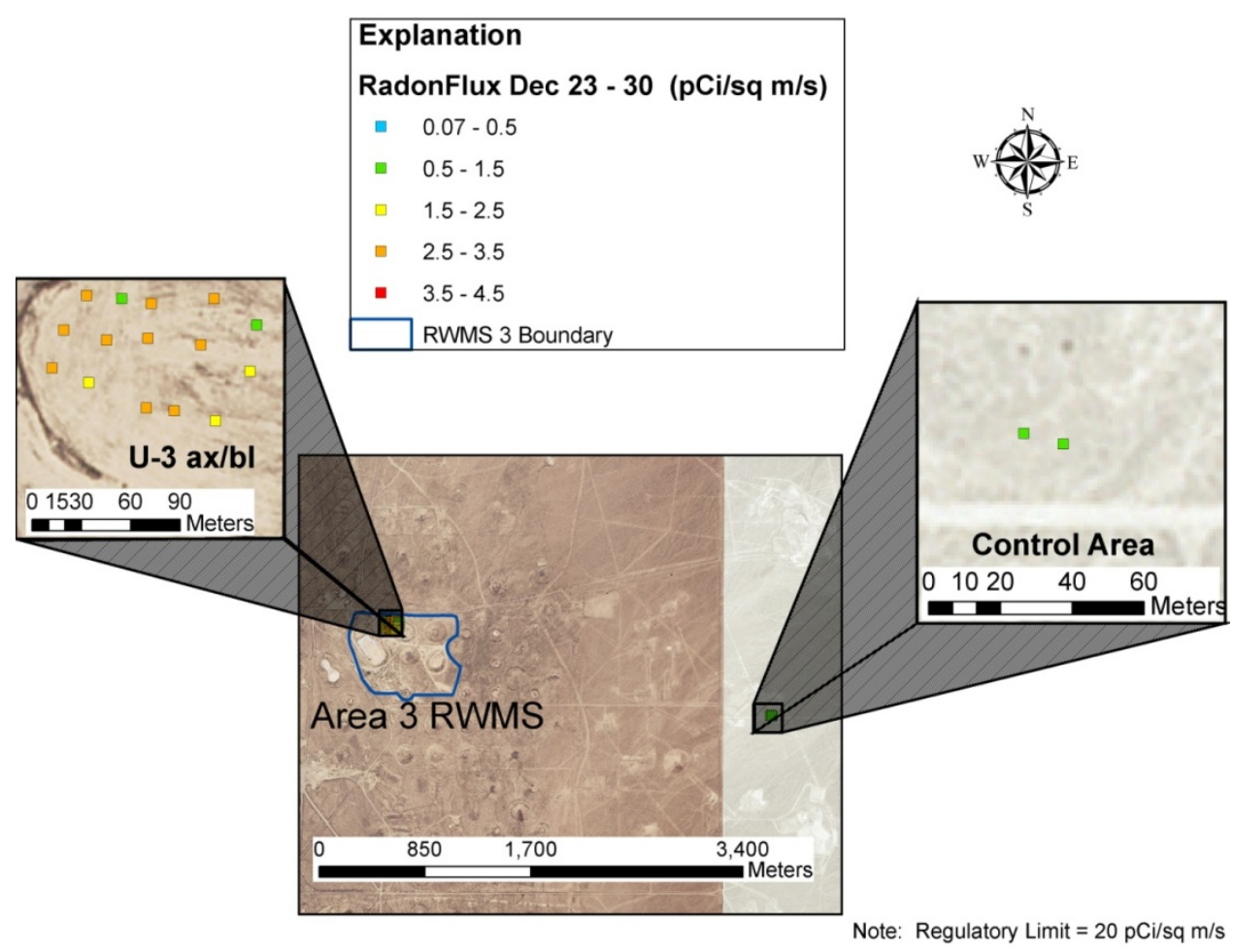

Figure 4-10 Radon Flux Measurement Locations in Area 3 


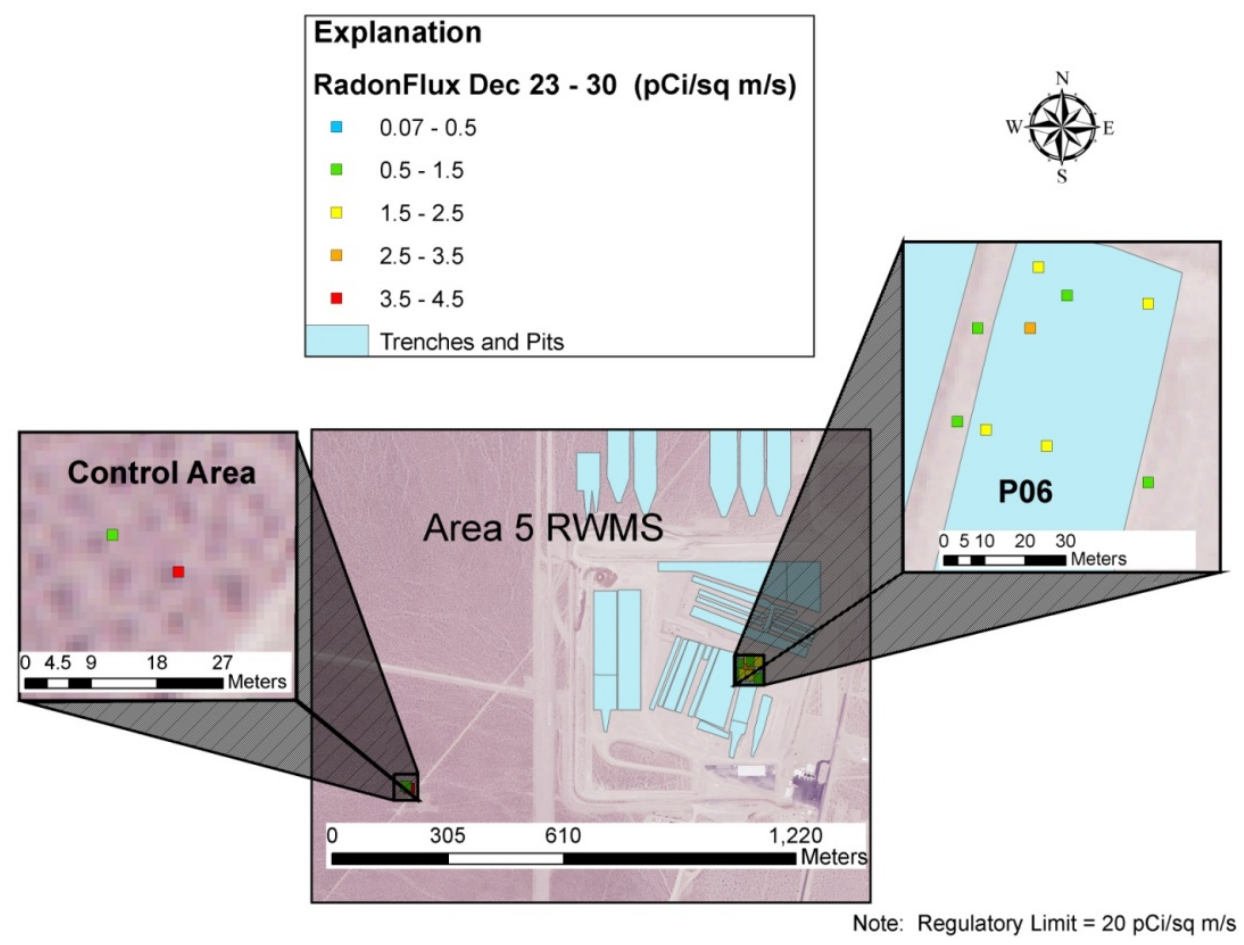

Figure 4-11 Radon Flux Measurement Locations in Area 5

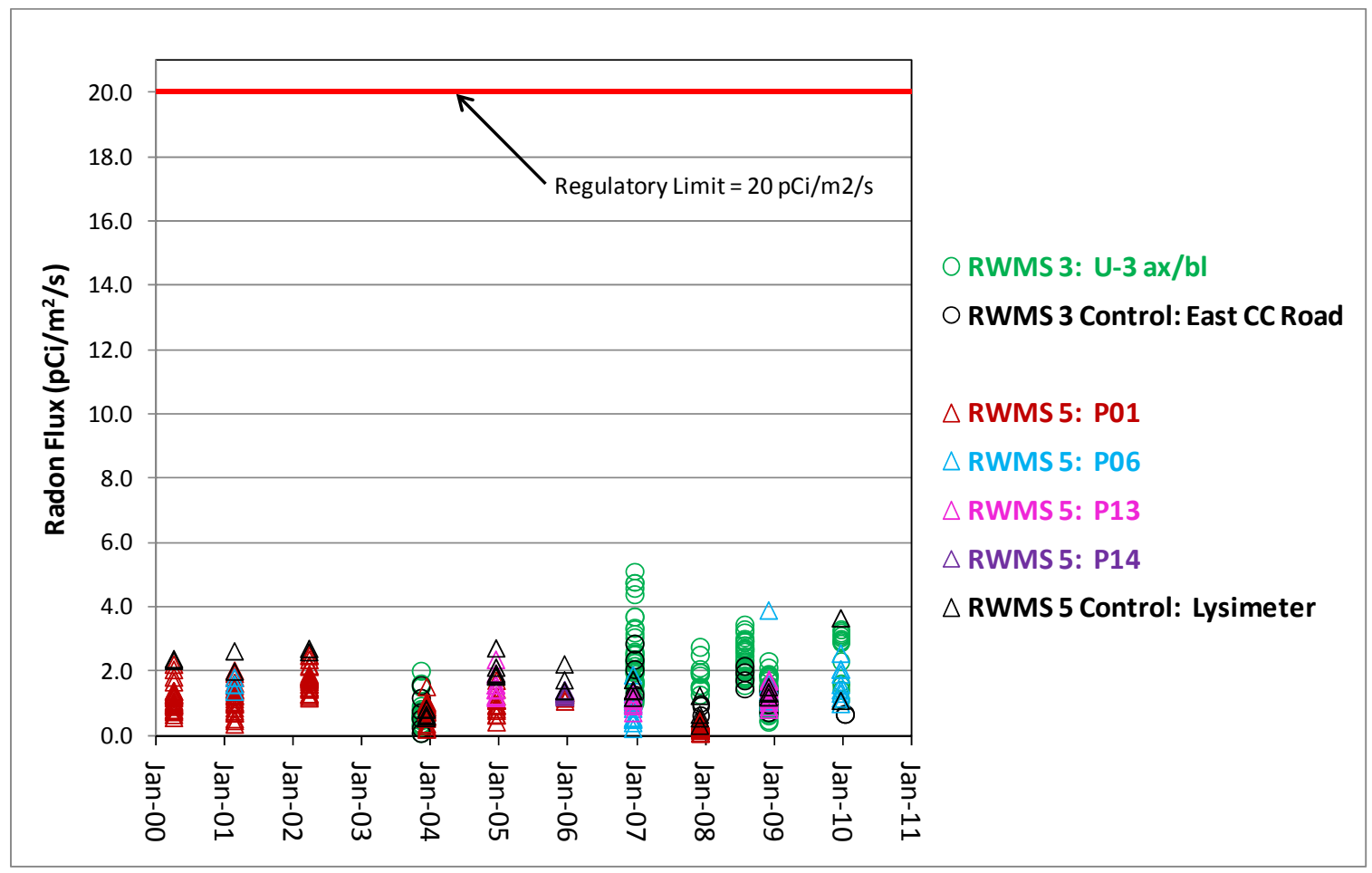

Figure 4-12 Radon Flux Results from 2000 through 2009 


\subsection{GROUNDWATER MONITORING DATA}

Three wells (UE5PW-1, UE5PW-2, and UE5PW-3) were drilled around the perimeter of the Area 5 RWMS in 1993 (see Figure 3-3). These wells are sampled twice a year to monitor the groundwater below the Area 5 RWMS. During 2009, these wells were sampled on March 10 and August 18. Investigation levels (ILs) have been established for five indicators of contamination migration. The measured indicators are SC, $\mathrm{pH}, \mathrm{TOC}, \mathrm{TOX}$, and tritium. Further groundwater analyses are required if any analyte exceeds its IL. Results from 2009 are summarized in Table 1. General water chemistry parameters are also measured.

To date, all analytical data from groundwater sampling events from the wells indicate that the groundwater in the uppermost aquifer is unaffected by activities at the Area 5 RWMS. Detailed information and data on the groundwater monitoring program at the Area 5 RWMS are presented in the Nevada Test Site 2009 Data Report: Groundwater Monitoring Program, Area 5 Radioactive Waste Management Site (NSTec, 2010).

Table 1 Investigation Levels and Results from 2009 Groundwater Monitoring

\begin{tabular}{||ccc||}
\hline $\begin{array}{c}\text { Indicator } \\
\text { Parameter }\end{array}$ & $\begin{array}{c}\text { Investigation } \\
\text { Level }\end{array}$ & Results \\
\hline $\mathrm{pH}$ & $<7.6$ or $>9.2$ & 8.17 to 8.45 \\
$\mathrm{SC}$ & $0.440 \mathrm{mmhos} / \mathrm{cm}$ & 0.363 to $0.386 \mathrm{mmhos} / \mathrm{cm}$ \\
TOX & $1 \mathrm{mg} / \mathrm{L}$ & $<0.5$ to $0.69 \mathrm{mg} / \mathrm{L}$ \\
TOC & $50 \mu \mathrm{gg}$ & $<5.2$ to $<7.7 \mu \mathrm{g} / \mathrm{L}$ \\
Tritium & $2,000 \mathrm{pCi} / \mathrm{L}$ & -6.22 to $13.6 \mathrm{pCi} / \mathrm{L}$ \\
\hline \hline
\end{tabular}

Units are millimhos per centimeter (mmhos/cm), milligrams per liter $(\mathrm{mg} / \mathrm{L})$, micrograms per liter $(\mu \mathrm{g} / \mathrm{L})$, and picocuries per liter $(\mathrm{pCi} / \mathrm{L})$.

Groundwater elevation is measured quarterly using an electronic tape. All groundwater elevation data since the wells were drilled in 1993 are shown in Figure 4-13. The 2009 average depths to groundwater from the top of casing are $235.79 \mathrm{~m}(773.59 \mathrm{ft})$ at UE5PW-1, $256.42 \mathrm{~m}(841.26 \mathrm{ft})$ at UE5PW-2, and $271.53 \mathrm{~m}(890.83 \mathrm{ft})$ at UE5PW-3. The average groundwater elevations are $733.58 \mathrm{~m}(2406.77 \mathrm{ft})$ AMSL at UE5PW-1, $733.71 \mathrm{~m}(2407.17 \mathrm{ft})$ AMSL at UE5PW-2, and 733.70 (2407.14 ft) AMSL at UE5PW-3. These data indicate that the water table beneath the Area 5 RWMS is flat, with little or no groundwater flow. Estimated groundwater flow velocity is less than $0.09 \mathrm{~m} /$ year $(0.30 \mathrm{ft} / \mathrm{year})$ to the south. 


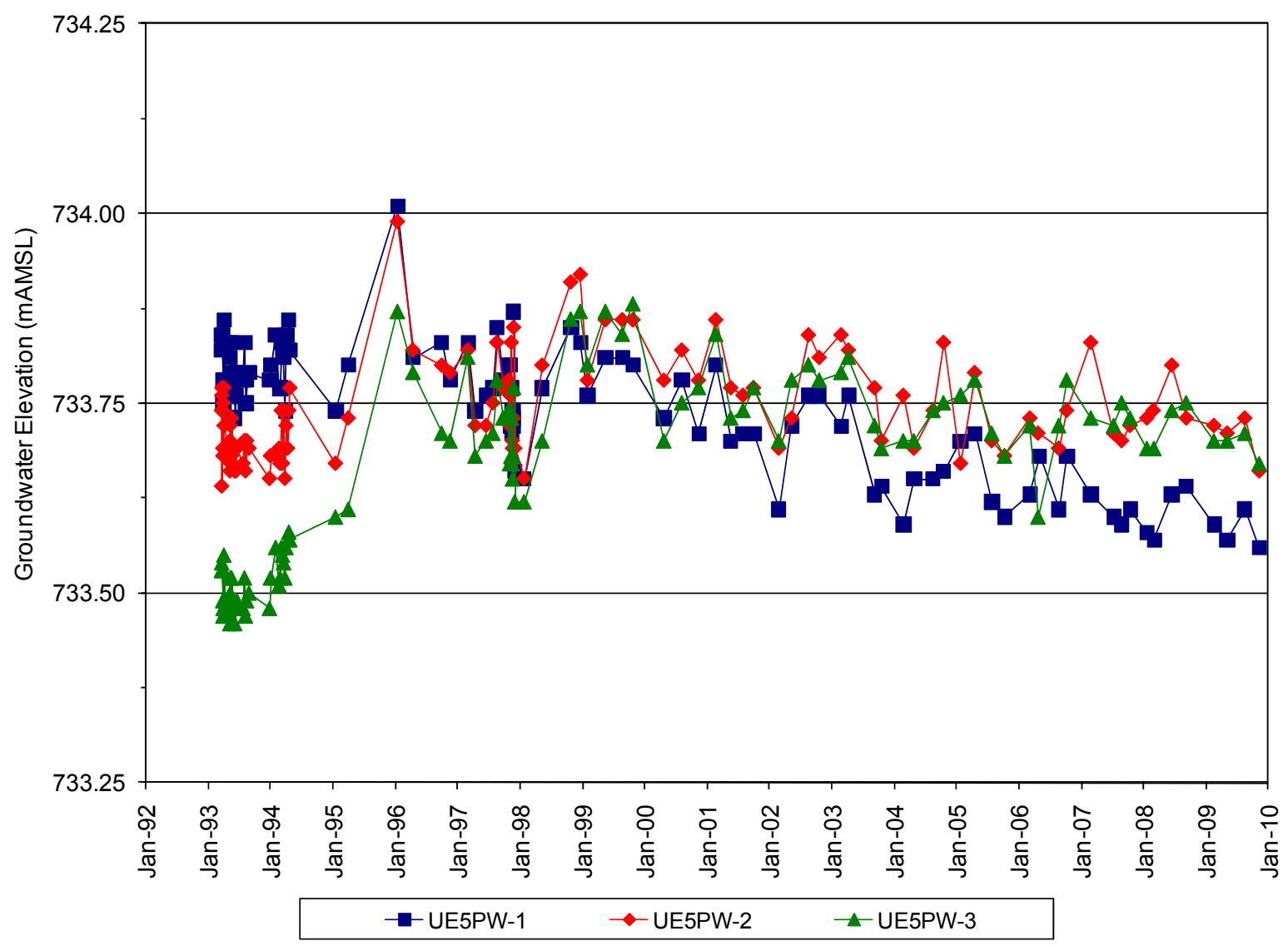

Figure 4-13 Groundwater Elevation at the Three Area 5 RWMS Pilot Wells 


\subsection{METEOROLOGY MONITORING DATA}

Meteorology monitoring data collected in 2009 include precipitation, air temperature, humidity, wind speed and direction, barometric pressure, and incoming solar radiation. These are basic meteorological parameters required to quantify the exchange of water and heat between the soil and the atmosphere. These data were collected from two meteorology stations, one located approximately $30 \mathrm{~m}(100 \mathrm{ft})$ northwest of the Area $3 \mathrm{RWMS}$, and one near the Area $5 \mathrm{RWMS}$ about $100 \mathrm{~m}$ (328 ft) north from Well UE5PW-1 (see Figure 3-1 and Figure 3-2).

\subsubsection{Air Temperature}

Air temperatures at the Area 3 RWMS are slightly cooler than air temperatures at the Area 5 RWMS. The 2009 average recorded temperatures at $3 \mathrm{~m}(10 \mathrm{ft})$ are $14.1^{\circ} \mathrm{C}\left(57.4^{\circ} \mathrm{F}\right)$ at the Area 3 RWMS and $16.3^{\circ} \mathrm{C}\left(61.3^{\circ} \mathrm{F}\right)$ at the Area 5 RWMS. The 2009 maximum and minimum temperatures at $3 \mathrm{~m}(10 \mathrm{ft})$ are $39.5^{\circ} \mathrm{C}\left(103.1^{\circ} \mathrm{F}\right)$ on July 18,2009 , and $-18.0^{\circ} \mathrm{C}\left(-0.4^{\circ} \mathrm{F}\right)$ on December 9,2009 , at the Area 3 RWMS and $42.5^{\circ} \mathrm{C}\left(108.5^{\circ} \mathrm{F}\right)$ on July 18,2009 , and $-12.9^{\circ} \mathrm{C}$ $\left(8.8^{\circ} \mathrm{F}\right)$ on December 9, 2009, at the Area 5 RWMS (Figure 4-14)

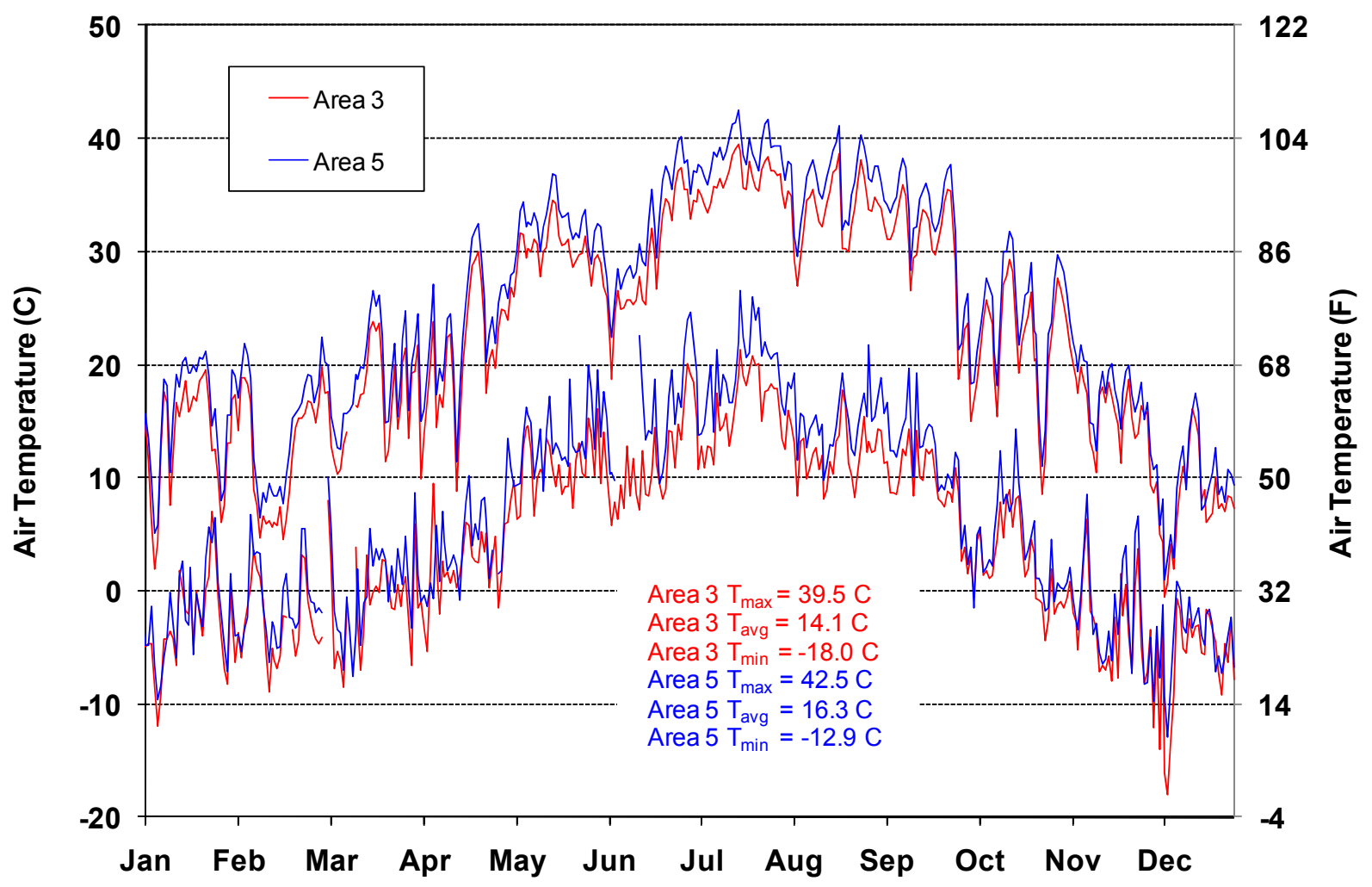

Figure 4-14 Daily Maximum and Minimum Temperature at the Area 3 and Area 5 RWMSs 


\subsubsection{Relative Humidity}

Measured relative humidity at the Area 3 RWMS and the Area 5 RWMS is similar. The daily average relative humidity during 2009 at these two sites is approximately 30 percent (Figure 4-15). Measured relative humidity ranged from 4 to 100 percent.

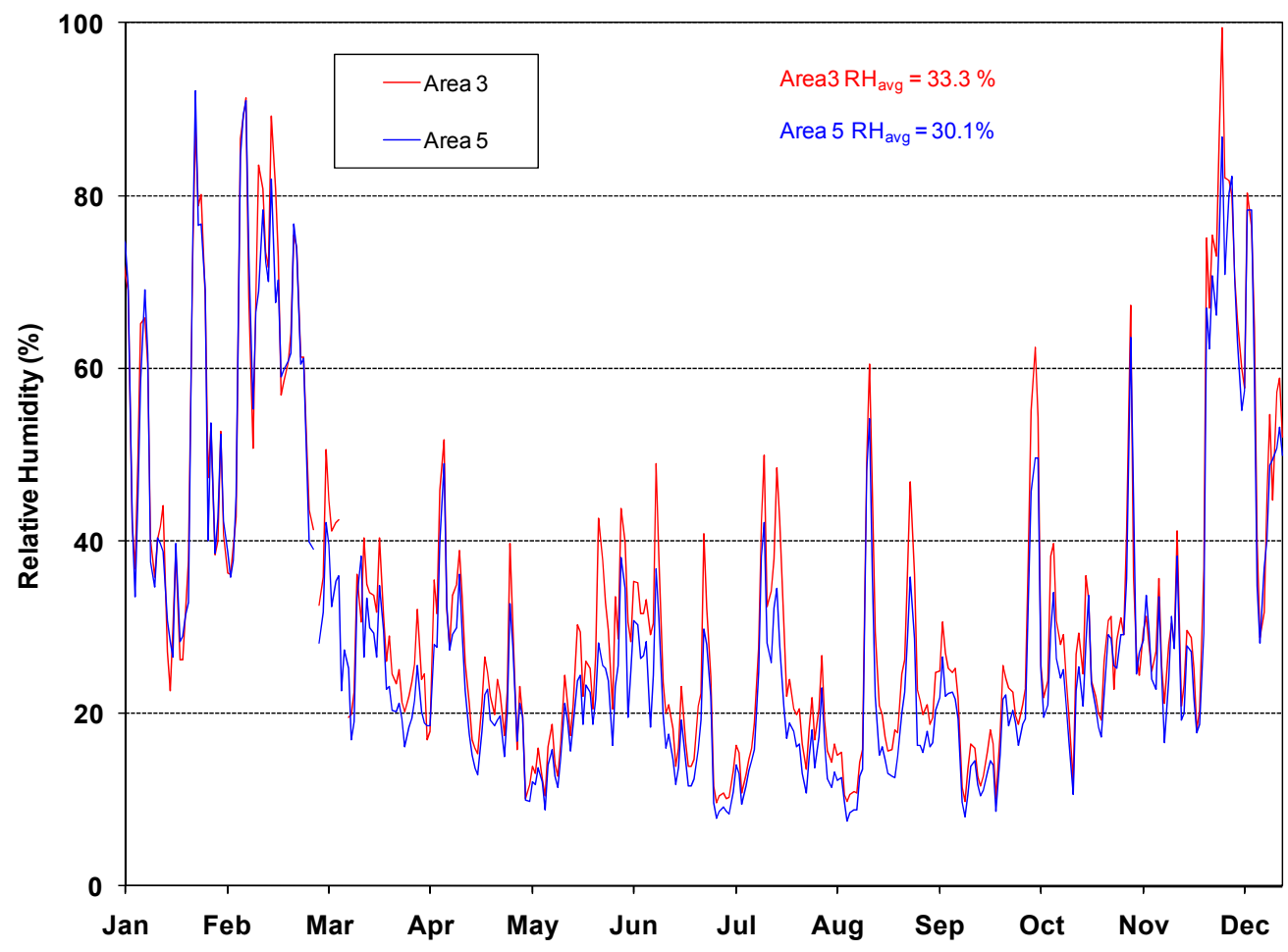

Figure 4-15 Daily Average Relative Humidity at the Area 3 and Area 5 RWMSs 


\subsubsection{Barometric Pressure}

Average daily barometric pressure measured at the Area 3 RWMS and the Area 5 RWMS show very similar patterns (Figure 4-16). The average barometric pressure at the Area 3 RWMS is 87.8 kilopascals $(\mathrm{kPa})$ (12.73 pounds per square inch [PSI]), and the average barometric pressure at the Area $5 \mathrm{RWMS}$ is $90.4 \mathrm{kPa}(13.11 \mathrm{PSI})$. The difference in barometric pressure readings between the two locations is caused by the $261 \mathrm{~m}$ (856 ft) difference in elevation.

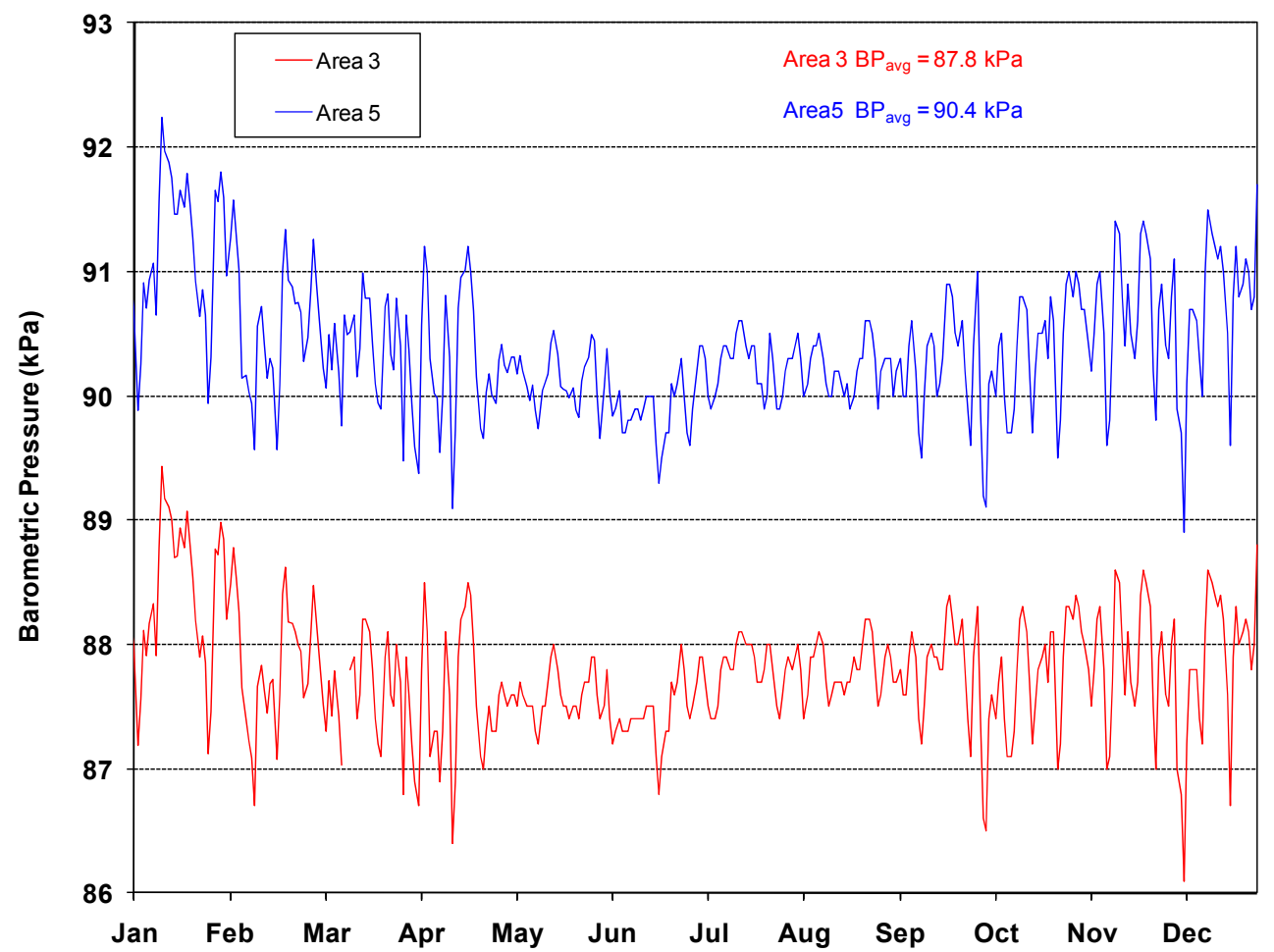

Figure 4-16 Average Barometric Pressure at the Area 3 and Area 5 RWMSs

\subsubsection{Wind Speed and Wind Direction}

The average wind speed is slightly higher at the Area 3 RWMS than at the Area 5 RWMS. During 2009, the average wind speed at the Area 3 RWMS was $3.2 \mathrm{~m} / \mathrm{s}(6.2 \mathrm{mph})$, and the maximum gust was $20.4 \mathrm{~m} / \mathrm{s}(45.6 \mathrm{mph})$ on April 14. During 2009, the average wind speed at the Area 5 RWMS was $3.0 \mathrm{~m} / \mathrm{s}(6.7 \mathrm{mph})$, and the maximum gust was $20.9 \mathrm{~m} / \mathrm{s}(46.6 \mathrm{mph})$ on October 28. Daily maximum and average wind speeds are in Figure 4-17 and Figure 4-18.

Wind rose diagrams illustrate wind direction and wind speed distribution in each direction using hourly wind data measured at a height of $3 \mathrm{~m}$ AGL. Generally, more wind comes from the north and higher wind speeds come from the south. Wind roses from the Area 3 and Area 5 RWMSs are presented in Figure 4-19 and Figure 4-20, respectively. The one-year wind roses presented here are very similar to the multiple-year wind roses. 


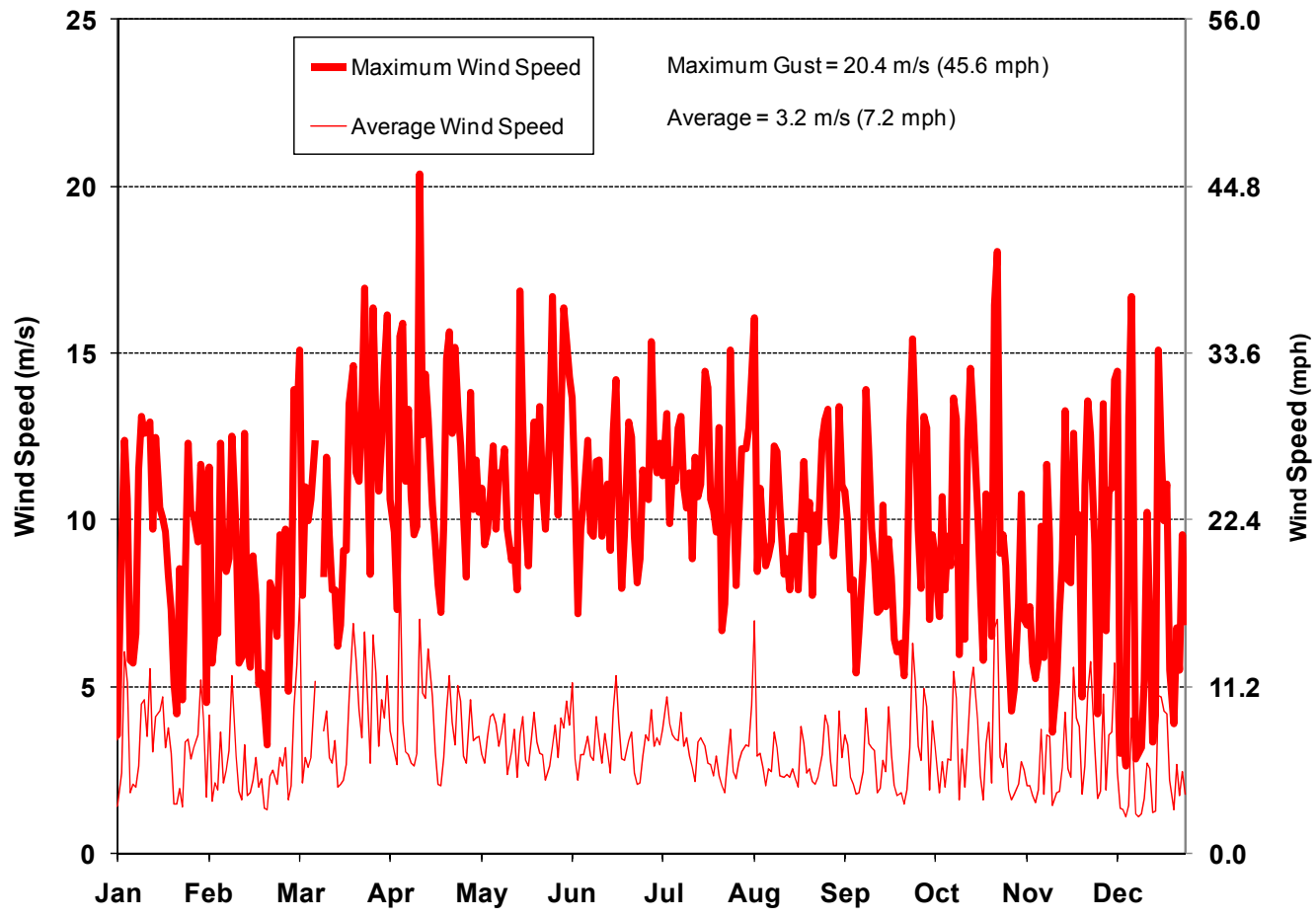

Figure 4-17 Daily $3 \mathrm{~m}$ Wind Speed at the Area 3 RWMS

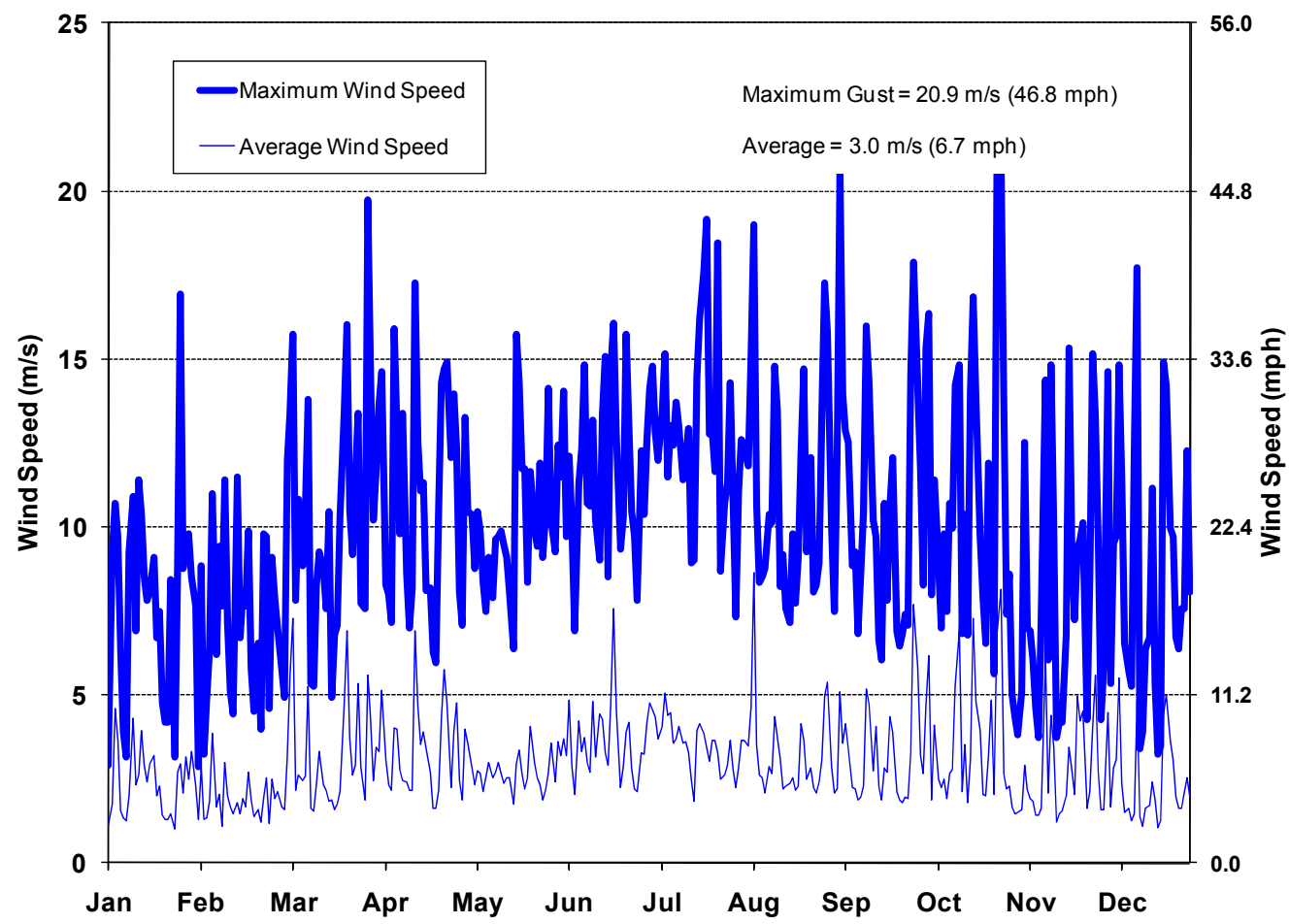

Figure 4-18 Daily $3 \mathrm{~m}$ Wind Speed at the Area 5 RWMS 


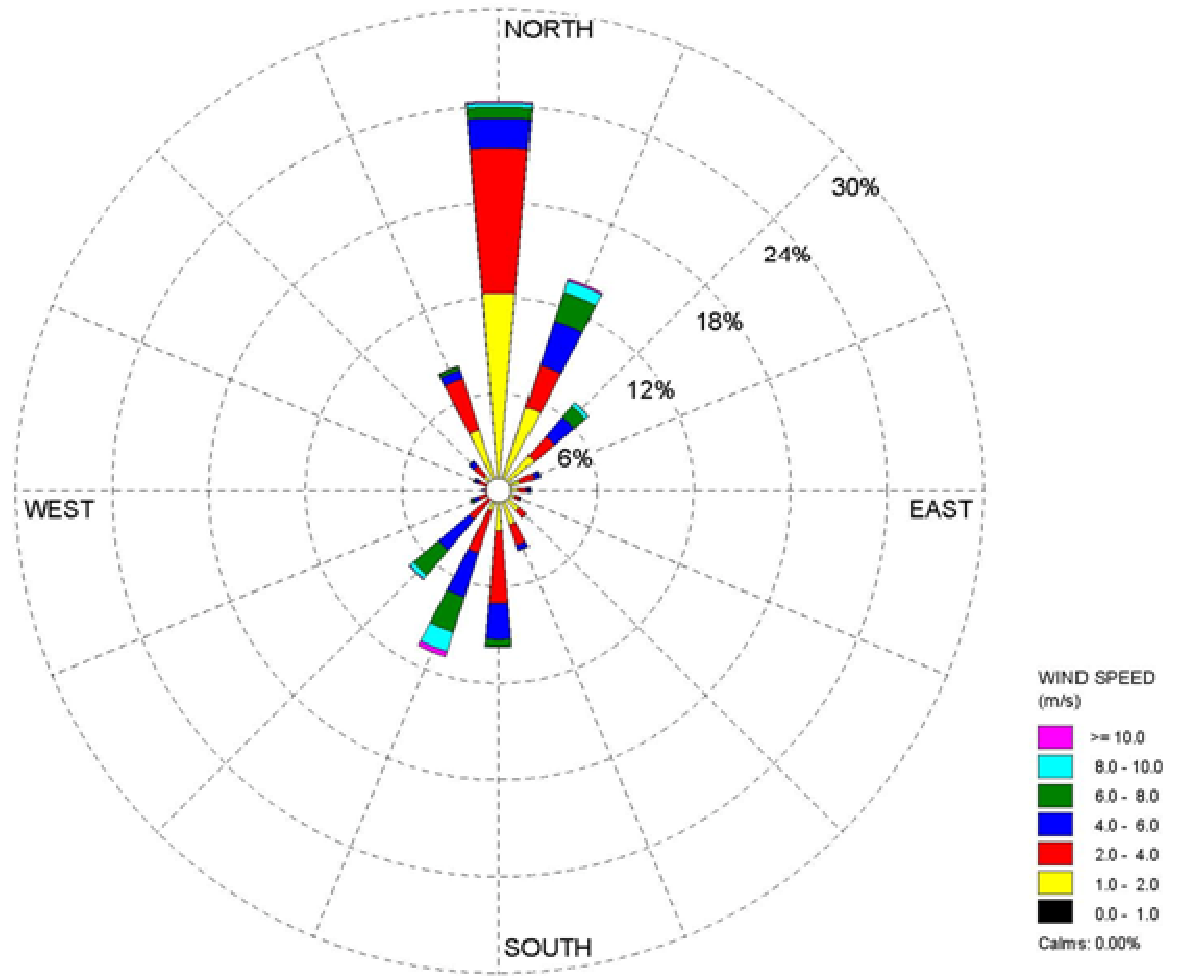

Figure 4-19 Wind Rose Diagram for the Area 3 RWMS

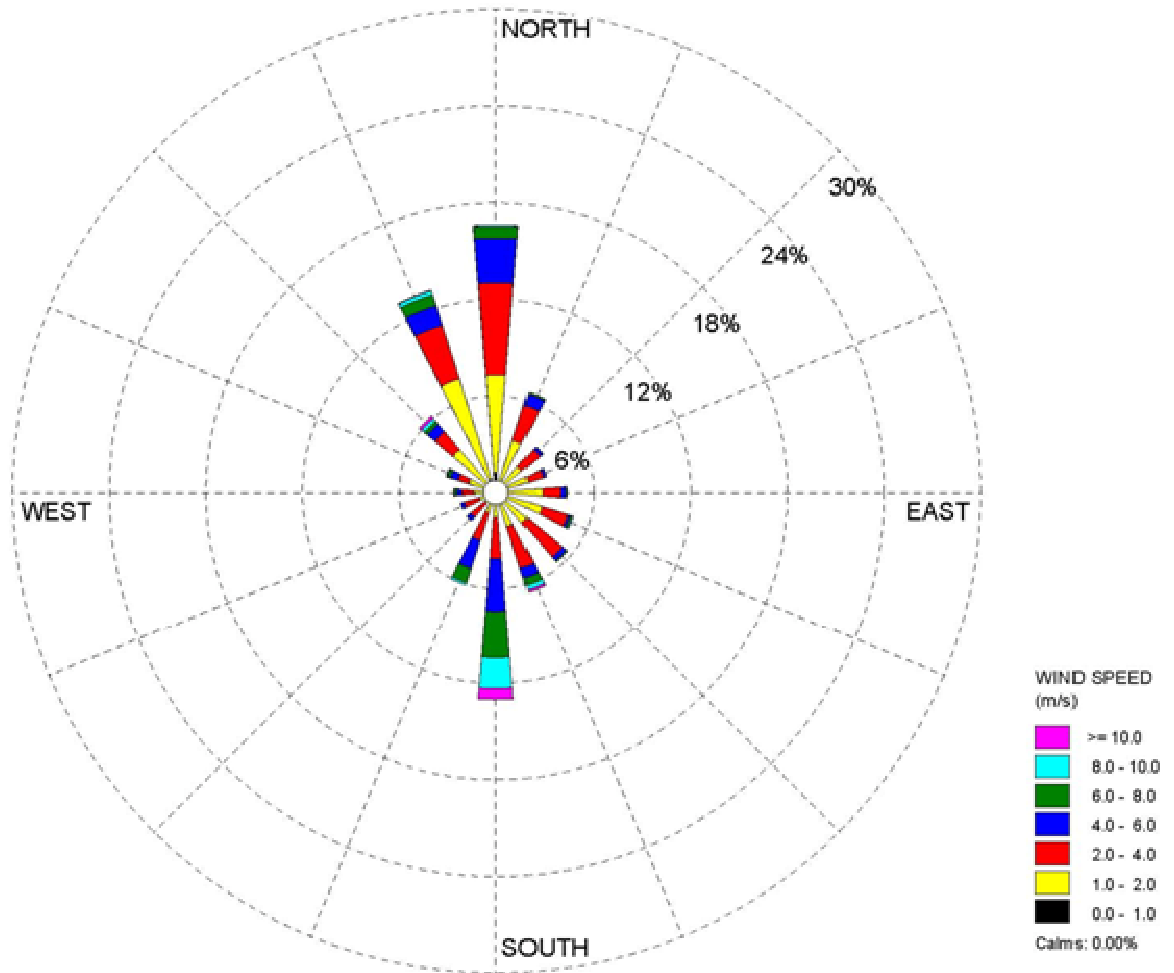

Figure 4-20 Wind Rose Diagram for the Area 5 RWMS 


\subsubsection{Precipitation}

Rainfall at the Area 3 RWMS in 2009 was 43 percent below average, totaling $87.6 \mathrm{~mm}$ (3.45 in.). This is the second driest year since measurements began at the Area 3 RWMS in 1996. The average annual precipitation measured at the Area 3 RWMS for 1996 to 2009 is $152.4 \mathrm{~mm}$ (6.00 in.). The maximum daily rainfall at the Area 3 RWMS during 2009 was $15.8 \mathrm{~mm}$ (0.62 in.) on December 12, 2009. Precipitation was measured on 41 days during 2009 at the Area 3 RWMS (Figure 4-21).

Rainfall at the Area 5 RWMS in 2008 was 48 percent below average, totaling $62.7 \mathrm{~mm}$ (2.47 in.). This is the second driest year since measurements began at the Area 5 RWMS in 1995. The average annual precipitation measured at the Area 5 RWMS for 1995 to 2009 is $122.5 \mathrm{~mm}$ (4.82 in.). The maximum daily rainfall at the Area 5 RWMS during 2009 was $12.1 \mathrm{~mm}$ (0.48 in.) on February 16, 2009. Precipitation was measured on 33 days during 2009 at the Area 5 RWMS (Figure 4-22).

Historical precipitation data recorded at BJY (located about $3 \mathrm{~km}$ [2 mi] northwest of the Area 3 RWMS) and at the Area 3 RWMS are in Figure 4-23. The BJY station is a Meteorological Data Acquisition (MEDA) station operated by ARL/SORD. The 49-year average annual precipitation at BJY from 1961 to 2009 is $161.6 \mathrm{~mm}$ (6.36 in.). Historical precipitation data recorded at the Well 5B station (located about $5.5 \mathrm{~km}$ [3.4 mi] south of the Area 5 RWMS) and at the Area 5 RWMS are provided in Figure 4-24. The Well 5B station is also an ARL/SORD MEDA station. The 47-year average annual precipitation at Well 5B from 1963 to 2009 is $122.2 \mathrm{~mm}$ (4.81 in.).

\subsubsection{Reference Evapotranspiration}

The calculated $2009 \mathrm{ET}_{\text {ref }}$ at the Area 3 RWMS is 1,521 mm (59.9 in.) and at the Area 5 RWMS is $1,545 \mathrm{~mm}$ (60.8 in.). $\mathrm{ET}_{\text {ref }}$ is the rate that readily available soil water is vaporized from a uniform surface of dense, actively growing vegetation. Crop coefficients are used to convert $\mathrm{ET}_{\text {ref }}$ to potential evapotranspiration rates (Allen et al., 2005). $\mathrm{ET}_{\text {ref }}$ is calculated using a modified version of the radiation-based equation of Doorenbos and Pruitt (1977). The equation calculates $\mathrm{ET}_{\text {ref }}$ from hourly measurements of solar radiation, air temperature, relative humidity, wind speed, and barometric pressure. This method provides results similar to the Penman Equation that was previously used for the data reports through 2001 (Campbell, 1977). The Doorenbos and Pruitt equation reduces data input requirements because no net radiation data are used. The ratio of $\mathrm{ET}_{\text {ref }}$ to precipitation in 2009 at the Area $3 \mathrm{RWMS}$ is 17.4 , and the ratio $E T_{\text {ref }}$ to precipitation in 2008 at the Area 5 RWMS is 24.6. The very high ratio of $\mathrm{ET}_{\text {ref }}$ to precipitation during 2009 is caused by the very low precipitation. 


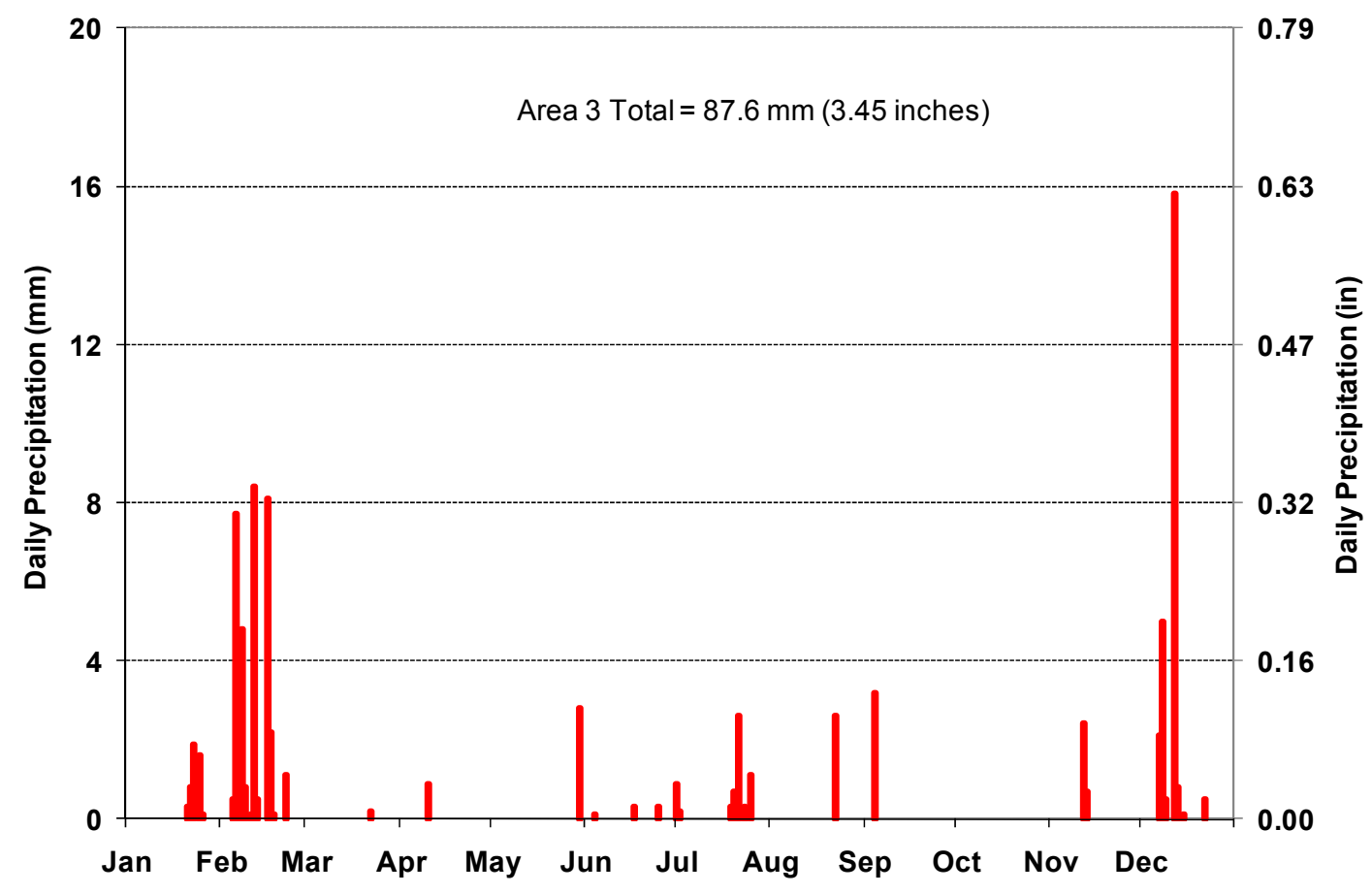

Figure 4-21 Daily Precipitation at the Area 3 RWMS

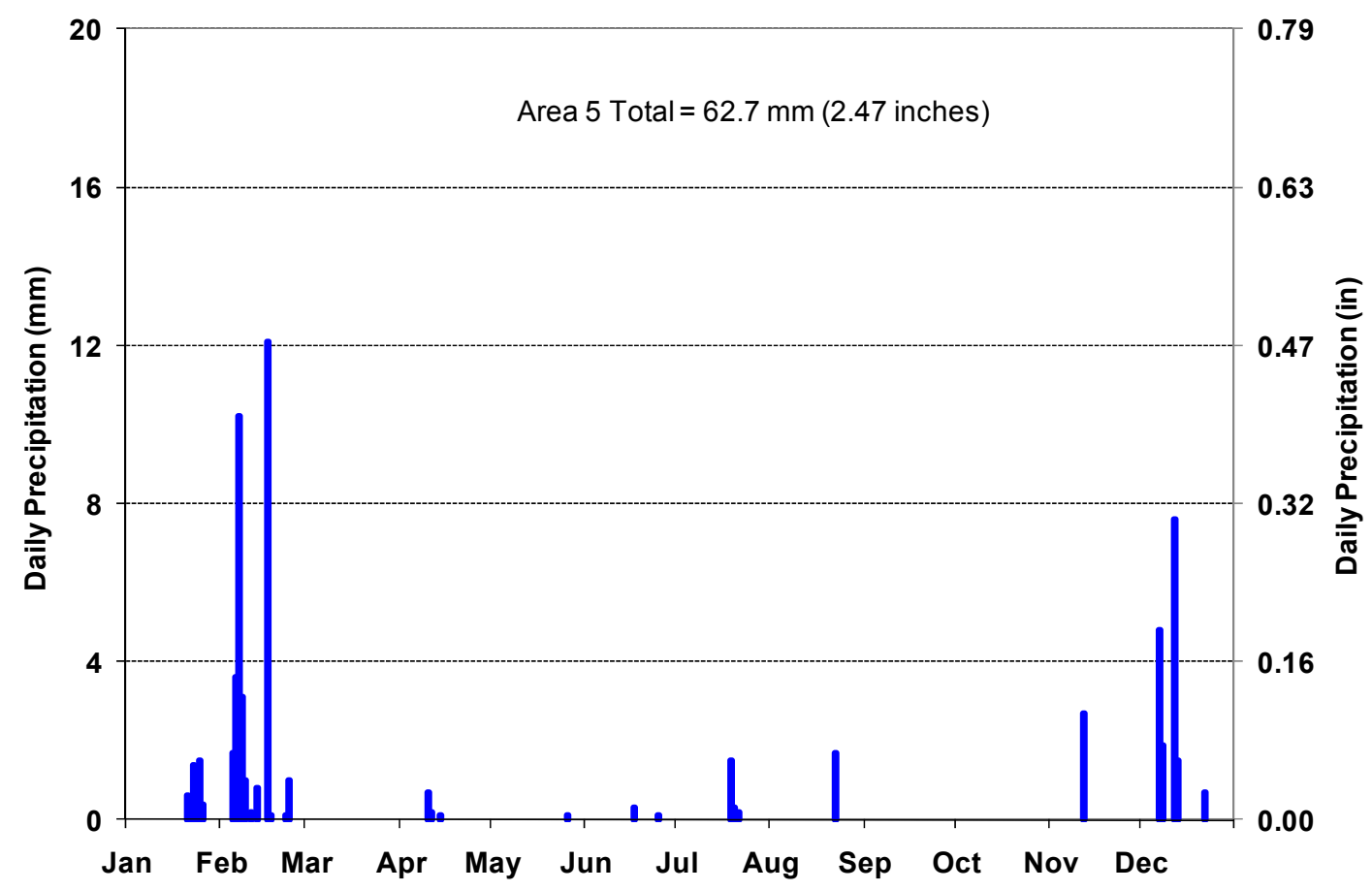

Figure 4-22 Daily Precipitation at the Area 5 RWMS 


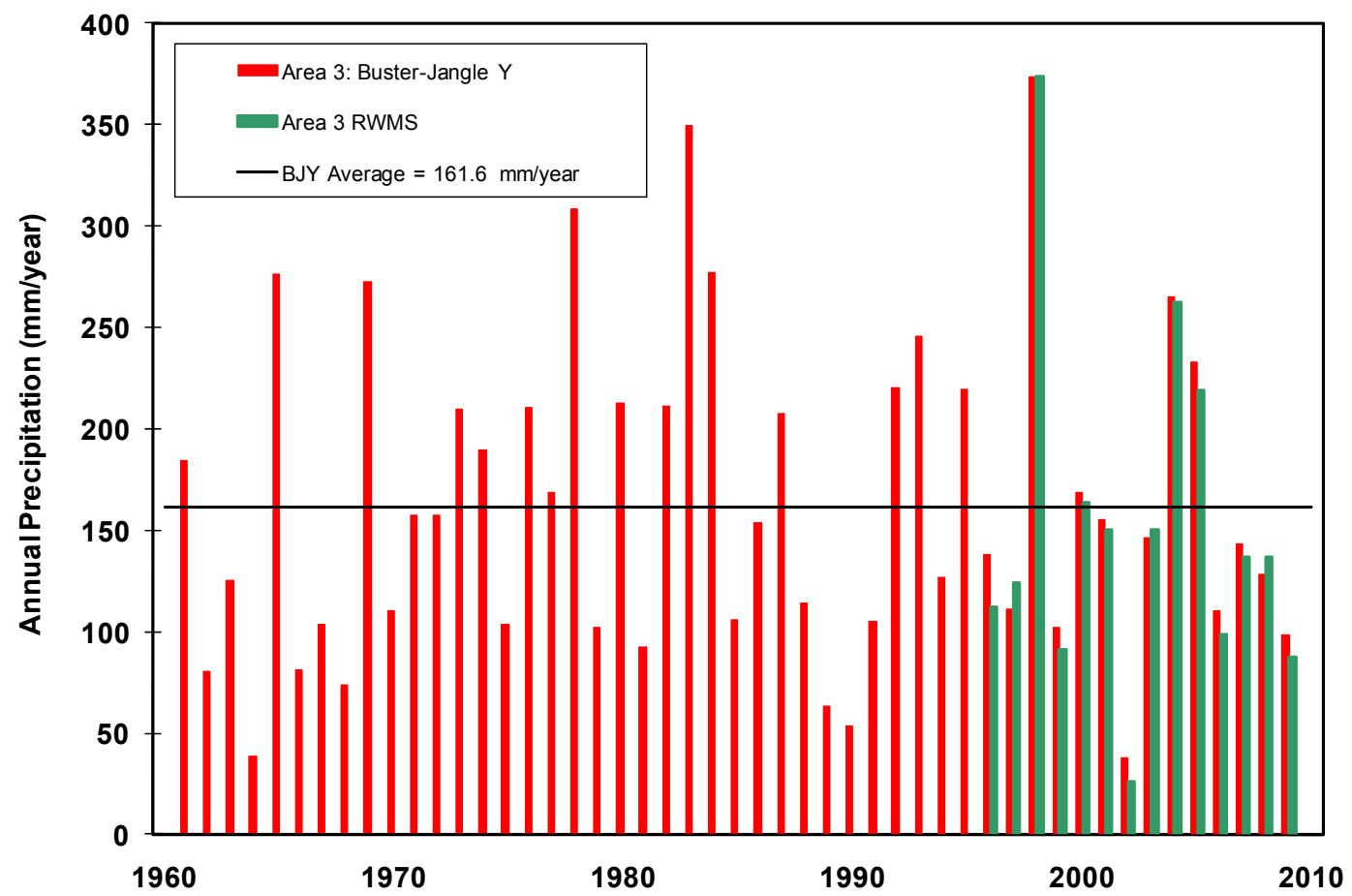

Figure 4-23 Historical Precipitation Record for Buster-Jangle $Y$ and the Area 3 RWMS

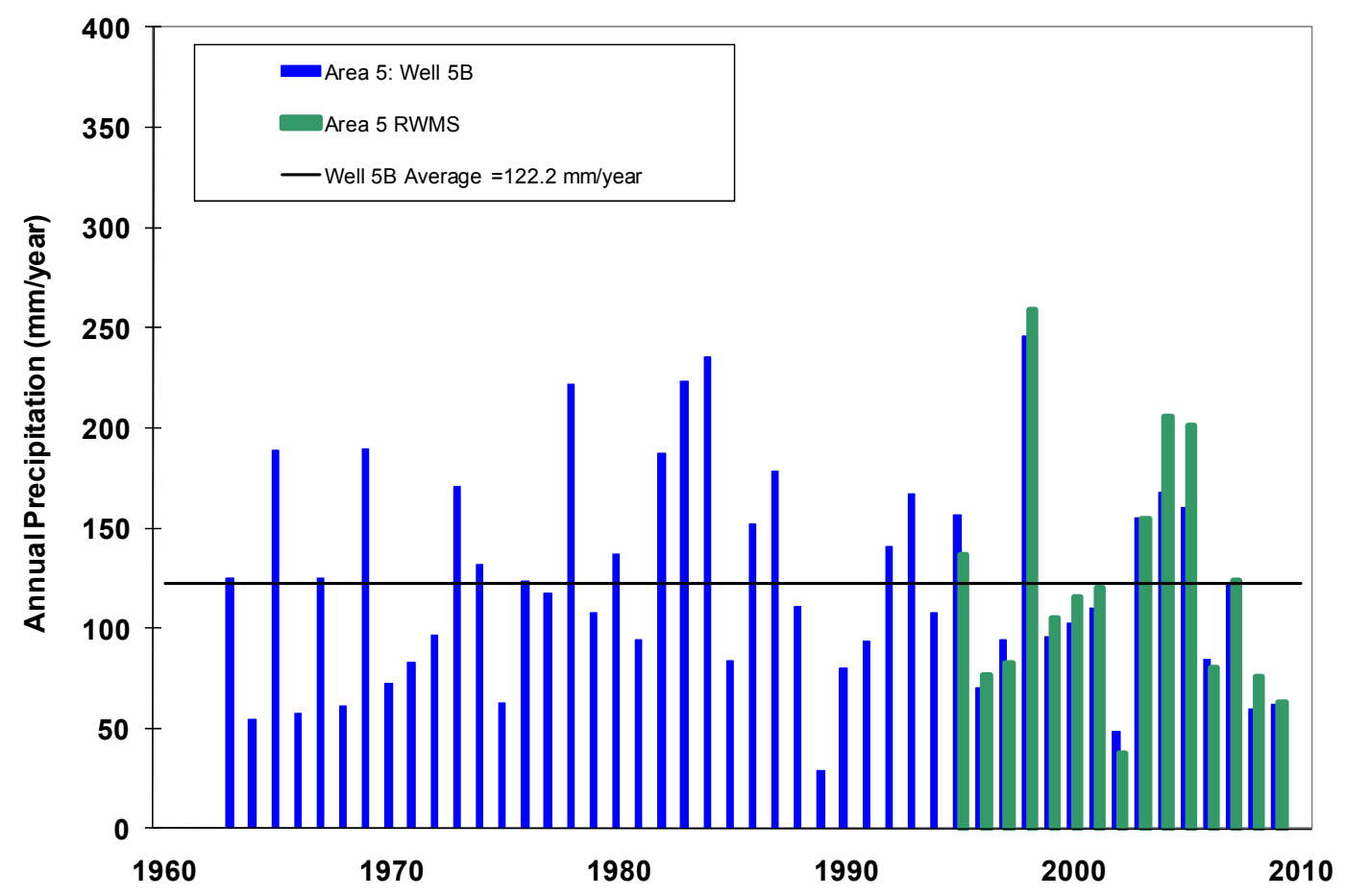

Figure 4-24 Historical Precipitation Record for Well 5B and the Area 5 RWMS 


\subsection{VADOSE ZONE MONITORING DATA}

\subsubsection{Monitoring Strategy}

Vadose zone monitoring is conducted at the Area 3 and Area 5 RWMSs to demonstrate compliance with DOE O 435.1 and confirm the assumptions in the PA for each RWMS (e.g., hydrologic conceptual models, including soil water contents, flux rates and directions, and volatile radionuclide releases). The vadose zone monitoring is also performed to detect changing trends in performance, provide added assurance to PA conclusions regarding facility performance, evaluate the performance of the operational monolayer waste covers, and confirm the PA performance objective of protecting groundwater resources.

The design of the current vadose zone monitoring program at the RWMSs is based on an understanding of the vadose zone system acquired through extensive characterization studies (BN, 1998; 2005a; 2005b; Blout et al., 1995; Reynolds Electrical \& Engineering Co., Inc., 1993a; 1993b; Shott et al., 1997; 1998; Tyler et al., 1996) and modeling studies (Levitt et al., 1999; Desotell et al., 2006; 2007). The objectives of the vadose zone monitoring program are accomplished, in part, by measuring water balances at each RWMS. Water balance studies involve using meteorology data to calculate $\mathrm{ET}_{\text {ref }}$ values (the driving force of upward flow), directly measuring ET and bare-soil E at the RWMS lysimeter facilities, and measuring soil water content and soil water potential in waste cell covers and floors using automated waste cover monitoring systems. The vadose zone monitoring strategy also evaluates the subsurface migration of tritium by sampling soil gas for the presence of tritium at borehole GCD-05 located near the center of Area 5 RWMS (see Figure 3-2).

\subsubsection{Soil Gas Tritium}

Soil gas tritium monitoring is conducted via soil gas sampling at borehole GCD-05. This $3.0 \mathrm{~m}$ (10 ft) diameter borehole has a large tritium inventory ( 2.2 million curies [Ci] at time of disposal) buried from 20 to $37 \mathrm{~m} \mathrm{(65} \mathrm{to} 120 \mathrm{ft}$ ) below ground surface. Two separate strings of nine soil gas sampling ports are buried in the borehole. The sampling ports are at depths of

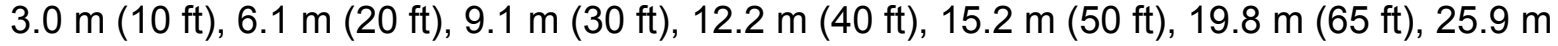
$(85 \mathrm{ft}), 33.5 \mathrm{~m}(110 \mathrm{ft})$, and $36.3 \mathrm{~m}(119 \mathrm{ft})$ below ground surface. Soil gas is pumped from the sampling ports to the surface at a low flow rate (2 cubic centimeters per minute). A cold trap removes water vapor from the air stream, and the tritium activity of the water is measured by liquid scintillation. Typically 25 liters of soil gas sample provide approximately 0.35 grams of water. Tritium sampling at borehole GCD-05 provides a direct measure of changes in tritium activity with depth due to degradation of waste containers and transport by advection and diffusion. Sampling started in 1990 and has continued at least annually through 2009.

Soil gas tritium was sampled from the nine GCD-05 sampling depths in July 2009. The 20-year trend in results indicates that upward migration of tritium through soil from the waste level is extremely slow. Tritium concentrations have remained constant and low from the surface down to $12.2 \mathrm{~m}$ (40 ft). Tritium concentrations at $15.2 \mathrm{~m}$ (50 ft) slowly increased through 1997 but then leveled off. The sample ports at depths of 19.8, 25.9, 33.5, and $36.3 \mathrm{~m}(65,85,110$, and $119 \mathrm{ft})$ are adjacent to the tritium source. Tritium concentrations at these depths have increased since 1990. The highest measured soil gas tritium concentration of 363.9 microcuries per cubic meter $\left(\mu \mathrm{Ci} / \mathrm{m}^{3}\right)$ indicates that most of the 2.2 million Ci originally buried at the site remains contained. Soil gas tritium concentrations with depth and time are illustrated in Figure 4-25 and Figure 4-26. 


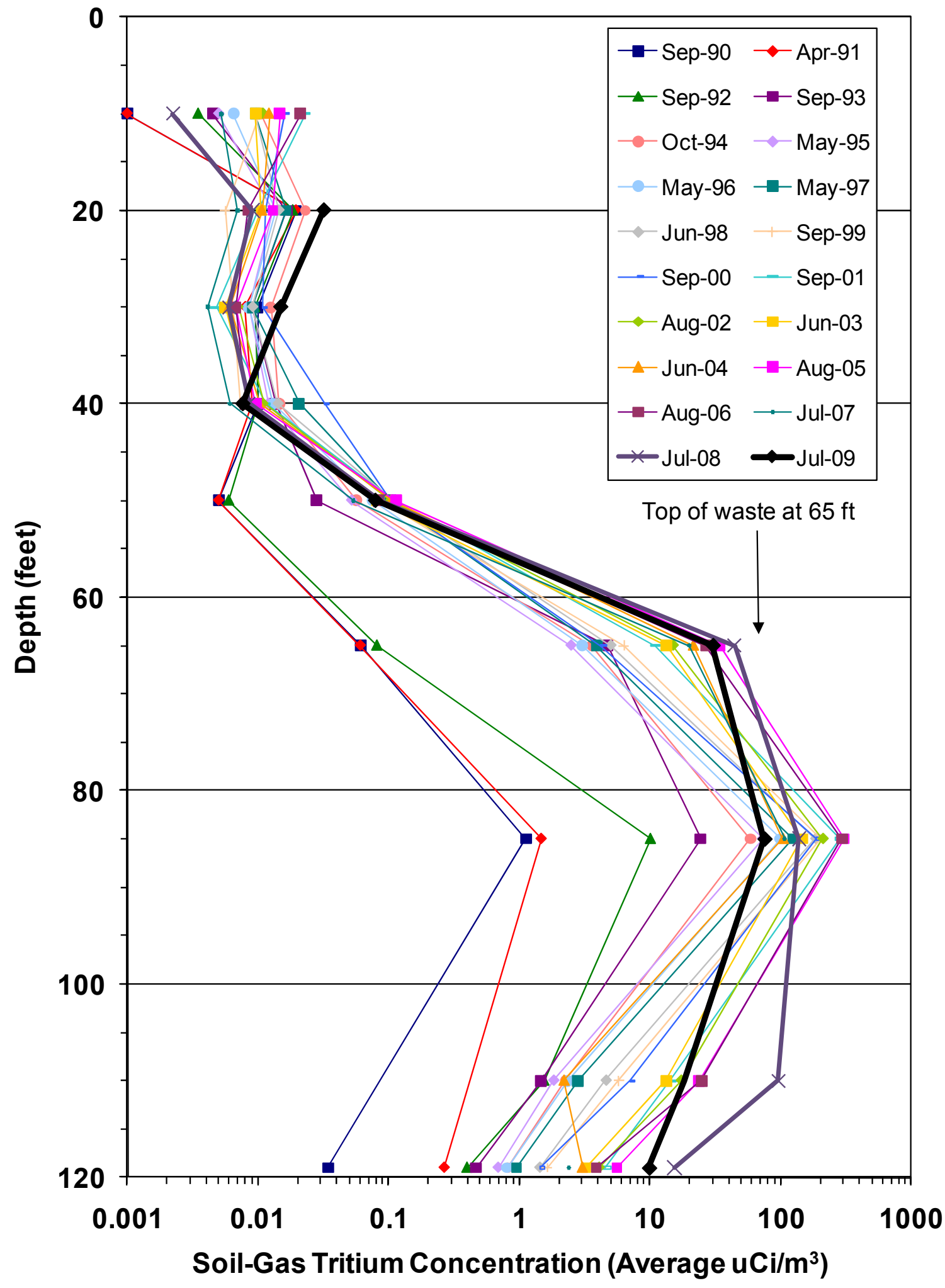

Figure 4-25 Soil-Gas Tritium Concentration Depth Profiles at GCD-05 

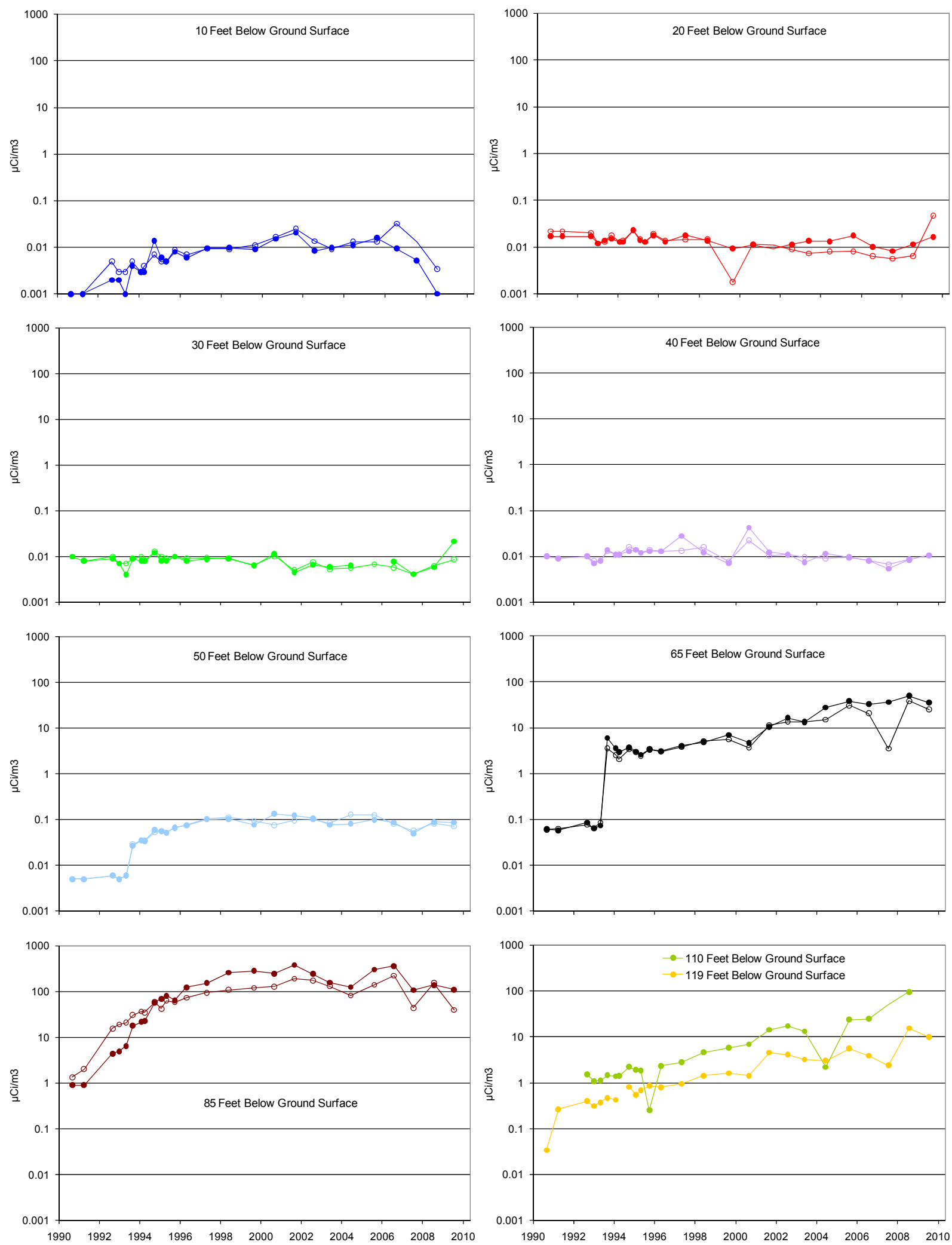

Figure 4-26 Soil-Gas Tritium Concentration for Each Depth at GCD-05 


\subsubsection{Area 5 Weighing Lysimeter Facility}

The Area 5 Weighing Lysimeter Facility consists of two precision weighing lysimeters located about $400 \mathrm{~m}(1,312 \mathrm{ft}$ ) southwest of the Area 5 RWMS (see Figure 3-2). Each lysimeter is a $2 \mathrm{~m}$ wide by $4 \mathrm{~m}$ long by $2 \mathrm{~m}$ deep ( $6.6 \mathrm{ft}$ wide by $13 \mathrm{ft}$ long by $6.6 \mathrm{ft}$ deep), open-top steel box filled with soil and mounted on a sensitive scale. Weight changes of each lysimeter are continuously monitored using an electronic load cell. Each load cell can measure approximately $0.1 \mathrm{~mm}$ (0.004 in.) of precipitation or ET. One lysimeter is vegetated with the native plant species Larrea tridentata (creosote bush), Lycium andersonii (Anderson's wolfberry), and Schismus arabicus (Arabian schismus) at the approximate density of the surrounding desert. The other lysimeter is kept bare to simulate the bare operational waste covers at the Area 5 RWMS. The load cells have provided an accurate data set of the surface water balance at the Area 5 RWMS since March 1994.

The weighing lysimeter data represent a simplified water balance: the change in soil water storage is equal to precipitation minus $\mathrm{E}$ (on bare lysimeters) or ET (on vegetated lysimeters). The water balance is simplified because no drainage can occur through the solid bottoms of the lysimeters and because a 2.5 centimeter $(\mathrm{cm})(1 \mathrm{in}$.) lip around the edge of the lysimeters prevents run-on and runoff. Total soil water storage for the period of March 30, 1994, through December 31, 2009, is illustrated in Figure 4-27.

The vegetated lysimeter is considerably drier than the bare-soil lysimeter, despite the small number of plants on the vegetated lysimeter (about 20 percent plant cover). The average soil water storage depth in the vegetated lysimeter from January 1, 1996, to December 31, 2009, is $115 \mathrm{~mm}$ (4.5 in.). This is equivalent to an average volumetric water content of 5.8 percent. For the same period, the average soil water storage depth in the bare lysimeter is $207 \mathrm{~mm}$ (8.1 in.), which is equivalent to an average volumetric water content of 10.4 percent. During 2009 the average soil water storage depth in the vegetated lysimeter was $119 \mathrm{~mm}$ (4.7 in.), and the average water storage depth in the bare lysimeter was $197 \mathrm{~mm}$ (7.8 in.).

Soil water storage decreases rapidly in the vegetated lysimeter following high rainfall periods due to ET. Typically, soil water decreases more slowly in the bare lysimeter due to E. Increases in soil water storage observed early in the data record in the vegetated lysimeter are a result of irrigation conducted to ensure survival of transplanted vegetation.

No water has ever accumulated at the bottom of the vegetated lysimeter. Heavy precipitation during the late fall and winter combined with low $E$ rates and higher initial water contents may result in water accumulation at the bottom of the bare lysimeter. A suction of $-8.0 \mathrm{kPa}(-1.2 \mathrm{PSI})$ was applied to the porous suction candles on the bottom of the bare lysimeter from May 5, 2008, to June 19, 2008, and from March 2, 2009, to May 12, 2009. No water effluent was collected from the suction candles during this period. Long-term numerical simulations (30 years) using a unit gradient bottom boundary were used to determine the amount of drainage that would have occurred if water could drain from the lysimeters. These simulations indicate an average of $1.0 \mathrm{~cm} / \mathrm{yr}$ of water reaches the bottom of the bare lysimeter and essentially no water reaches the bottom of the vegetated lysimeter (Desotell et al., 2006).

During 2009, E from the bare lysimeter was $85.0 \mathrm{~mm}$ (3.3 in.) and ET from the vegetated lysimeter was $74.5 \mathrm{~mm}$ (2.9 in.). Because both E and ET were greater than the $59.0 \mathrm{~mm}$ (2.3 in.) of precipitation at the Weighing Lysimeter Facility during 2009, water storage decreased in both lysimeters during 2009 (Figure 4-28). Precipitation exceeded both E and ET in February and December 2009, and ET exceeded E in April and May 2009 (Figure 4-29). 


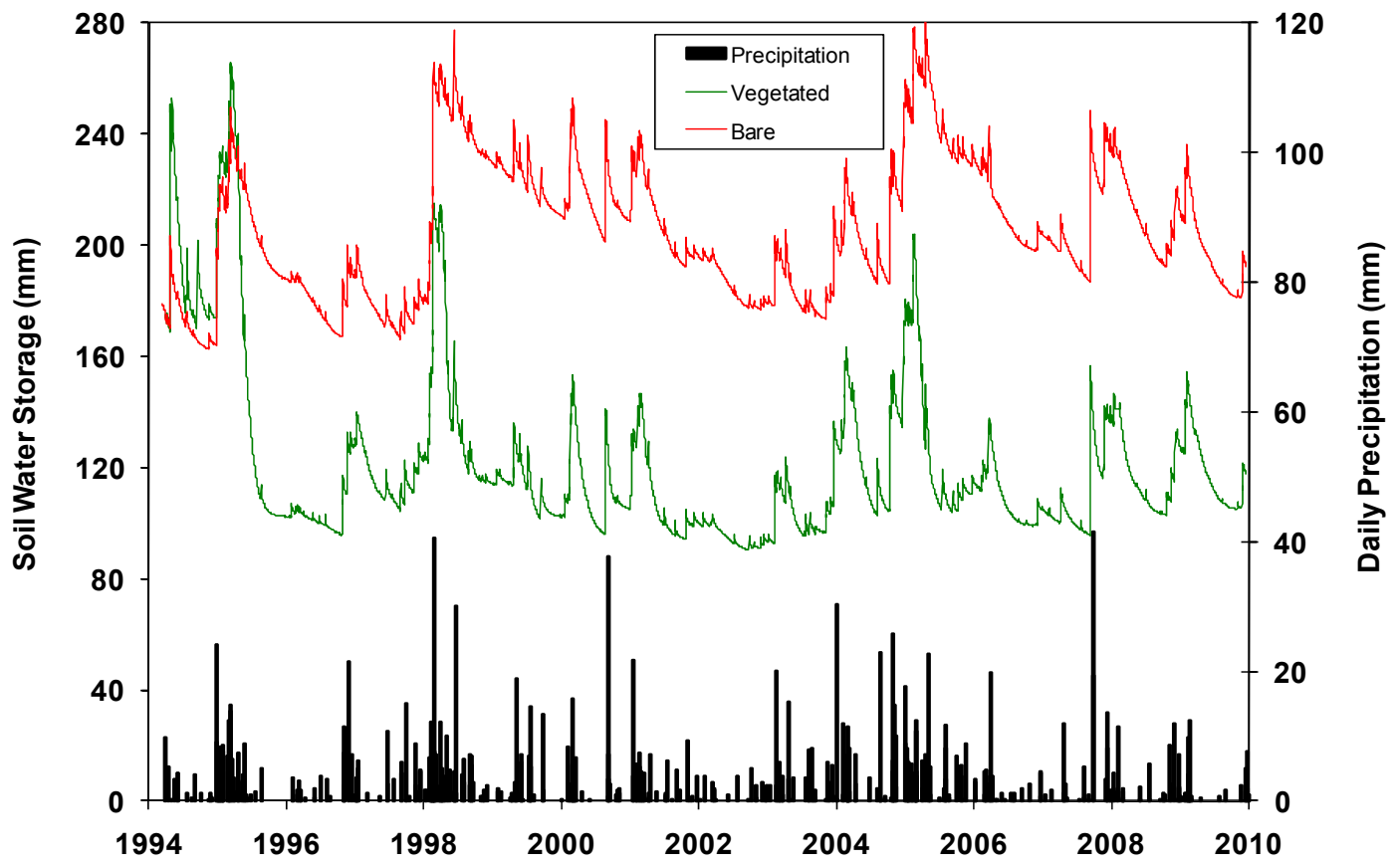

Figure 4-27 Weighing Lysimeter Data from March 1994 to December 2009

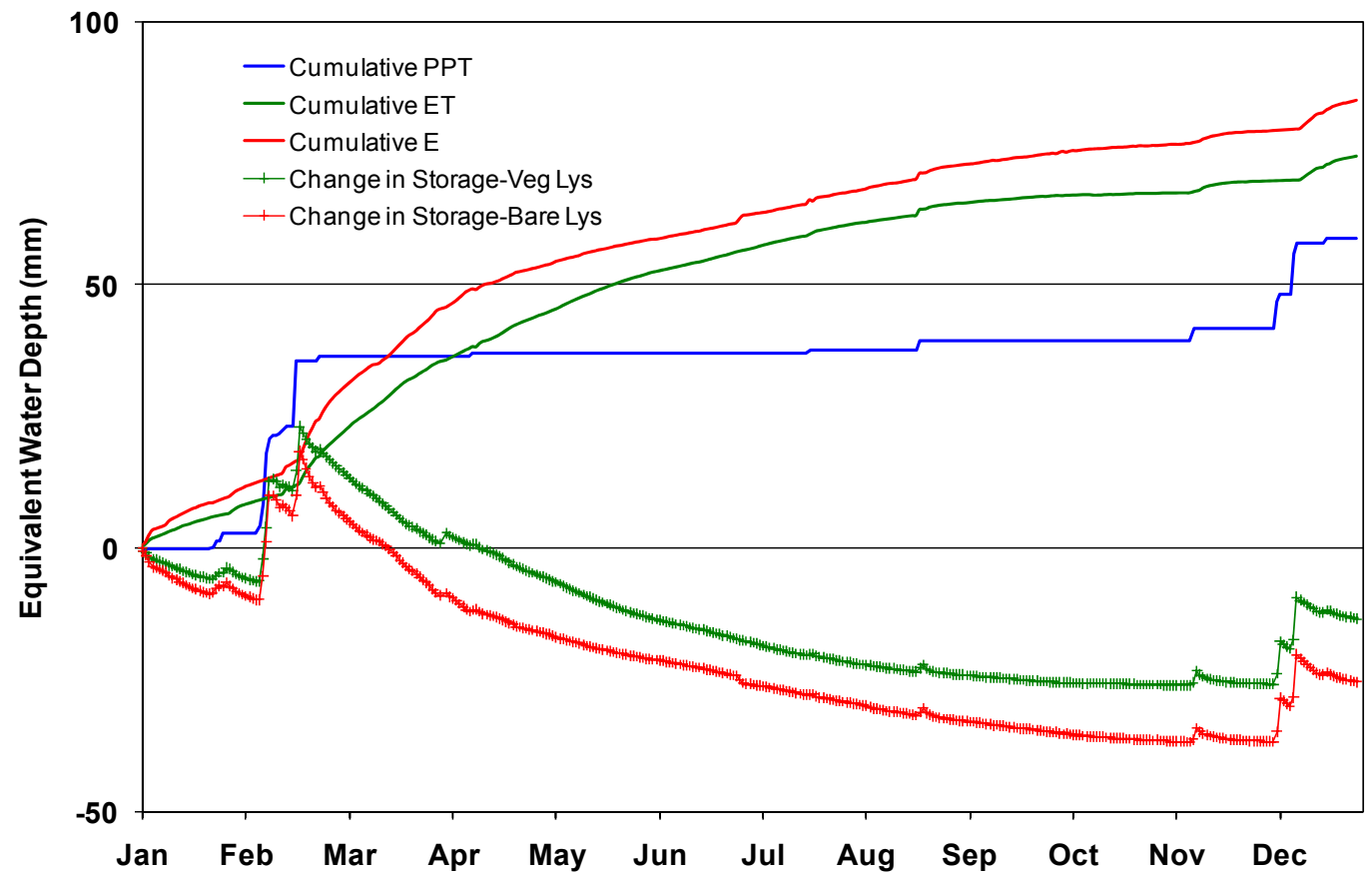

Figure 4-28 Precipitation, ET, E, and Storage for the Weighing Lysimeters during 2009 


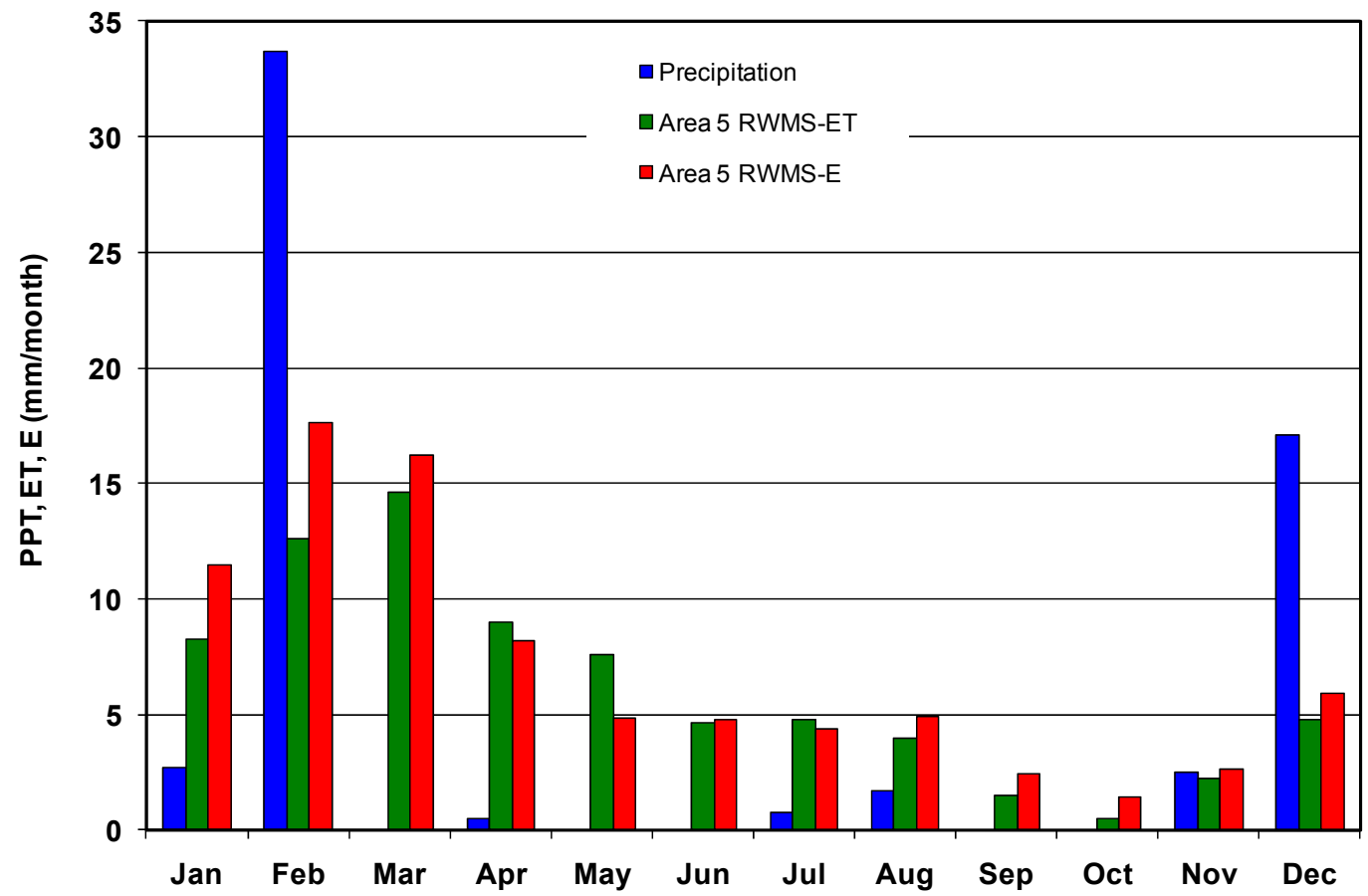

Figure 4-29 Monthly Precipitation, E, and ET during 2009

\subsubsection{Automated Waste Cover Monitoring System}

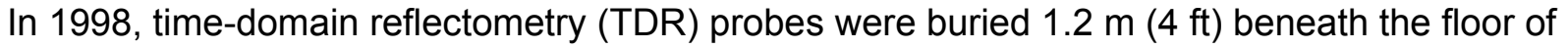
open Pit 5 at the Area 5 RWMS. The four probes are adjacent to the Pit $5 \mathrm{~N}$ and Pit $5 \mathrm{~S}$ monitoring locations with one probe buried near the Pit 5 center line and one probe near the

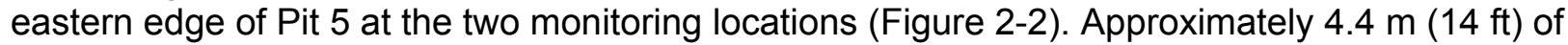

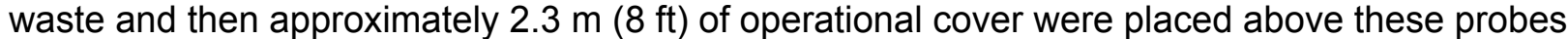
during disposal operations. The total depth of these probes is now approximately $7.9 \mathrm{~m}(26 \mathrm{ft})$. Measured volumetric water content in the floor of Pit 5 has remained constant at approximately 10 percent (Figure 4-30). The constant measured water content indicates that no moisture has percolated to $1.2 \mathrm{~m}(4 \mathrm{ft})$ below the waste.

In 1999, TDR probes were also installed in the operational cover of Pit 3 at monitoring locations Pit $3 \mathrm{~N}$ and Pit 3S (Figure 3-2). At each location probes were buried at depths ranging from 10 to $180 \mathrm{~cm}$ (0.3 to $5.9 \mathrm{ft}$ ). Precipitation events, beginning in October 2004, infiltrated into the operational cover and percolated below the deepest probe at $180 \mathrm{~cm}(5.9 \mathrm{ft})$ at both the north and south location in March 2005 (Figure 4-31). This moisture is below the range of substantial surface E. By September 2007, the volumetric water content at $180 \mathrm{~cm}(5.9 \mathrm{ft})$ at both sites had returned to approximately 12 percent. A $58.1 \mathrm{~mm}$ (2.29 in.) precipitation event occurred on September 21 and September 22, 2007. Water contents increased to $90 \mathrm{~cm}$ depth at Pit $3 \mathrm{~N}$ and to $120 \mathrm{~cm}$ depth at Pit $3 S$ after this storm. By May 2008, this moisture was removed from the Pit 3 operational cover by $E$ without any percolation below $120 \mathrm{~cm}$. Moisture contents at $150 \mathrm{~cm}$ and $180 \mathrm{~cm}$ depths had returned to the approximate moisture contents prior to October 2004 by December 2009 (Figure 4-31). 


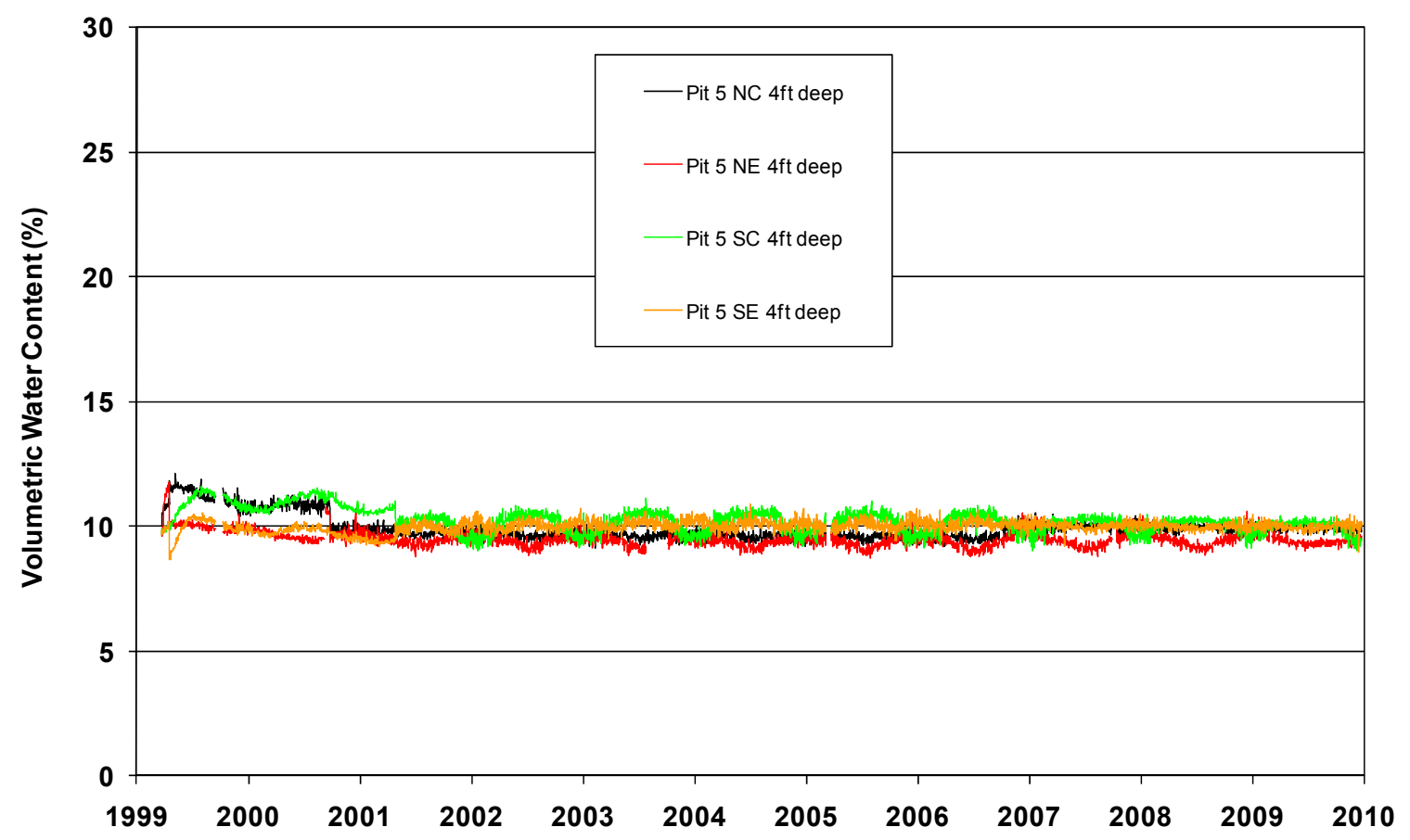

Figure 4-30 Soil Water Content in the Pit 5 Floor

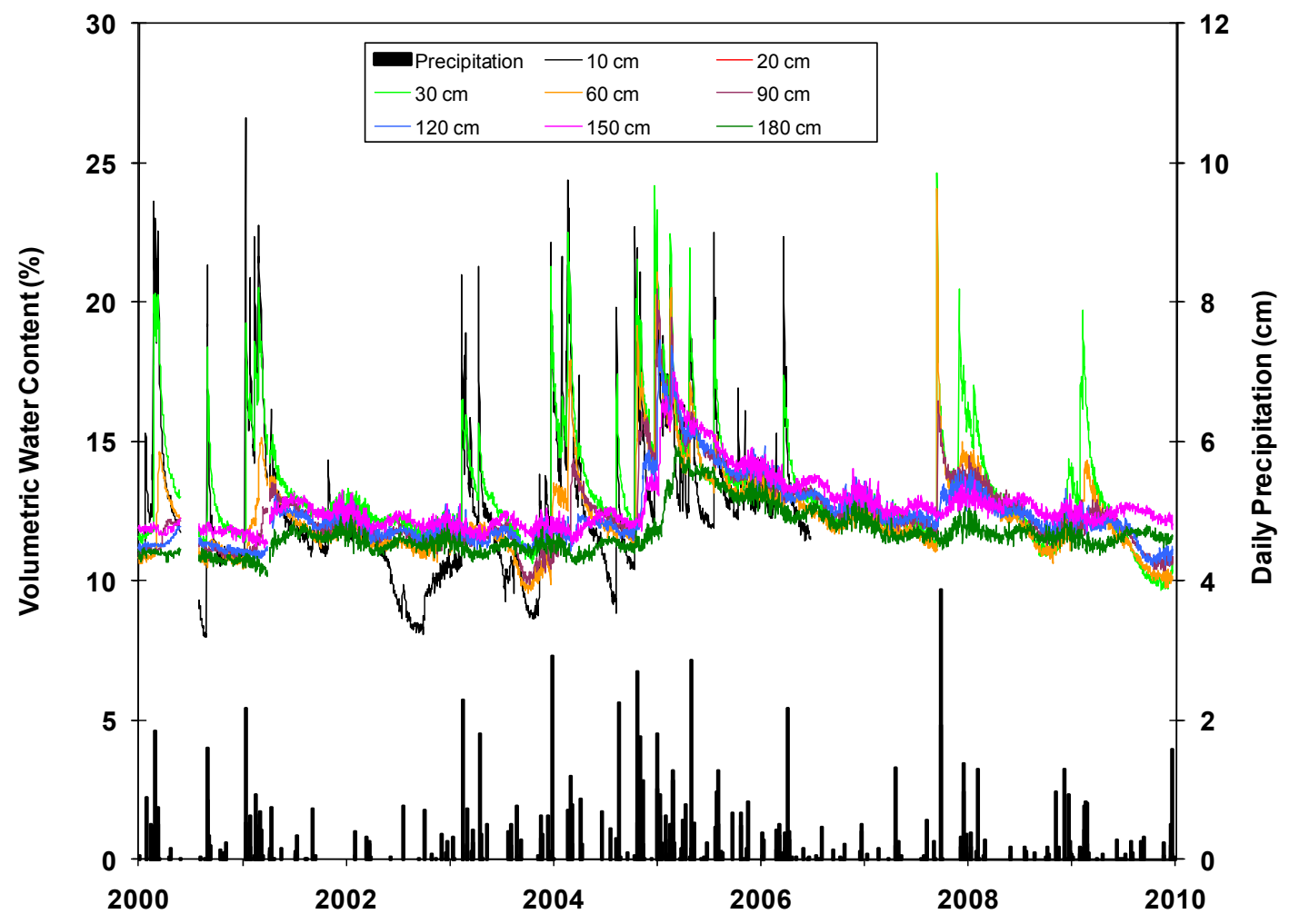

Figure 4-31 Soil Water Content in the Pit 3 Waste Cover at Pit $3 S$ 
In 2000, TDR probes were installed in the Pit 4 operational cover at location Pit $5 S$ and in the Pit 5 operational cover at Pit $5 \mathrm{~N}$ (Figure 3-2). At each location the probes are buried at depths ranging from 20 to $180 \mathrm{~cm}$ (0.7 to $5.9 \mathrm{ft}$ ). Precipitation events beginning in October 2004 infiltrated into the operational cover of Pit 4 and Pit 5, and percolated deeper than the deepest probe at $180 \mathrm{~cm}$ (5.9 ft) at Pit 4 in March 2005 and at Pit 5 in April 2005 (Figure 4-32). Because this moisture is below the range of substantial surface $E$, the gradual drying is most likely due to downward percolation. The $58.1 \mathrm{~mm}$ (2.29 in.) precipitation event on September 21 and September 22, 2007, increased water contents to $60 \mathrm{~cm}$ depth in both the Pit 4 and Pit 5 operational covers. Precipitation during January and February 2009 increased water contents to $90 \mathrm{~cm}$ depth in both the Pit 4 and Pit 5 operational covers (Figure 4-32).

In December 2000, TDR probes were installed in the final vegetated cover of the U-3ax/bl waste disposal unit at the Area 3 RWMS (Figure 3-1). Eight vertically arranged TDR probes were installed at four locations at depths ranging from 30 to $244 \mathrm{~cm}$ (1 to $8 \mathrm{ft}$ ). Measured soil water content values for one location (East Nest A) in the U-3ax/bl waste cover are shown in Figure 4-33. From 2001 to 2005, the TDR data indicate that the soil water content in the cover generally decreased over time as the vegetation on the cover grew. The precipitation events beginning in October 2004 infiltrated into the final cover of U-3ax/bl, but the moisture has been removed without percolating below the $244 \mathrm{~cm}(8 \mathrm{ft})$ deep sensor. Unlike the bare-soil operational covers on Pit 3, Pit 4, and Pit 5, the moisture at U-3ax/bl was removed by ET before reaching $244 \mathrm{~cm}$ (8 ft). The wetting front from $6.6 \mathrm{~cm}$ (2.6 in.) precipitation event on September 21 and September 22, 2007, only reached $30 \mathrm{~cm}(1 \mathrm{ft})$ deep as compared to 90 to $120 \mathrm{~cm}$ ( 3 to $4 \mathrm{ft}$ ) deep in the bare operational covers. Initial water contents are lower in the vegetated $U-3 a x / b l$ cover, so more moisture is stored per unit depth as the wetting front moves down. Vegetation is critical to the effectiveness of the U-3ax/bl cover. In the native environment, about 12 percent of the surface area is covered by plant material. Obtaining 12 percent vegetative cover on the soil caps is dependent upon the seed germination success and seedling survival of native plants seeded or transplanted onto the cover. A quantitative analysis of the vegetative cover on the U-3ax/bl cover is conducted annually in the spring. The percent cover for the established $U-3 a x / b l$ cover has ranged from 20.2 percent in 2005, to 19.6 percent in 2006 , to 10.6 percent in 2007 , to 26.8 percent in 2008 , to 12.2 percent in 2009 . The dominant perennial plant on the U-3ax/bl cover is Atriplex confertifolia (shadscale saltbush), which accounted for 11.6 percent cover. 


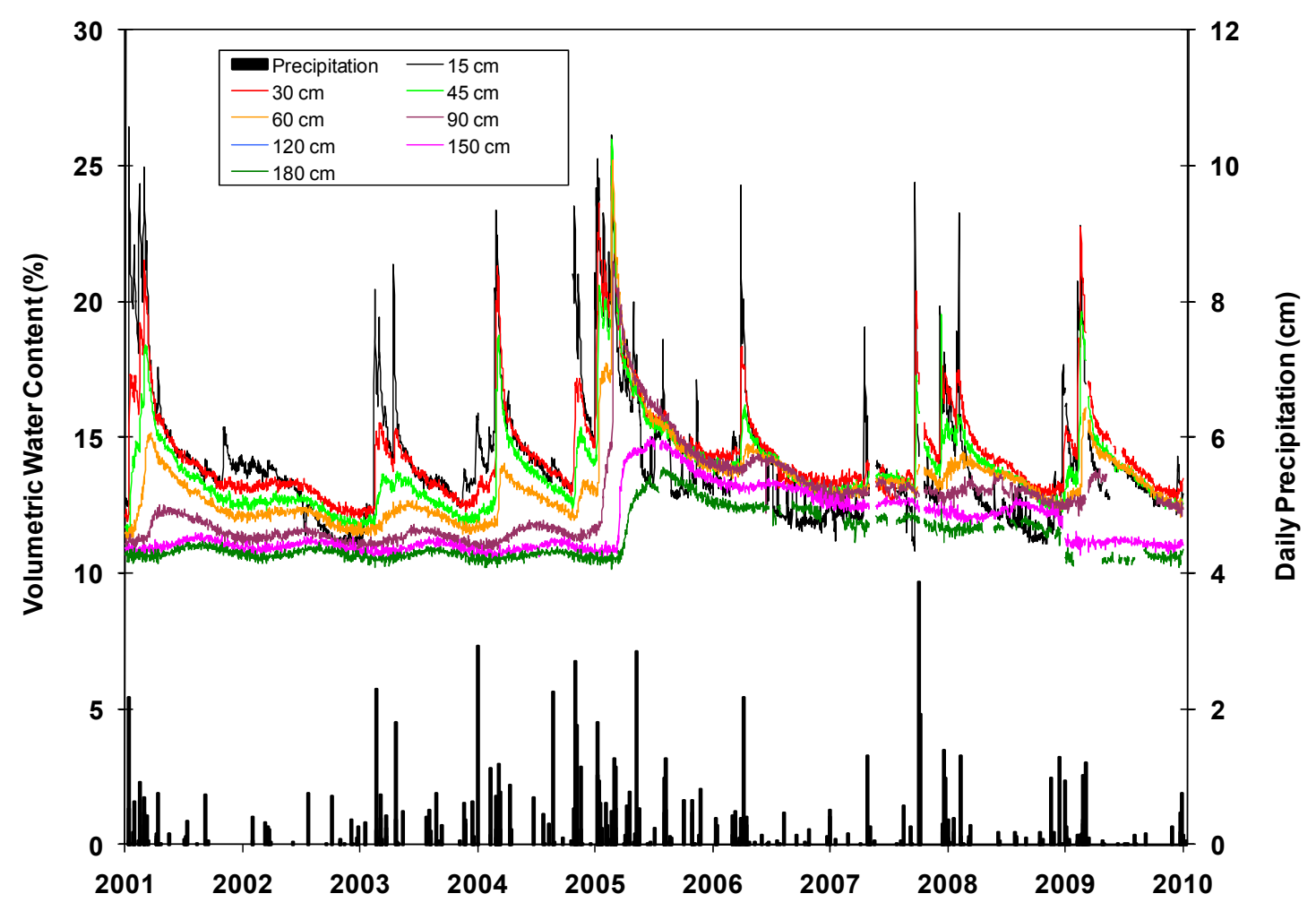

Figure 4-32 Water Content in the Pit 5 Waste Cover at Pit 5N

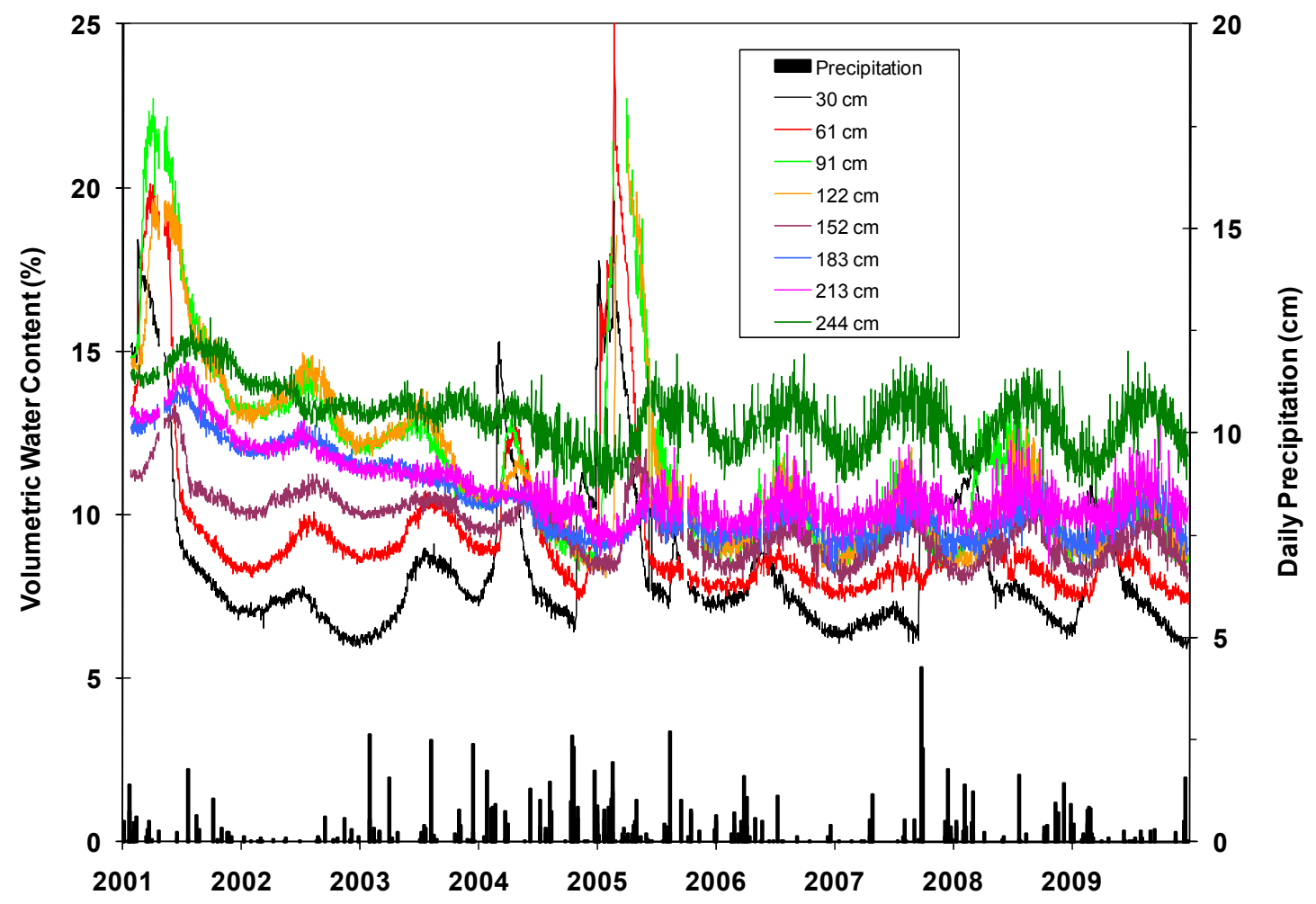

Figure 4-33 Soil Water Content in the U-3ax/bl Cover 


\subsubsection{Area 3 Drainage Lysimeter Facility}

The Area 3 Drainage Lysimeter Facility is immediately northwest of the U-3ax/bl waste disposal unit at the Area 3 RWMS (Figure 3-1). This facility is designed to collect saturated gravity drainage from eight $3.05 \mathrm{~m}(10 \mathrm{ft})$ diameter by $2.44 \mathrm{~m}(8 \mathrm{ft})$ deep lysimeters. Each lysimeter is filled with native soil and packed to mimic the U-3ax/bl soil cover. Each lysimeter has eight TDR probes to measure moisture content depth profiles, paired with eight heat dissipation probes to measure soil water potential depth profiles. The probes are installed at $7.6 \mathrm{~cm}(0.25 \mathrm{ft}), 15 \mathrm{~cm}$ $(0.5 \mathrm{ft}), 30 \mathrm{~cm}(1 \mathrm{ft}), 61 \mathrm{~cm}(2 \mathrm{ft}), 91 \mathrm{~cm}(3 \mathrm{ft}), 122 \mathrm{~cm}(4 \mathrm{ft}), 183 \mathrm{~cm}(6 \mathrm{ft})$, and $244 \mathrm{~cm}(8 \mathrm{ft})$ deep. Measured water content values at the bottom of the lysimeters and drainage from the lysimeters provide an indirect measure of potential drainage from the U-3ax/bl soil cover. The lysimeter facility was constructed to fulfill data needs including reducing uncertainty in the expected performance of monolayer-ET closure covers under various surface vegetation treatments and climatic change scenarios such as increased rainfall.

There are three surface vegetation treatments subject to two climate treatments on the lysimeters. The three surface vegetation treatments are bare-soil, invader species (primarily Bromus tectorum [cheatgrass] and Halogeton glomeratus [halogeton]), and native species (primarily Atriplex confertifolia [shadscale saltbush], Krascheninnikovia lanata [winterfat], Ephedra nevadensis [Nevada jointfir], Achnatherum hymenoides [Indian ricegrass], and Elymus elymoides [squirreltail grass]). The climate treatments are natural precipitation and 3 times natural precipitation. The 3 times natural precipitation lysimeters receive natural precipitation and are irrigated with an amount equal to 2 times natural precipitation.

The eight lysimeters are identified as Lysimeter $\mathrm{A}$ through Lysimeter $\mathrm{H}$. Lysimeter $\mathrm{A}$ is bare soil with natural precipitation, Lysimeter $B$ is bare soil with 3 times natural precipitation, Lysimeter $C$ is invader species with natural precipitation, Lysimeter $D$ is invader species with 3 times natural precipitation, Lysimeters $E$ and $G$ are native species with natural precipitation, and Lysimeters $F$ and $\mathrm{H}$ are native species with 3 times natural precipitation. The 2009 precipitation at the Drainage Lysimeters was $90 \mathrm{~mm}$ (3.5 in.). The 2009 irrigation applied to Lysimeters B, D, F, and $\mathrm{H}$ is $181 \mathrm{~mm}$ (7.1 in.). The 2009 lysimeter treatments are summarized in Table 2.

There were 921 liters (243 gallons) of drainage from Lysimeter B during 2009. The equivalent depth of this drainage is $12.6 \mathrm{~cm}$ (5.0 in.). This drainage occurred from January 1,2009 , to August 17, 2009, and is 46 percent of total precipitation and applied irrigation. There was no drainage from any other lysimeter during 2009. Drainage has only occurred from the irrigated lysimeters. Total cumulative drainage from each irrigated lysimeter is $93.1 \mathrm{~cm}(36.7 \mathrm{in}$.) from Lysimeter B, $5.8 \mathrm{~cm}$ (2.3 in.) from Lysimeter D, $29.3 \mathrm{~cm}$ (11.5 in.) from Lysimeter F, and $12.3 \mathrm{~cm}$ (4.8 in.) from Lysimeter $\mathrm{H}$ (Figure 4-34).

Cover was measured for each of the eight drainage lysimeters on May 13, 2009. The results are summarized in Table 3. B. tectorum accounts 34.4 percent cover on Lysimeter D, 15.6 percent cover on Lysimeter E, 50.0 percent cover on Lysimeter $F$, and 18.7 percent cover on Lysimeter $\mathrm{H}$. Dead $B$. tectorum accounts for much of the litter percent cover. 
Table 2 Area 3 Drainage Lysimeter Treatments in 2009

\begin{tabular}{||clcccc||}
\hline \hline Lysimeter & \multicolumn{1}{c}{ Climate } & $\begin{array}{c}\text { Precipitation } \\
(\mathrm{mm})\end{array}$ & $\begin{array}{c}\text { Irrigation } \\
(\mathrm{mm})\end{array}$ & $\begin{array}{c}\text { Drainage } \\
(\mathrm{mm})\end{array}$ & Surface Vegetation \\
\hline A & Natural precipitation & 90 & 0 & 0 & Bare-soil \\
B & 3 times natural precipitation & 90 & 181 & 126 & Bare-soil \\
C & Natural precipitation & 90 & 0 & 0 & Invader species \\
D & 3 times natural precipitation & 90 & 181 & 0 & Invader species \\
E & Natural precipitation & 90 & 0 & 0 & Native species \\
F & 3 times natural precipitation & 90 & 181 & 0 & Native species \\
G & Natural precipitation & 90 & 0 & 0 & Native species \\
H & 3 times natural precipitation & 90 & 181 & 0 & Native species \\
\hline \hline
\end{tabular}

Table 3 Area 3 Drainage Lysimeters Percent Cover

\begin{tabular}{||ccccc||}
\hline \hline Lysimeter & $\begin{array}{c}\text { Plant Cover } \\
\text { (percent) }\end{array}$ & $\begin{array}{c}\text { Bare } \\
\text { (percent) }\end{array}$ & $\begin{array}{c}\text { Gravel } \\
\text { (percent) }\end{array}$ & $\begin{array}{c}\text { Litter } \\
\text { (percent) }\end{array}$ \\
\hline A & 0.0 & 40.6 & 59.4 & 0.0 \\
B & 0.0 & 37.5 & 53.1 & 9.4 \\
C & 3.1 & 46.9 & 37.5 & 12.5 \\
D & 34.4 & 0.0 & 0.0 & 65.6 \\
E & 18.8 & 3.1 & 0.0 & 78.1 \\
F & 87.5 & 0.0 & 0.0 & 12.5 \\
G & 3.1 & 12.5 & 0.0 & 84.4 \\
H & 78.1 & 0.0 & 0.0 & 21.9 \\
\hline \hline
\end{tabular}

Figure 4-35 shows the total water storage for all eight lysimeters from 2004 through 2009. Water storage is calculated using TDR data. The two bare-soil lysimeters (Lysimeters A and B) have the highest water storage. Evaporation and drainage are the only processes that remove water from these lysimeters. Water storage in the other irrigated lysimeters (Lysimeters $D, F$, and $H$ ) was elevated at the beginning of 2009. Until the early summer, ET removed some of this water. When the $B$. tectorum died in early summer, the ET on Lysimeter D stopped. The perennial shrubs and grasses on Lysimeters $\mathrm{F}$ and $\mathrm{H}$ continued ET during the summer, and most of this water was removed from these two lysimeters by the end of summer. 


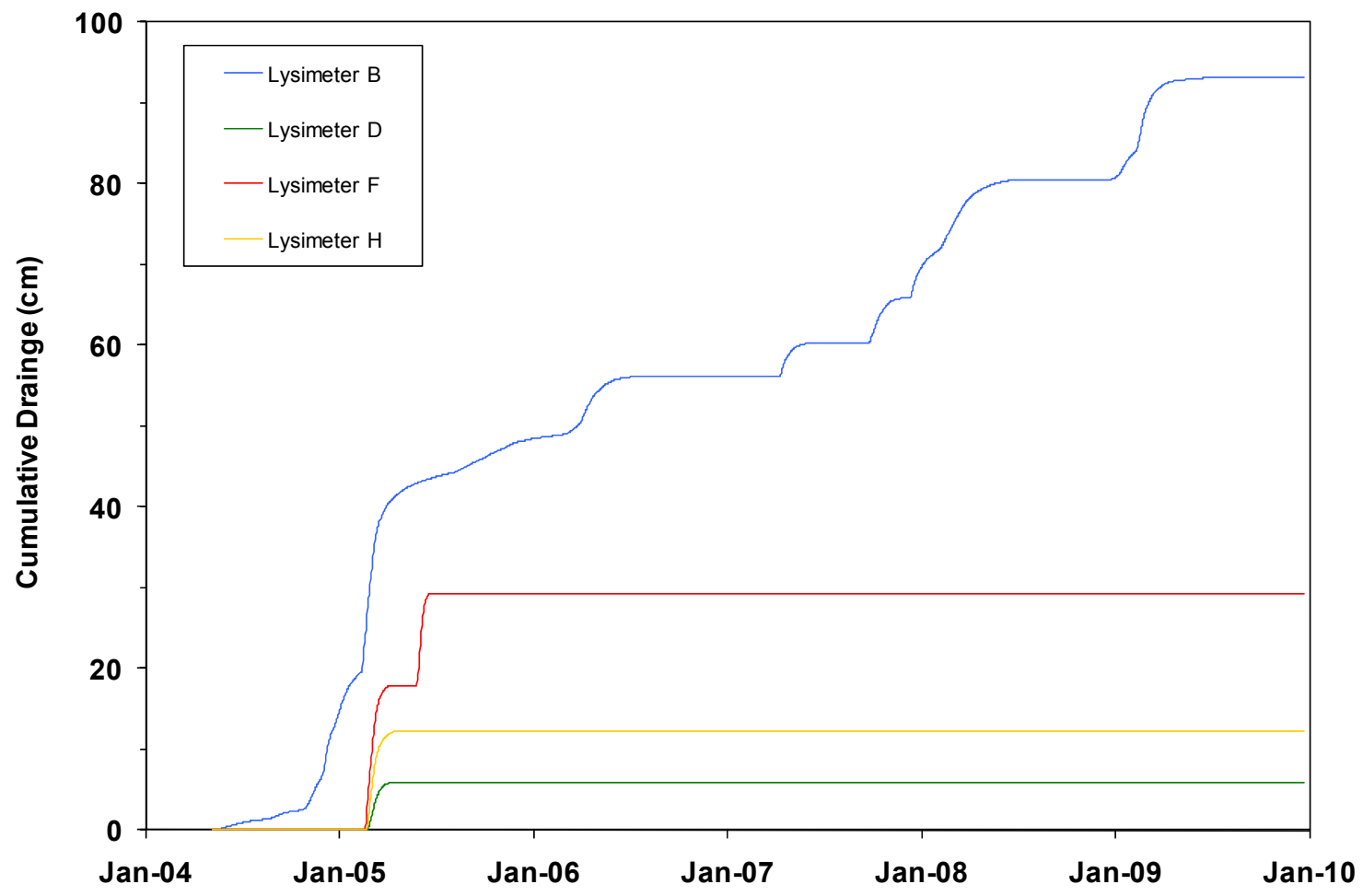

Figure 4-34 Cumulative Drainage from the Drainage Lysimeters

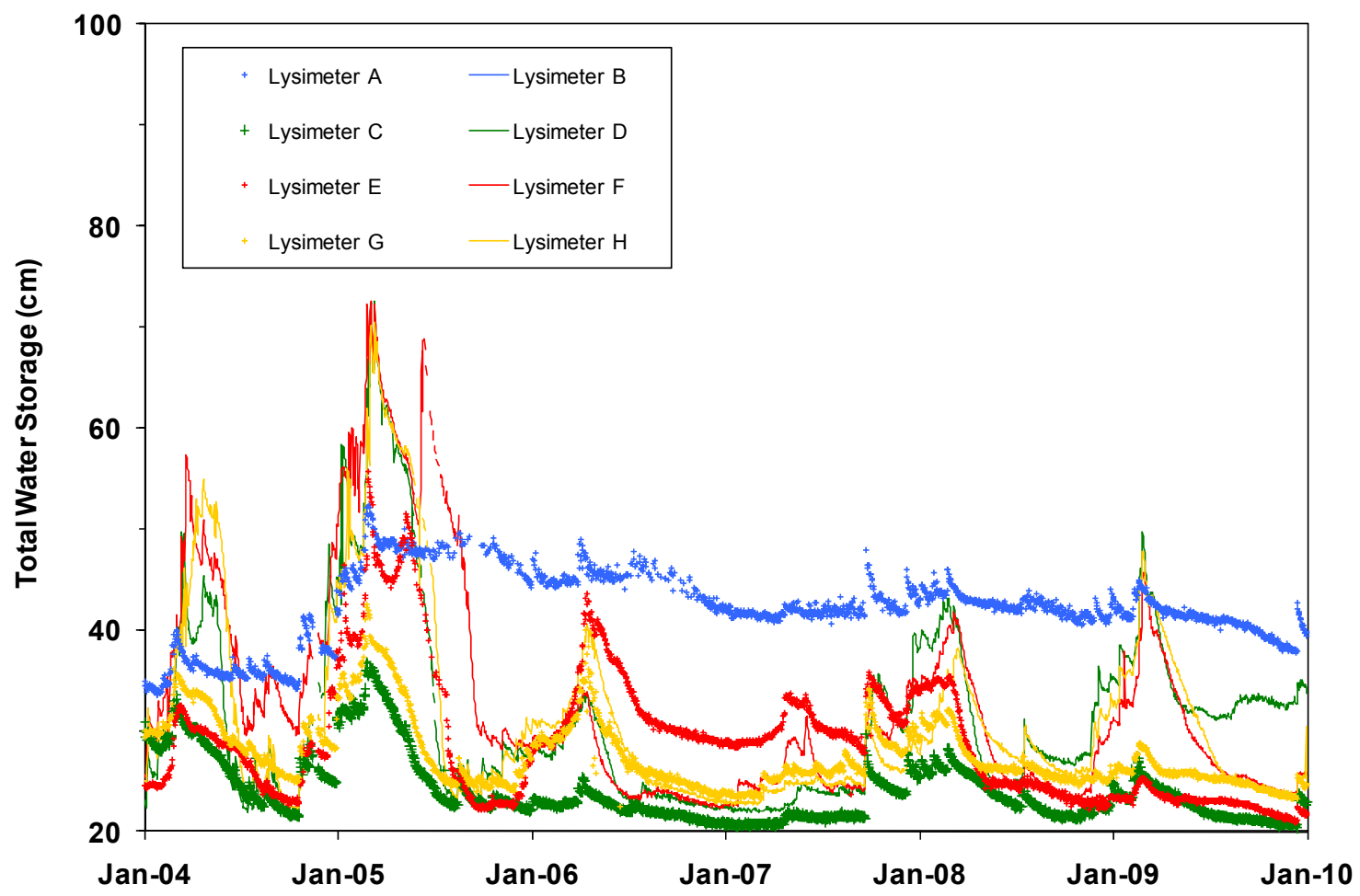

Figure 4-35 Soil Water Storage in the Drainage Lysimeters 


\subsection{WASTE COVER SUBSIDENCE}

Subsidence monitoring is conducted to ensure that subsidence features are repaired to prevent the development of preferential water migration pathways through the waste covers.

Subsidence monitoring also helps ensure that vadose zone monitoring data are representative of the entire RWMS. Typically as small depressions or cracks are observed in the covers, they are filled before large subsidence features develop. No large subsidence features were observed during 2009.

\subsection{BIOTA MONITORING DATA}

Plant and animal (biota) monitoring at the Area 3 RWMS and Area 5 RWMS help characterize and define trends in potential transport of radionuclides from buried waste and provide data to help demonstrate that projected releases of radionuclides to the environment are maintained within limits in the PA required by DOE O 435.1. Tritium is the predominant radionuclide observed due to its high mobility as tritiated water. The primary mechanisms that transport tritium upward through waste covers and into the atmosphere are gaseous diffusion and advection, bioturbation, plant uptake and transpiration, and evaporation from the soil surface. Sampling water from plants and animals living on waste covers provides a direct measure of tritium uptake. Analysis of plant and animal tissues for gamma-emitting radionuclides, ${ }^{90} \mathrm{Sr}$, and alpha-emitting radionuclides provides information on potential biotic intrusion into the waste and uptake of radionuclides.

Biota and soil sampling took place August 31, 2009, through October 4, 2009. Three plants, eight small mammals (composited into three samples), and three samples of soil excavated by small mammals or ants were sampled from the U-3ax/bl cover inside the Area 3 RWMS (Table 4 and Figure 4-36). Three plants, five small mammals (composited into two samples), and three soil samples from small mammal burrows or ant nests were sampled from the Area 5 RWMS (Table 4 and Figure 4-37). A composite sample of plants, small mammals, and animal excavated soil was also collected from a control location outside each of the Area 3 and Area 5 RWMS (Table 4). The control location for the Area 3 RWMS was approximately $50 \mathrm{~m}(164 \mathrm{ft})$ north of the northwest corner of the RWMS. The control location for the Area 5 RWMS was at the Weighing Lysimeter Facility in Area 5.

Water was extracted from biota samples by distillation, and tritium concentration was measured by liquid scintillation. Tritium concentrations are displayed in Figure 4-36 and Figure 4-37 and are listed in Table 5 and Table 6 . There are no tritium results for soil samples because no water was extracted from the soil samples due to very low water contents. Soil and dried tissue samples were analyzed for gamma-emitting radionuclides, ${ }^{90} \mathrm{Sr},{ }^{241} \mathrm{Am}$, and plutonium. Results from these analyses are listed in Table 5, Table 6, and Table 7.

Tritium was detected in all RWMS biota samples, and tritium concentrations were much higher than any other detected radionuclide. Concentrations of tritium in vegetation and animals at the Area 5 RWMS are higher than tritium measured in soil moisture evaporating at the surface (Figure 4-6). This suggests the concentration of tritium in soil moisture in the root zone of these plants is higher than that at the soil surface but does not necessary indicate roots have penetrated the waste zone. Concentrations of tritium in small mammals are likely higher due to the animals feeding on vegetation.

Two radionuclides other than tritium, ${ }^{239+240} \mathrm{Pu}$ in one plant sample and ${ }^{152} \mathrm{Eu}$ in one soil sample, from the Area 5 RWMS were slightly higher than those measured at the Area 5 RWMS control 
site (Table 5 and Table 7). Plant and animal samples from the U3ax/bl cover had more radionuclide detections and generally higher concentrations than control samples(Table 5 and Table 6) except for those in the control soil sample, which had relatively high concentrations of ${ }^{137} \mathrm{Cs},{ }^{238} \mathrm{Pu},{ }^{239+240} \mathrm{Pu}$, and ${ }^{241} \mathrm{Am}$ (Table 7). Nearby historical atmospheric nuclear testing is likely the source for elevated concentrations in the control site soil.

Figure 4-38 presents 11 years of plant tritium data from the Area 3 and Area 5 RWMS. Because limited small mammal sampling has occurred on the RWMS, only tritium data from 2005 through 2009 are available (Figure 4-39). High variability within years and concentrations ranging over multiple orders of magnitude between samples within each year, make differences between years negligible. Based on this data, there is no evidence that plants or animals have intruded into the waste or that waste significantly moved to where it is accessible to plants or animals.

Table 4 Biota Samples collected during 2009

\begin{tabular}{|c|c|c|}
\hline Sample & Location & Description \\
\hline \multicolumn{3}{|l|}{ Plants } \\
\hline ATCO & Area 3 RWMS & Atriplex confertifolia (shadscale saltbush) \\
\hline ATCA & Area 3 RWMS & Atriplex canescens (fourwing saltbush) \\
\hline KRLA & Area 3 RWMS & Krascheninnikovia lanata (winterfat) \\
\hline SAPA & Area 5 RWMS & Salsola paulsenii (Russian thistle) \\
\hline Atriplex Spp. \#1 & Area 5 RWMS & Atriplex species (saltbush) \\
\hline Atriplex Spp. \#2 & Area 5 RWMS & Atriplex species (saltbush) \\
\hline Salsola Spp. & Area 3 Control & Composite of 3 Salsola species (Russian thistle) \\
\hline LATR/Atriplex Spp. & Area 5 Control & $\begin{array}{l}\text { Composite of } 1 \text { Larrea tridentate (creosote) and } 2 \\
\text { Atriplex species (saltbush) }\end{array}$ \\
\hline \multicolumn{3}{|l|}{ Animals } \\
\hline Composite \#1 & Area 3 RWMS & Composite of 4 kangaroo rats \\
\hline Composite \#2 & Area 3 RWMS & Composite of 2 antelope ground squirrels \\
\hline Composite \#3 & Area 3 RWMS & $\begin{array}{l}\text { Composite of } 1 \text { kangaroo rat and } 1 \text { antelope } \\
\text { ground squirrel }\end{array}$ \\
\hline Composite \#1 & Area 5 RWMS & Composite of 2 kangaroo rats \\
\hline Composite \#2 & Area 5 RWMS & Composite of 3 kangaroo rats \\
\hline Composite \#1 & Area 3 Control & Composite of 2 kangaroo rats and 3 deer mice \\
\hline Composite \#1 & Area 5 Control & Composite of 4 kangaroo rats \\
\hline
\end{tabular}




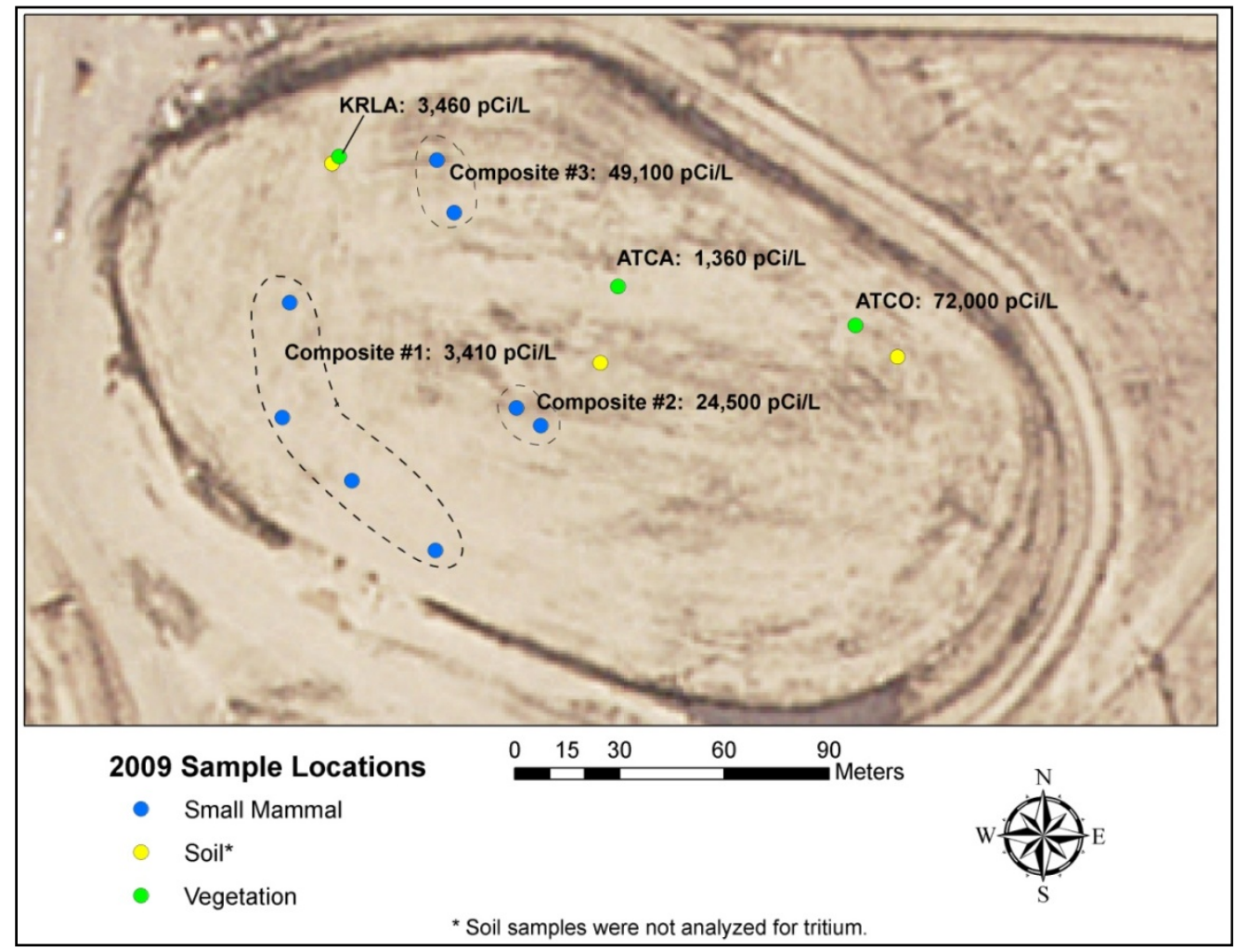

Figure 4-36 Area 3 RWMS Biota and Soil Sample Locations and Tritium Results (pCi/L)

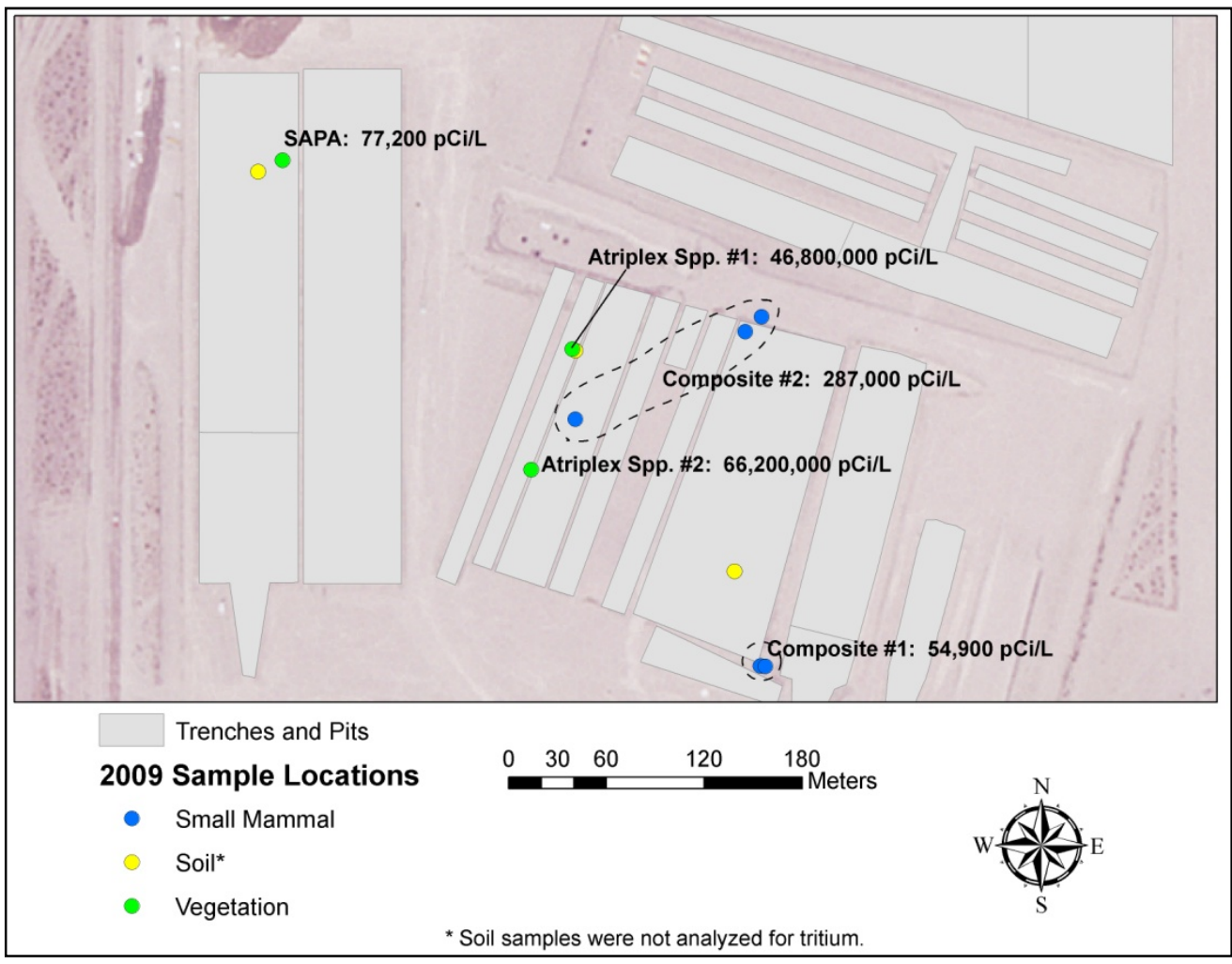

Figure 4-37 Area 5 RWMS Biota and Soil Sample Locations and Tritium Results (pCi/L) 


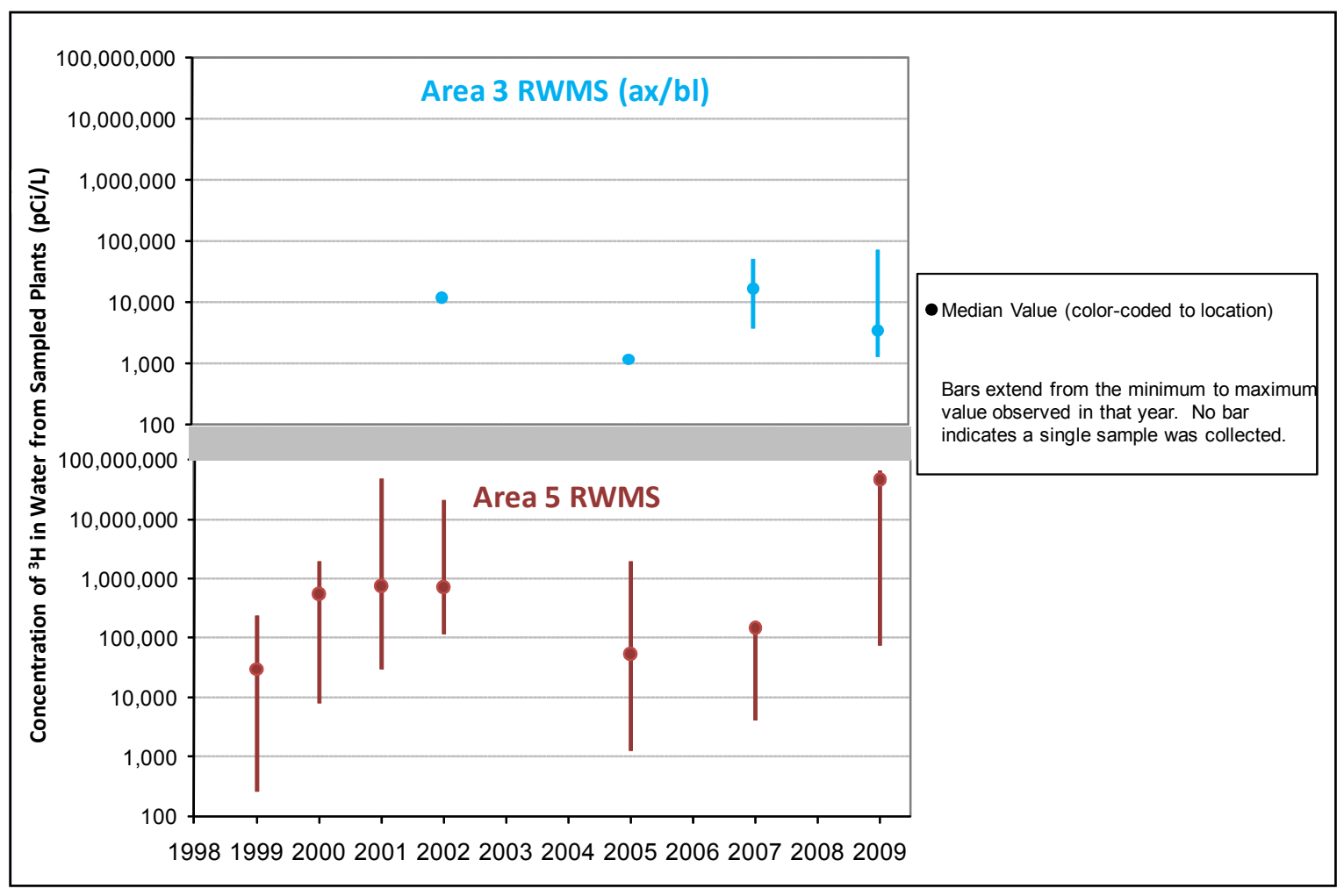

Figure 4-38 Tritium Concentrations in RWMS Vegetation, 1999-2009

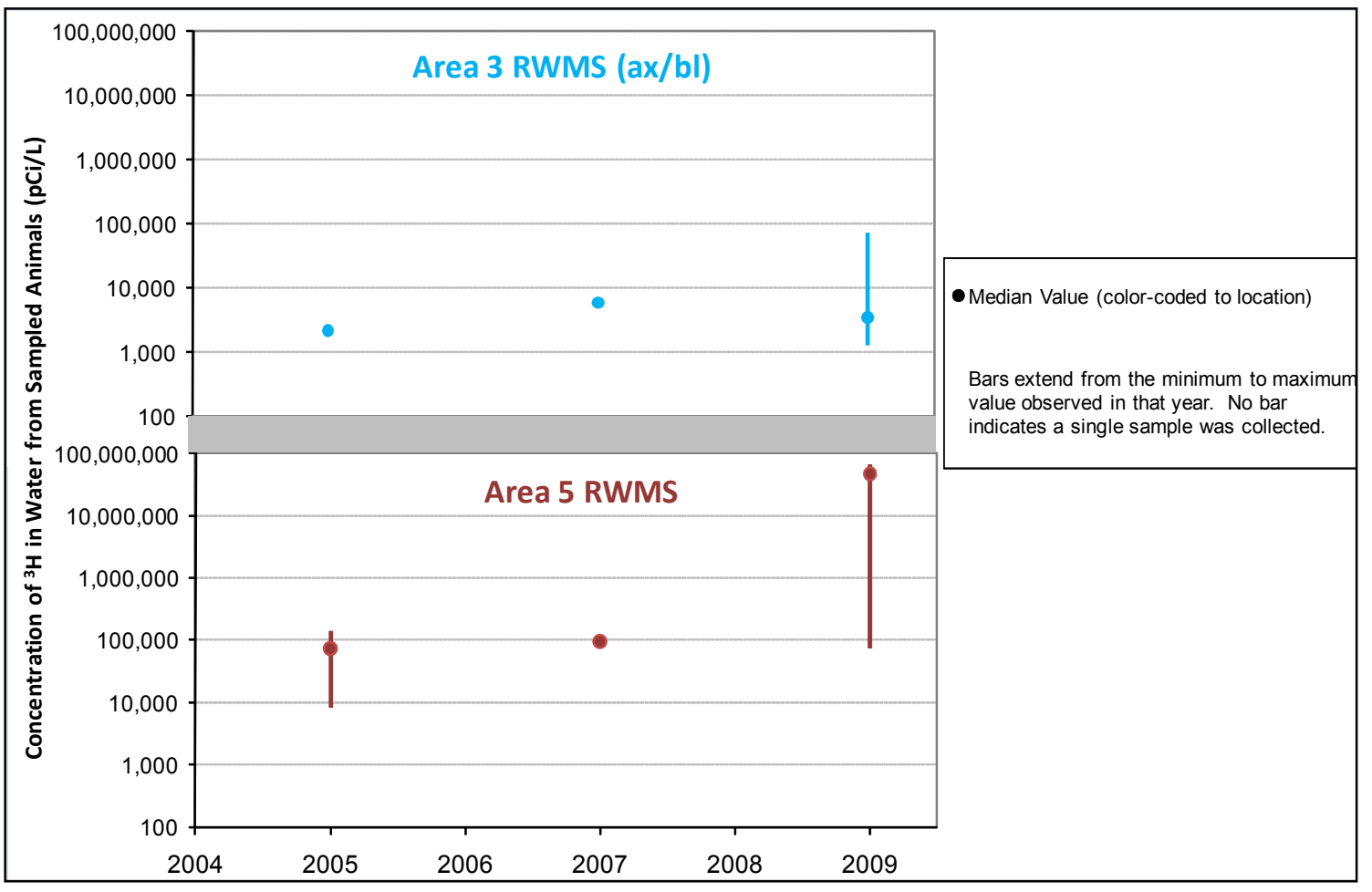

Figure 4-39 Tritium Concentrations in RWMS Animals, 2005-2009 
Table 5 Radionuclide Results for Plant Samples collected in 2009

\begin{tabular}{|c|c|c|c|c|}
\hline \multicolumn{5}{|c|}{ Radionuclide Concentrations \pm Uncertainty $^{(\text {a) }}$} \\
\hline & ${ }^{3} \mathrm{H}(\mathrm{pCi} / \mathrm{L})^{(\mathrm{b})}$ & ${ }^{137} \mathrm{Cs}(\mathrm{pCi} / \mathrm{g})^{(\mathrm{c})}$ & ${ }^{239+240} \mathrm{Pu}(\mathrm{pCi} / \mathrm{g})^{(\mathrm{c})}$ & ${ }^{241} \mathrm{Am}(\mathrm{pCi} / \mathrm{g}){ }^{(\mathrm{c})}$ \\
\hline \multicolumn{5}{|l|}{ Area 3 RWMS ax/bl } \\
\hline ATCA & $1,360 \pm 312$ & $0.163 \pm 0.098$ & $0.002 \pm 0.006$ & $-0.001 \pm 0.006$ \\
\hline ATCO & $\pm 7,340$ & $-0.00527 \pm 0.045$ & $0.0772 \pm 0.032$ & $0.0013 \pm 0.005$ \\
\hline KRLA & $3,460 \pm 499$ & $-0.008 \pm 0.080$ & $0.047 \pm 0.025$ & $0.010 \pm 0.013$ \\
\hline$\%$ Above MDC (Average MDC): & $100 \%(383)$ & $33.3 \%(0.093)$ & $66.6 \%(0.012)$ & $0 \%(0.013)$ \\
\hline \multicolumn{5}{|l|}{ Area 5 RWMS } \\
\hline Atriplex Spp. \#1 & $46,800,000 \pm 4,720,000$ & $0.022 \pm 0.042$ & $0.027 \pm 0.018$ & $0.005 \pm 0.007$ \\
\hline Atriplex Spp. \#2 & $66,200,000 \pm 6,710,000$ & $-0.005 \pm 0.035$ & $-0.001 \pm 0.006$ & $-0.002 \pm 0.005$ \\
\hline SAPA & $77,200 \pm 7,860$ & $0.018 \pm 0.059$ & $0.000 \pm 0.005$ & $-0.002 \pm 0.006$ \\
\hline$\%$ Above MDC (Average MDC): & $100 \%(1,1901)$ & $0 \%(0.075)$ & $33.3 \%(0.013)$ & $0 \%(0.011)$ \\
\hline \multicolumn{5}{|l|}{ Area 3 Control } \\
\hline Salsola Spp. & $38 \pm 216$ & $0.064 \pm 0.101$ & $0.008 \pm 0.009$ & $0.003 \pm 0.007$ \\
\hline$\%$ Above MDC (Average MDC): & $0 \%(378)$ & $0 \%(0.064)$ & $0 \%(0.008)$ & $0 \%(0.016)$ \\
\hline \multicolumn{5}{|l|}{ Area 5 Control } \\
\hline LATR/Atriplex Spp. Composite & \multirow{2}{*}{$0 \%(380)$} & $-0.016 \pm 0.044$ & $0.001 \pm 0.006$ & $0.001 \pm 0.005$ \\
\hline$\%$ Above MDC (Average MDC): & & $0 \%(0.016)$ & $0 \%(0.016)$ & $0 \%(0.012)$ \\
\hline
\end{tabular}

Green-shaded results are greater than the sample-specific MDC

(a) \pm 2 standard deviations

(b) picocuries per liter water from sample

(c) picocuries per gram dry weight of sample 
Table 6 Radionuclide Results for Animal Samples collected in 2009

\begin{tabular}{|c|c|c|c|c|c|}
\hline \multicolumn{6}{|c|}{ " Radionuclide Concentrations \pm Uncertainty ${ }^{(a)}$} \\
\hline & \multicolumn{2}{|c|}{${ }^{3} \mathrm{H}(\mathrm{pCi} / \mathrm{L})^{(\mathrm{b})}$} & \multicolumn{3}{|c|}{${ }^{239+240} \mathrm{Pu}(\mathrm{pCi} / \mathrm{g})^{(\mathrm{c})}$} \\
\hline \multicolumn{6}{|l|}{ Area 3 RWMS ax/bl } \\
\hline Composite \#1 & 3,410 & 491 & 0.038 & \pm & 0.021 \\
\hline Composite \#2 & 24,500 & 2,580 & 0.075 & \pm & 0.031 \\
\hline Composite \#3 & 49,100 & 5,030 & 0.036 & \pm & 0.021 \\
\hline$\%$ Above MDC (Average MDC): & \multicolumn{2}{|c|}{$100 \%(353)$} & \multicolumn{3}{|c|}{$100 \%(0.013)$} \\
\hline \multicolumn{6}{|l|}{ Area 5 RWMS } \\
\hline Composite \#1 & 54,900 & $\pm \quad 5,610$ & -0.002 & \pm & 0.007 \\
\hline Composite \#2 & 287,000 & $\pm 29,200$ & 0.007 & \pm & 0.010 \\
\hline$\%$ Above MDC (Average MDC): & \multicolumn{2}{|c|}{$100 \%(536)$} & \multicolumn{3}{|c|}{$0 \%(0.017)$} \\
\hline \multicolumn{6}{|l|}{ Area 3 RWMS Control } \\
\hline Composite \#1 & 166 & 225 & 0.065 & \pm & 0.029 \\
\hline$\%$ Above MDC (Average MDC): & \multicolumn{2}{|c|}{$0 \%(380)$} & \multicolumn{3}{|c|}{$100 \%(0.009)$} \\
\hline \multicolumn{6}{|l|}{ Area 5 RWMS Control } \\
\hline Composite \#1 & 114 & 221 & 0.003 & \pm & 0.006 \\
\hline$\%$ Above MDC (Average MDC): & \multicolumn{2}{|c|}{$0 \%(379)$} & \multicolumn{3}{|c|}{$0 \%(0.009)$} \\
\hline
\end{tabular}

Green-shaded results are considered detected (results greater than the sample-specific MDC).

(a) \pm 2 standard deviations

(b) picocuries per liter water from sample

(c) picocuries per gram dry weight of sample 
Table 7 Radionuclide Results for Soil Samples collected in 2009

\begin{tabular}{|c|c|c|c|c|c|c|}
\hline \multicolumn{7}{|c|}{ "Radionuclide Concentrations \pm Uncertainty ${ }^{(a)}$} \\
\hline & ${ }^{137} \mathrm{Cs}(\mathrm{pCi} / \mathrm{g}){ }^{(\mathrm{c})}$ & ${ }^{152} \mathrm{Eu}(\mathrm{pCi} / \mathrm{g})^{(\mathrm{c})}$ & ${ }^{155} \mathrm{Eu}(\mathrm{pCi} / \mathrm{g})^{(\mathrm{c})}$ & ${ }^{238} \mathrm{Pu}(\mathrm{pCi} / \mathrm{g})^{(\mathrm{c})}$ & ${ }^{239+240} \mathrm{Pu}(\mathrm{pCi} / \mathrm{g})^{(\mathrm{c})}$ & ${ }^{241} \mathrm{Am}(\mathrm{pCi} / \mathrm{g})^{(\mathrm{c})}$ \\
\hline \multicolumn{7}{|l|}{ Area 3 RWMS ax/bl } \\
\hline Ant Mound \#1 & $0.0340 \pm 0.0424$ & $-0.0584 \pm 0.1160$ & $0.0292 \pm 0.1150$ & $-0.0019 \pm 0.0031$ & $0.0627 \pm 0.0161$ & $0.0120 \pm 0.0118$ \\
\hline Ant Mound \#2 & $0.0814 \pm 0.0532$ & $0.1670 \pm 0.1490$ & $0.0254 \pm 0.1020$ & $0.0000 \pm 0.0017$ & $0.0622 \pm 0.0158$ & $0.0042 \pm 0.0078$ \\
\hline Small Mammal burrow & $0.4280 \pm 0.0695$ & $1.6100 \pm 0.2200$ & $0.0404 \pm 0.1280$ & $0.0505 \pm 0.0302$ & $0.6000 \pm 0.1310$ & $0.0974 \pm 0.0407$ \\
\hline \% Above MDC (Average MDC): & $33 \%(0.081)$ & $33 \%(0.19)$ & $0 \%(0.20)$ & $33 \%(0.013)$ & $100 \%(0.011)$ & $33 \%(0.016)$ \\
\hline \multicolumn{7}{|l|}{ Area 5 RWMS } \\
\hline Ant Mound & $-0.0239 \pm 0.0387$ & $-0.0365 \pm 0.0915$ & $0.1090 \pm 0.0891$ & $-0.0075 \pm 0.0054$ & $0.0042 \pm 0.0063$ & $-0.0026 \pm 0.0062$ \\
\hline Small Mammal Burrow \#1 & $0.0094 \pm 0.0494$ & $-0.0887 \pm 0.0788$ & $0.1740 \pm 0.1150$ & $-0.0019 \pm 0.0033$ & $0.0067 \pm 0.0057$ & $-0.0026 \pm 0.0065$ \\
\hline Small Mammal Burrow \#2 & $-0.0035 \pm 0.0327$ & $0.0282 \pm 0.0935$ & $0.0236 \pm 0.0874$ & $-0.0016 \pm 0.0032$ & $0.0106 \pm 0.0058$ & $0.0024 \pm 0.0070$ \\
\hline \% Above MDC (Average MDC): & $0 \%(0.053)$ & $33 \%(0.12)$ & $33 \%(0.12)$ & $0 \%(0.0090)$ & $33 \%(0.0081)$ & $0 \%(0.014)$ \\
\hline \multicolumn{7}{|l|}{ Area 3 RWMS Control } \\
\hline $\begin{array}{r}\text { Composite from } 2 \text { small mammal } \\
\text { burrows and } 1 \text { ant mound }\end{array}$ & $0.6370 \pm 0.0804$ & $0.1410 \pm 0.1280$ & $0.0041 \pm 0.0957$ & $0.0988 \pm 0.0431$ & $6.0300 \pm 0.9780$ & $0.8380 \pm 0.1850$ \\
\hline \% Above MDC (Average MDC): & $100 \%(0.054)$ & $0 \%(0.15)$ & $0 \%(0.17)$ & $100 \%(0.013)$ & $100 \%(0.026)$ & $100 \%(0.021)$ \\
\hline \multicolumn{7}{|l|}{ Area 5 RWMS Control } \\
\hline $\begin{array}{r}\text { Composite from } 2 \text { small mammal } \\
\text { burrows and } 1 \text { ant mound }\end{array}$ & $0.0503 \pm 0.0365$ & $-0.0184 \pm 0.1020$ & $0.1010 \pm 0.1080$ & $0.0010 \pm 0.0020$ & $0.0275 \pm 0.0107$ & $0.0035 \pm 0.0092$ \\
\hline \% Above MDC (Average MDC): & $0 \%(0.070)$ & $0 \%(0.16)$ & $0 \%(0.20)$ & $0 \%(0.0031)$ & $100 \%(0.0030)$ & $0 \%(0.014)$ \\
\hline
\end{tabular}

Green-shaded results are considered detected (results greater than the sample-specific MDC).

(a) \pm 2 standard deviations

(b) picocuries per liter water from sample

(c) picocuries per gram dry weight of sample 
THIS PAGE INTENTIONALLY LEFT BLANK 


\subsection{CONCLUSIONS}

The 2009 environmental and operational monitoring data from the Area 3 and Area 5 RWMSs indicate that these facilities are performing as expected for the long-term isolation of buried waste. Direct radiation exposure data indicate a rate that is well below any dose of concern, and air monitoring data indicate that concentrations of radioactive materials in air remain below any concentrations of concern. Groundwater and vadose zone monitoring data indicate that the groundwater beneath the Area 5 RWMS is unaffected by the waste disposal operations. Soil gas monitoring data at GCD-05 indicate little natural migration of tritium away from the waste at this disposal borehole. Vadose zone monitoring data indicate that vegetation prevents infiltrating precipitation from percolating deep into the soil by returning the moisture to the atmosphere by ET. Long-term vadose zone monitoring data from the weighing lysimeters indicate no drainage through the bottoms of the vegetated lysimeters. Elevated tritium levels in plants and animals sampled from the Area 3 and Area 5 RWMSs show tritium uptake by the biota, but the low levels of other radionuclides do not indicate that there has been biota intrusion into the waste. All 2009 monitoring data indicate that the Area 3 and Area 5 RWMSs are performing within expectations of the model and parameter assumptions for the facility PAs. 
THIS PAGE INTENTIONALLY LEFT BLANK 


\subsection{REFERENCES}

Air Resources Laboratory, Special Operations and Research Division, 2010. Special Operations and Research Web Site. http://www.sord.nv.doe.gov. [Accessed May 27, 2010].

Allen, R. G., I. A. Walter, R.L. Elliot, T. A. Howell, D. Itenfisu, M. E. Jensen, and R. L. Snyder, 2005. The ASCE Standardized Reference Evapotranspiration Equation. American Society of Civil Engineers.

ARL/SORD, see Air Resources Laboratory, Special Operations and Research Division.

Bechtel Nevada, 2006. Characterization Report for the 92-Acre Area of the Area 5 Radioactive Waste Management Site, Nevada Test Site, Nevada. DOE/NV/11718--1154. June 2006.

Bechtel Nevada, 2005a. Site Characterization and Monitoring Data from Area 5 Pilot Wells. DOE/NV/11718--1067. September 2005.

Bechtel Nevada, 2005b. Site Characterization Data from the U-3ax/bl Exploratory Boreholes. DOE/NV/11718--003-Rev1. Bechtel Nevada. August 2005.

Bechtel Nevada, 2005c. Integrated Closure and Monitoring Plan for the Area 3 and Area 5 Radioactive Waste Management Sites at the Nevada Test Site. DOE/NV/11718--449 REV2. June 2005.

Bechtel Nevada, 2003. Nevada Test Site Routine Radiological Environmental Monitoring Plan. DOE/NV/11718--804. Bechtel Nevada. June 2003.

Bechtel Nevada, 2001. Closure Report for Corrective Action Unit 110: Area 3 RWMS U-3ax/bl Disposal Unit, Nevada Test Site, Nevada. DOE/NV/11718--743. June 2001.

Bechtel Nevada, 1998. Hydrogeologic Characterization of the Unsaturated Zone at the Area 3 Radioactive Waste Management Site. Volume 1: "Data Interpretations." Volume 2: "Data." DOE/NV/11718--210. February 1998.

Blout, D. O., W. S. Birchfiel, D. P. Hammermeister, K. A. Zukosky, and K. D. Donnelson, 1995. Site Characterization Data from Area 5 Science Boreholes, NTS, Nye County, Nevada. DOE/NV/11432--170. Reynolds Electrical \& Engineering Co., Inc. February 1995.

BN, see Bechtel Nevada.

Campbell, G. S., 1977. An Introduction to Environmental Biophysics. Heidelberg Science Library. Springer-Verlag, New York.

Cochran, J. R., W. E. Beyeler, D. A. Brosseau, L. H. Brush, T. J. Brown, B. Crowe, S. H. Conrad, P. A. Davis, T. Ehrhorn, T. Feeney, B. Fogleman, D. P. Gallegos, R. Haaker, D. Kalinina, L. L. Price, D. P. Thomas, and S. Wirth, 2001. Compliance Assessment Document for the Transuranic Wastes in the Greater Confinement Disposal Boreholes at the Nevada Test Site. Sandia Report SAND2001-2977. Sandia National Laboratories. September 2001. 
Desotell, L. T., D. B. Hudson, D. Anderson, V. Yucel, G. Shott, G. L. Pyles, and J. T. Carilli, 2007. "Performance of Evapotranspirative Covers under Enhanced Precipitation: Preliminary Data." In: Proceedings of the Waste Management '07 Conference. February 26-March 1, 2007. Tucson, Arizona.

Desotell, L. T., D. B. Hudson, V. Yucel, and J. T. Carilli, 2006. "Use of Long-Term Lysimeter Data in Support of Shallow Land Waste Disposal Cover Design." In: Proceedings of the Waste Management '06 Conference. February 26 to March 2, 2006. Tucson, Arizona.

Doorenbos, J., and W. O. Pruitt, 1977. Guidelines for Predicting Crop Water Requirements. FAO Irrigation and Drainage Paper No. 24, 2d ed. U.N. Food and Agricultural Organization. Rome, Italy.

Levitt, D. G., and V. Yucel. 2002. "Potential Groundwater Recharge and the Effects of Soil Heterogeneity on Flow at Two Radioactive Waste Management Sites at the Nevada Test Site." In: Proceedings of the 2002 International Groundwater Symposium. March 25-28, 2002. Berkeley, California.

Levitt, D. G., M. J. Sully, B. L. Dozier, and C. F. Lohrstorfer, 1999. "Determining the Performance of an Arid Zone Radioactive Waste Site Through Site Characterization, Modeling, and Monitoring." In: Proceedings of the Waste Management '99 Conference. February 28-March 4, 1999. Tucson, Arizona.

National Security Technologies, LLC, 2010. Nevada Test Site 2009 Data Report: Groundwater Monitoring Program, Area 5 Radioactive Waste Management Site. DOE/NV/25946--860. January 2010.

National Security Technologies, LLC, 2009. Nevada Test Site Environmental Report 2008. DOE/NV/25946--790. September 2009.

National Security Technologies, LLC, 2008. Closure Plan for the Area 5 Radioactive Waste Management Site at the Nevada Test Site. DOE/NV/25946--553. September 2008.

National Security Technologies, LLC, 2007. Characterization Report Area 3 Radioactive Waste Management Site Nevada Test Site, Nevada. DOE/NV/25946--080. March 2007.

NSTec, see National Security Technologies, LLC.

Plannerer, H. N., 1996. Siting Criteria for Angle Drilling Under the U-3ah/at Disposal Unit. Los Alamos National Laboratory Report LA-UR-96-1679. May 13, 1996.

Reynolds Electrical \& Engineering Co., Inc., 1993a. Hydrogeologic Data for Existing Excavations at the Area 5 RWMS, Nevada Test Site, Nye County, Nevada. DOE/NV/11432--40. December 1993.

Reynolds Electrical \& Engineering Co., Inc., 1993b. Hydrogeologic Data for Science Trench Boreholes at the Area 5 RWMS, Nevada Test Site, Nye County, Nevada. December 1993.

Shott, G. J., L. E. Barker, S. E. Rawlinson, M. J. Sully, and B. A. Moore, 1998. Performance Assessment for the Area 5 RWMS at the NTS, Nye County, Nevada. Revision 2.1. DOE/NV/11718--176. Bechtel Nevada. January 1998. 
Shott, G. J., V. Yucel, M. J. Sully, L. E. Barker, S. E. Rawlinson, and B. A. Moore, 1997. Performance Assessment/Composite Analysis for the Area 3 RWMS at the NTS, Nye County, Nevada. Revision 2.1. DOE/NV--491-REV 2.1. Bechtel Nevada. September 1997.

Soule, D. A. 2006. Climatology of the Nevada Test Site. Air Resources Laboratory, SORD 2006-03. April 2006.

Snyder, K. E., R. D. Van Remortel, D. L. Gustafson, H. E. Huckins-Gang, J. J. Miller, S. E. Rawlinson, and S. M. Parsons, 1995. Surficial Geology and Landscape Development in Northern Frenchman Flat, Area 5 RWMS, DOE NTS. Interim Summary and Soil Data Report. DOE/NV/25946--466. Raytheon Services Nevada. September 1995.

Tyler, S. W., J. B. Chapman, S. H. Conrad, D. P. Hammermeister, D. O. Blout, J. J. Miller, M. J. Sully, and J. M Ginanni, 1996. "Soil-Water Flux in the Southern Great Basin, United States: Temporal and Spatial Variations Over the Last 120,000 Years." Water Resources Research. Vol. 32, No. 6, pp. 1481-1499.

Warren, R. W., and R. F. Grossman, 2009. Nevada Test Site National Emission Standards for Hazardous Air Pollutants, Calendar Year 2009. DOE/NVI 25946--742. National Security Technologies, LLC. June 2009. 
THIS PAGE INTENTIONALLY LEFT BLANK 


\section{DISTRIBUTION LIST}

$\underline{\text { U.S. Department of Energy }}$

Copies

Jhon T. Carilli

4

LLW Federal Sub-Project Director, Waste Management Project

U.S. Department of Energy

National Nuclear Security Administration

Nevada Site Office

P.O. Box $98518 \mathrm{M} / \mathrm{S} 505$

Las Vegas, NV 89193-8518

E. Frank Di Sanza

1

Federal Project Director, Waste Management Project

U.S. Department of Energy

National Nuclear Security Administration

Nevada Site Office

P.O. Box $98518 \mathrm{M} / \mathrm{S} 505$

Las Vegas, NV 89193-8518

Kenneth M. Small

1

RCRA Program Manager, Waste Management Project

U.S. Department of Energy

National Nuclear Security Administration

Nevada Site Office

P.O. Box 98518 M/S 505

Las Vegas, NV 89193-8518

U.S. Department of Energy

National Nuclear Security Administration

2 (CD)

Nevada Site Office

Public Reading Facility

c/o Nuclear Testing Archive

P.O. Box 98521, M/S 400

Las Vegas, NV 89193-8521

U.S. Department of Energy

National Nuclear Security Administration

1 (CD)

Nevada Site Office

Technical Library

P.O. Box 98518, M/S 505

Las Vegas, NV 89193-8518

U.S. Department of Energy

Office of Scientific and Technical Information

1 digital file

P.O. Box 62

Oak Ridge, TN 37831-0062 
National Security Technologies, LLC

Environmental Management Library

1 digital file

National Security Technologies, LLC

P.O. Box 98518, M/S NLV094

Las Vegas, NV 89193-8521

David B. Hudson

National Security Technologies, LLC

P.O. Box 98521, M/S NLV083

Las Vegas, NV 89193-8521

Theodore J. Redding

National Security Technologies, LLC

P.O. Box 98521, M/S NTS273

Las Vegas, NV 89193-8521

Gregory J. Shott

National Security Technologies, LLC

P.O. Box 98521, M/S NLV083

Las Vegas, NV 89193-8521

Alissa J. Silvas

National Security Technologies, LLC

P.O. Box 98521, M/S NLV022

Las Vegas, NV 89193-8521

Ronald W. Warren

National Security Technologies, LLC

P.O. Box 98521, M/S NTS273

Las Vegas, NV 89193-8521

Vefa Yucel

National Security Technologies, LLC

P.O. Box 98521, M/S NLV083

Las Vegas, NV 89193-8521 